University of Louisville

ThinkIR: The University of Louisville's Institutional Repository

Electronic Theses and Dissertations

1942

\title{
The treatment of adolescence in contemporary American literature.
}

Goldie Mae Fertig

University of Louisville

Follow this and additional works at: https://ir.library.louisville.edu/etd

Part of the American Literature Commons

\section{Recommended Citation}

Fertig, Goldie Mae, "The treatment of adolescence in contemporary American literature." (1942). Electronic Theses and Dissertations. Paper 1787.

https://doi.org/10.18297/etd/1787

This Master's Thesis is brought to you for free and open access by ThinkIR: The University of Louisville's Institutional Repository. It has been accepted for inclusion in Electronic Theses and Dissertations by an authorized administrator of ThinkIR: The University of Louisville's Institutional Repository. This title appears here courtesy of the author, who has retained all other copyrights. For more information, please contact thinkir@louisville.edu. 
UNIVERSITY OF IOUISVIILE

THE TREATMENT OF ADOLESCRMCE

II CONTHMPORARI AMERICAN IITERATURR

\author{
A Disertation \\ submitted to the Faculty \\ of the Graduste Sohool of the University of Ionferille \\ In partial Fulfiliment of the \\ Requiremente for the Degree \\ of Master of Arts
}

Department of Inglish

by

Golde Mae Fort18

Year

1942 
IAME OF STUDENT:

PITLE OF THESIS: THE TREATMENT OF ADOLESCENCE IN CONTEMPORARY LMER ICAI IT TERRATURE

APPROVED BY A READIFG COMITIEE COMPOSED OF THE FOLLOKING MGMBERS:

IANE OF DIRECTOR:

DATE: $\frac{922 n e 1 / 1942}{7}$ 


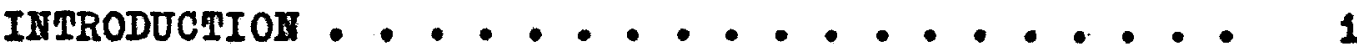
TREA PMENT OF ADOLESCENCE IN:

CHAP TER

I. FIOYD DHLI'S MOE-CAIF . . . . ・

Adolescence in a mid-western tom

II. FRAHCIS SCOTT KEY FITZGERAID'S

THIS SIDE OF PARADISE - . . . - 30

Adolesoence in an eastern prep

school and college

III. THOMAS WOLFE'S LOOK HOMGTARD ANGHT.

Adolesconce in a southern monntain town

IV.

VARDIS FISHER'S II TRAQIC IIFE • • 85 Adolescence on the restern Irontier

V. JAMTS T. FARRBII'S YOUNG IONIGAN AID FATHER AND SOR . . . . . . 111 Adolescence In an Irish Catholio neighborhood of Chicago

\section{CONCLUS IOHS}

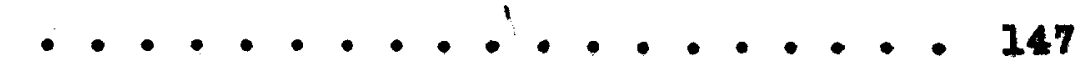

BIBIIOGRAPHY . . . . . . . . . . . . . . 150 APPFNDIX . . . . . . . . . . . . . . . 156

Revier of Iifty-one additional books treating adoleacenoe 


\section{IITRODUCTION}

The scope of fiction treating adolescence in contemporary Ameriesn fiction was found, upon investigation, to be so extensive that it would have been unwise to atterpt to analyze it in its entirets; consequently 1t wes necenery to pat certain limitations upon the range of study. Thus, certain arbitrary exclasions wero made: (1) novele written by any other then Amorican authora; (2) novele witten by women athors; (3) norels about adolescent girls; (4) norels about foreign adolesconta; and (5) norels hering the scene laid in forelgn country oven though written by American authors.

Even with this limitation, it was still nocessary to establish certain standards for selection. Standards adopted were: (1) inclusion only of anthors whose fiction presented serious treatment of adolescence; (2) inclusion of authors representetive of afferent seotions of the country; and (3) inclusion only of anthor: representative of the period between wars.

This aelection automaticallg eliminated (I) anthors of the older generation, ench es Theodore Dreiser, Bdgar Lee Masters, and Sherwood Anderson; (2) books dealing predominantly with childhood on the one hand and with joung manood on the other, wach as Farrell's \pm Eorld I 
Herer Mede and Judgment Dar and Fitzgerald's The Beantifal and the Damed; (3) nostalgia for jouth snoh as Robert T. Coffin's Lost Paradise; (4) sensational episode as is found in Norman IIndsay's Every Mother's Son and in Dan wickenden's two novels The Funning of the Deer and WeIk Itke Nortal; (5) spocialized scone, as Phillip Sterenson' G Gospel Aocording to st. Inte'e and J. T. Foote' Change of Idols; and (6) motery and adventure as Edwin Granberry's ErI King and Idgar Loe Master's Mitch Miller and Kit O'Brien. The application of these standards enabled sifting down of some fifty books to six books by five anthors representative of fivo millens: (1) Floyd Dell (1887), Moon-Calf (1920), adolescence of a M1d-Festern bohomian; (2) Prancis Scott Key Fitzgerald (1896-1940), This Stde of paradise (1921), adolescence of a MAdTestern Prinoetonian; (3) Thomag Wolfe (1900-1938), Iook Homeward Angel (1929), sdoloscence of a southern mountain rebel; (4) Vardis Flaher (1895), In Pragic Iife (1932), adoleacence of a western frontiersman; and (5) Jams T. Farrell (1904), Young Ionigan (1932), adolesoence of an Irish Catholic type-character of a motropOlis; and Father and Son (1940), adolescence of an Iriah Catholio personage of a metropolia. 
The method of disoussion of these authors will be (1) sumary of pertinent facts about the author; (2) comparison of the flctional character with the athor; and (3) a study of the more serious problems of adolescence treated in the flotion, that 18, family. institation, sseciates, and sex.

The method determined the organization of the chapters by individual anthore rather than by topios. These are presented in ohronological order in order to give a sense of the Iiterary movement from 1920 to 2940 as reflected in the trestment of adoleseence. 


\section{CHAPTER I}

FLOYD DHLI' S 10ON-CAIF 


\section{CHAPTER I}

\section{FIOYD DELI'S MOON-CAIT \\ Adolesconce in a Mid-Western Town}

The problem of this chapter is to discuse yoonCalf, 1920, by Floyd Dell, to discover his view of adolescent problems as portrayed by his fiction. MoonCalf is the first of two novels--the sequel is BriaryBush, 1921--in which Dell 8008 on from the problems of chlldhood and youth to those of young manhood.

Ployd Dell wes chosen as a representative of the oarly 1920's along with Francis Scott Key Fitzgerald, bocause both authore give algnificant treatment of adolescence of that period. Dell's treatment is significant becanse it interprets adolescence from a definite point of view--that of a small-town member of the midale olass developing into a Bohemian rebel but coming to look back on his adolescence as that of a moon-calf. The Briary-Bush was omitted in this discussion because it places the emphasis on joung manhood rather than on adolescence.

\section{THE AUTHOR}

The materials available on Floyd Dell are an anonymous article in the Amerioen Bookman, "Floyd Dell, "l

\footnotetext{
1. Anonymons, "Floyd Dell," American Bookman, Maroh, 1923, pp. 65-71.
} 
1923, which presents all the essentiol facts about De11; an autoblography, Homecoming, 2 1933, an elaboration of his norel, Yoon-Calf, which is itself hoarily autoblographical. 3

Dell mored from Barry, Illinois, his home-town, to Darenport, Iowa, where he started his career as a journalist; from there he went to Chicago, where he continued this work; from Chicago he went to New York where he became an editor and an author.

DeIl and George Cram Cook, known to a small group then as a noreliat, became the conters of a small society deroted to art. Dell and Cook had mot in Davenport and for a year or so they were partners on a truek farm. Their vision of living from the farm and writing soon faded; they wore unsuccessful. smong the group around these two was Sherwood Anderson who halls Dell as his discoverer. Other members of the group were Theodore Dreiser on his visits to Chicago, Vachel Iindeay and carl sandburg, jet unknown to fame, and the little Theater Company with its group. The group disintegrated

\footnotetext{
2. HIoyd DeII, Homeooming Tow York: Farrar and Rinehart, 1933), $368 \mathrm{pp}$.

3. See infre, p. 4. A portrait of Dell by Sinclair Lewis, Amorican Bookman, Way 1921, p. 245, ads nothing easential. For further references 80 Frod B. Mllott, Contemporary American Authors (Now York: Harcourt, Brace and Company, 1940).
} 
ag 1 ts mombers loft Chicago.

Dell went from Chioago to Ilow York, bocamo oditor of "The Masses," lived in Greenwich Viliage and produced one-act plays. They were presented by the Iiberal club in the village and were in sense, the means that initiated the little theater movoment in Now York. An offepring of this club was the Washington Square Plagers' organization, whioh gave birth in time to the Provincetown Players and the Theater Gaild. As editor of "The Masses" which opposed the war, he also wote scathing articles published in another soclalist magazine, "The Now Review," attacking German imperialism. He was indicted along with others for oritioleing the government; the speolfic charge was an article defending conseiontions objectors; howerer, whon he himself was drafted, ho did not become a consolentious objector. Dell explains this deviation Irom his course in his autoblography:

Then after The Hasses triel, I was called up as a conscript. I offered no conscientions objections to a war which, as I felt, had now becomo a war against the chief enemy of Soviet Ras8ia, and I was sent to the training camp at Spartanburg, South Carolina. 4

He was payohoanalyzed during 1917 and 1918 and married B. Marle Gage in 1919; his Iirst novel, yoon-Cal1 
Was publishod in 1920.

In 1929 the Meguire Prize for comedy was awarded to Ifttle Acoldent, written by Dell and Whomes Mitcholl. In 1937 he was working on a M.P.A. job in Waghington. Hoon-Calt was his first novel, although he had previously written some pleys and esseys. Since then he has published and edited about iffeen books in adition to short storles and a number of essays and studies. The main 11nes of his life, then are these: (1) he moves from a smell town to the metropolis; (2) he becomes successively journelist, editor, and anthor; (3) he aftiliates with George lram Cook and the Chicago group; (4) he becomes psychoanalyzed and settles down into married iffe.

II. COMPARISON OI FICTIONAI CHARACTER WITH THE AUTHOR According to the anonymous article Moon-calf is antobiographio8l.

His own early life is more or lese given to us in his first novel. He was born, in fact, near Davenport, Iowa, ho did work in a candy fectory, then on a nowspaper--from which he was discharged not for his own short-comings but because the house which the proprietor gave his daughter for a wedding present cost more than the estimate and nocessitated retrenchment--and he did leave Davenport for Chicego, where he obtained a job as a reporter on the "arening POBt."E

b. Lnongrops, op. oft., p. 65 . 
1 comparison of Felix Fay with the anthor bears this out. Felix Fay, the moon-calf, comos from a small wostern town, works as a newspaper reporter, is interested in socialism, writes his first novel liring on a farm--but destroys it--then moves on to become a Chicago Bohemian, gets married and settles down. Mloyd De11, the author, similarly comes from a small western town, works as a reporter on a paper, moves on to Chioago Bohemia, experiments with living on a farm and writing, moves on to Iew York, gets married and settles down. The early scone of Moon-Calf is latd in wostern Illinois; Felix Fay, the hero, spends his childhood in the midalo-west. After the dissolution of the ray family, due to the mother's illness, the hero went to live with his married brother, $\mathrm{E}_{\mathrm{d}}$, in Port Royel, where, at the ond of school, he worked in a candy factory. After Christmas he was laid off and sabsequently obtained employment as a reporter on the "Port Royal Now日." He was discharged from this position because he had used the word "Jer" in an article; his employer was a Jew and objected to the use of the word in his paper. He was rehired on the merits of a human interest story, but discharged later again.

Floyd Dell, the author, was born near Barry, Illinols, 1887. In his jouth ho worked in a candy factory, 
and later became a reporter on now spaper, from which he was discharged because of a tendenoy of the paper to economize.

Felix Fay, the moon-calf, involved in lore affair with Janot Tonet and having a dosire to marry, looked determinediy for another place, without success. Disappointed and desiring to write, he went with Tom Aldon to the latter's farm and remined for a while. Janet, despairing of Felix's Ilnancial success and abllity to marry, accepts a realthier suitor, and Felix, defected, leaves for chlcago.

BRIARY-BUSH continues the story of Pelix' life in Chicago. Here he obtained work first a reporter, then as dramatio oritic for the "Chroniole." The fob was as onbstitute for another oditor, Hewkins, who was away on leave of absonce writing a play. Tho thought of losing his job on Hawkins' return worried him some; also the possibility of going to How York suggested Itself.

- . and what if Hamkins did come back and take away his laurels? There were other jobs in the vorid. If not in Chicego, then--Jes, in New York--

It didn't make any difference what happened. He had boen silly to worry about anything. Roseun was right. One mast Iive fearlessiy . . .6

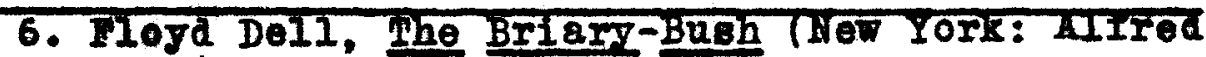
4. Knopf, 1921), p. $26 \overline{2}$. 
Floyd Dell, the author, 11kewise, left Derenport for Chleago where he obtained employment as reporter for the "Broning Post." Later he became oditor of the "Friday Iiterary Reviow" of the "Post."

Other parallel expertences of both hero and author were that both triod living on a farm and writing; both were social misfits, and both became more normal oharacters in leter years.

Felix's farm experience has been mentioned before. His first notel, which ho did not publish, but burnod, -written on the farm--shocked rom Llden's consin as did Bell's Irank and often rude remarks the sooloty of his time.

"Is that nasty young man Pelix Fay really a friend of yours? I think he had better loave port Rojal quick. The story of that horrible ohapter is all over town and - rell, if you knew the things Qloria was saying about him?"

The author similarly did not get along with people. Coming in late to a gathoring of which George Burman poster was host and at which an artist was giring a talk on art, Dell seated himself inconsplcuously noar the door. At the close of the lecture the epeaker offered to answer questions; Dell shocked the guests by asking, "What is the difference between art and apple-butter?" 
It establishod him as rude, insulting, egotistic, anprincipled, and dangerous.

Both the character and the author became less radical later; both married and settled down. After Felix and Rose-Ann made up their quarrel, they dooided to bulld house near the sand dunes; they argued that other poople bullt houses; so why shouldn't they? It 18 said of Dell, the author:

With the pablication of his first norel, MoonCeif, some of his friends were surprised to find no Trace of the ardent rebol, the stringent social critio that they know, in 1ts pages. The rebel, the social critic appears, it is true, in the porson of the hero, Felix Fay--but the novel seemed to be rathor oriticism of him than a justification....

- . the author.. is now enjoying an oldPashioned domesticity at Croton-on-Hudson, with his wife and son, Anthony .. ho is sald to appoar on social ocosions in contentional dinner-elothes.8

Events told in his autoblography which he did not make use of in his fiction are (I) personal contrcts, and (2) psychoanalysis.

Among the persons with whom he came in contret that do not appear in tho novel are the anthors, susan Glespell, Arnold Bennett, Theodore Dreiser, Engene O'llelll, Ioul Ontermejer, Edna Millay, Arthur Davison Flake, Sherwood Anderson, Upton Sinclair, Vachel Iindsay, and Carl Sandburg; oditors, Ilewellyn Jones and Lucian Cary;

$$
\text { 8. Lnonymong, Op. CIt., p. } 70 \text {. }
$$


and socialist Ieader, Margaret sanger.

His psyohoanalysis, presumably, was to ald him in ajusting his sex-1ifo. Diroreed by his wifo after three love affeirs, these were followed by numerous others. Desiring to marry, even before he met B. parie Gage, he sought the aid of a psychoanalyst. About his psjohoanalysis, he says:

Iy paychoanalyet gave mo no interprotation of my dreams, but let mo interpret them myself; nor did he tell me I had terrific mother-complex, and was narcissistic, had a great deal of unconscious homogexuality, and a variety of other frightful-sounding traits; I found all that out myself and told him. He offered mo no advice on my private Iife; it was my own 1des that I should not hare any lore affalra while I was being anslyzod--though this degieion was not oarried out with complete consistency.9

Flotional opisodes not occurring in his real iffe are the IrIondships with Whoels and Rose Hendron. Wheel. represents ang of the older men who were willing to give time and fatherly advice to youths. Rose Hendron was put into the novel at the suggestion of a woman that a girl-character be introduced. She represents an attic aream-girl, a personiflcation of his day-dreams.

In commenting on his norel in his antobiography, Dell oeid that some of the characters were invented, as Whools; Felix Fay was represented as a sensitive, shy, lonely jouth, and not as the aggressive fellow he wae sometimes, partly becanse of faded momory; and his family

$$
\text { 9. De11, Homeoming, p. 206. }
$$


he broke up so as to avold talking about it. As to the identity of the characters, he said that when nobody would be hurt, he merely changed people's names, and described them exactly as they were; but his aweotheart at the end of the book (Jojce Tennant) he disguieed thoroughly, giving her the appearance of B. Marlo Gage, whom he found it pleasure to desoribe.

Conclusions to be drawn on the basis of this comparison are (I) that the fiction is actualig hoavily autoblographical; (2) that Moon-Calf is a frank acoount of the jouth of a mid-western radical; (3) that his radicalism is viered largely as social and psychological malad justment; (4) that his intellectual redicaliem, however, is not so regarded.

This background orres to explain Dell's treatment of the mejor probleme of adolescence.

III. TRRATMENT OF MAJOR PROBLEMS OF ADOLESCENCE

1. Treatment of Family

The treatment of family turns on (1) economic insecurity; (2) indifference to culture; (3) motherdependence. It is a picture of a talented boy outgroming a lower midale-0lass background.

The Immodiate cause of the break-up was the 11 iness of the mother, but this dis ruption seemed the logical climax of a number of factors. The father's 
quarrelsomeness, sternness, and inabllity to got along with people in a business capacity was the forerunner of reduced financial ciroumstances. This in tarn oaused frequent movings which contributed to the instability and restlessness of the members of the family. The finenciel insecurity of the family foreed the wother to take over some of the household duties herself and thus deprive her children of her influence.

They had moved into a large house in the middle of town, and they had a hard-fisted hired girl to holp with the work, but there was more to be done than two women could do. And the children, who had at first shared with her their griefs and hopes and tasks, began to grow up, out of her confidence, out of her life. They let her cook and wash and mend for them but they kept their seerete to thomBelves. They were no longer, in the way they had been, hers.10

The father's aisregard for the finer arts, although the mother, a former school-tescher, favored them, was the predominating influence in the Fey homo. When the children wore small, Mrs. Fay had said they should have a piano. Mr. Fay'g answer was in the form of a hilarious war story; - he was an ex-soldier and delighted in telling boisterous stories--the etory onded in a Yanke' $\mathrm{s}$ using the piano stool to smagh the piano to eplinters.

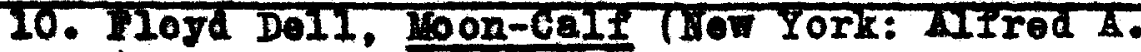
Fnopf, 1980), p. 20 .
} 
Fed played for an hour. I guess, and we all sat absolutely quiet listming to $\mathrm{him}$, and some of tho boys was erying.

And then when he finlshed he got up and swung the piano stool orer his hoad and smeshod that piano to mi thereone!

"Oh! don't!" Bllen cried out, horrifled.

"Tol1," oald Adam, "it rann't mo did it--and anywa, why should we leare it for those robels? There raen't much left of the whole plece when we got through with it."

"But why the piano?"

As a matter of fact, Ldam had been shooked by the destruction of the piano, at such a moment at leset. But he felt obliged to take otrong mascaline attitude on the subject. ho saida.

"A piano's no different from anything else,"

"You wouldn't do such a thing," she llashod.

Ho laughod. "Oh, I don't know about that."

"You wouldn't," she reasgerted, but she was silent all the way home. She returned several times to the subject on succooding days, until he declared thet he was sick of hearing about that "Gol-darn' rebel piano." 11

Ed's talent and desire to paint were nndereloped and were trested indifferently; Felix found the symbols of this frustration hanging on the wall of Ed's house in Port Royal--the ploture of a wounded hawk, falling from the sky and a copy of someone's celebrated painting of Pharoah's horses, two of his former paintinga. 
Because of the allenation of her older chlldren, the mother had wished for a baby to take their place and Felix was the folfillment of this wish. It was possibly dne to the estrangement of the older ch1ldren that she was so solicitons of his welfare, waiting up for him if he were out at night, asking where he was going, whero he went, what he was looking for, etc. Felix resented this maternal amiety. It was this degire to keep him dependent upon her that forced him to wear curls until ho was eight jears old.

of his odd appearance with his belated curls Pelix was utteriy unconscious. He might have worn them forever without protest. But his brothers criticised, his gi ster mocked, and at last when he war elght jears old, and had been chosen to "epeak a piece" at a sohool entertainment, his father sald that the curls mat go. The pioce was "Shoridan's Ride," and his father said that it would look siliy for a boy who looked more 11ke a girl than a boy to sperk it.12

Pelix recelved some of the encoursgement the older children were denled. Bd was working in the mill whon Pelix was child, and the older brother was kind to the Joung one, bringing him pictures which the chlld stored away greedily, pleces of bright-colored woolens, and taking note of progressive signs. Jim, also kind to Felix, contributed his interest. Encouragement was given by all the Iamily excopt 
Ann.

"I can read! I can read!" he cried.

Hardly less exclted than Felix, she [the mother] sat down with him, and he demonstrated the nse of his now magic pover bofore her eyes.

"You shall go to school this fall," sho said, and kissed hin fondry.

Whon his father came home, the demonstration was repeated for his benefit. "You will be going to school before we know 1t," said his fathor, patting Felix's head.

Jim arid he was a little scholar, and that ho would have to learn to keep his face clean when ho went to school.

Ed gave him five pennies.

Only Ann refused to be an audience to his accomplishment. 13

It was generally accepted that Felix wos to get an edacation.

The social status of the family, the middlo-class level, without doubt, Influenced Felix's later life and caveod him to look with displessure on a future a a factory-hand.

He most live in the world of reality. And that moant that ho must go to work. At what? But here realism railod him.

He could not choose between different kinds of worl, becanse he hated them all. He would work at anything. And that meant going to work in some factory. 
He envisaged himself as a factory-hand. He had no illusions about being able to rise from the ranks. He would remain a factory-hand, and an illpaid one. - . Ho sam himself falling in love with some girl at factory; marrying her, having childron, and living in a little house like his brother's just like all the others on both ides of the street up and down the block. His baokjerd could be different if ho manted to plant a garden there, Iike his brother's. His brother's garden was better than any of his nolghbours'. Pelix realized that his garden would be different, too-1t would be the worst garden on the block in which he 11red. It would be worse bocause he would be thinking of poetry instead of potatoos. Ind if he thought of pootry his pay envelope would be too small for hil wife to get along on, and sho would nag him. By that time she would have cossed to be

The uneasiness thet he felt at the dinner in his honor given by Mre. Thomas Alden and sponsored by Helen Raymond, was due to the more elegant surroundinge then those to which he was acoustomed; his ignorance of the use of the cutlery as well as his refusal of saladdressing, because ho did not know what it was, were also due to lack of home-training.

This lack of boing at ease remained with Felix through tho sequel to Moon-Calf, Briary-Buoh; it is menifested in his dislike for meeting ner people, and in his inability to danoe with cortain people, while with other more kindred spirits he could dance enjojably and gracefully. He never became fully at ease in the 14. Ib1d., P. 165. 
practice of social conventions.

2. Preatment of Institutions and Beliefs

Dell'g treatment of institations and beliefo turns on his hero's adoption of a "radical" outlook In place of the conventional one; $1 . \theta .$. (1) rejoction of the Baptist religion in faror of atheism; (2) secular education in socialistic activity; (3) the library and school as a mesne of self-oducation.

Athelom oamo upon Folix rathor suddonly. Ho explained to Stephen Frager that the souroo of it was joining the church. He had caught cold when he was baptized, had been confinod to his home for a month, and had road a book brought to him by the minister refuting the higher critfelsm. He explained as follors:

"It began with my joining the church," he said. "There was a boy at school that I was chumming with--Halter Edwards, Jou know him--and he wanted me to go to Sunday School with him at the Firgt Baptist Charch down here. I wont, and it was rather interesting, 80 I kept on going. Then the Whole elass was going to join church, and they wanted me to join too. I didn't see any reason why I houldn't--80 I ald. Ind I was baptizod, and canght cold, and had to stay at home a month. and the minister came to seo me, and left a book for mo to read. It was a volume of sermons refuting the higher criticiem. I had never heard of the higher eriticism before, but the more I read the more it appealed to me. I read the book three times-and made notes on the margins of the pages as I read. The third time finished mo. I was what the book callod an Infidel. . . And that's all," he finishod.15 
Socialiam had the force of a religion with him. He may have become a convert through his extensive reading--he was introduoed to the works of Robert $G$. Ingereoll by stephen Prazer, and he learned about the extatence of a socialistio party from Margaret, a factory employeo in Vichley; --certeinly his early instability could have influenced his views.

The benefits he derived from his soolalist ootivity were chiefly social and educational, particlpating in the programs and attending the mang social erents of the Togelsanga; also it again brought him in contact with Tom Alden, with whom he had common views and interests.

Al though Felix did not graduato from high school, it played an important part in his Iifo. It focued attention on his literary ability and brought him recognition. \& poem ho was rerlaing was discovered by his history teacher; through him it fell into the hands of Helen Raymond and there followed a period of poetry composition that challenged his talent. A poem of his, "Ballad of the Moors' Expulsion," was accepted for the World's Fair Book, a "mafificent rolume in greon tooled leather," and Felix enjoyed the appreciation acoorded it.

The period of greatest development and most activity for the boy had occurred previously in vichley 
at the Jefferson School. Felix had attracted public attention when he spoke in favor of forming a literary and athlotio club.

But it did not emberrass yelix. For the first time since he hed first come to Jefferson School, he felt t home. He knew all about meetings. He had read H1ll's Manual on the subjoct. So when no one responded to the Principal' invitation to got up and spoak, he rose unabashod and talked five minutes. He spoke of the desirability of forming a permanent organization, to express the spirit of Jofferson Sohool, to enable them to get botter acquainted with each other, and to develop their physical and mental "potentialities." The roomful of boys and girls liatened in awed sllence. They were not aware that Jefferson Sohool had apirit to express, they all, except follx, know each other quite well, they had derelopod painfully and unwillingly 211 the potentialitios they thought they could stand. They only wanted to play baseball and basketb811. Nevertheless, after their first shock of soeing some one do something that wasn't done, namely, get ap and make a peech, they felt conetrained to admire and applaud his nerve.16

He subsequently bocame chairman of a commltteo, president of the organization, engaging in debates and taking part in a play given to raise money for the organization. The dark hour came when a dispute arose as to whether the money should be spent for the library or athletic equipment; the majority deoidod againgt him in favor of athletic equipment and Felix became dejected victim of his organization.

The library was the formative force of relix's early and adolescent life. Going to the library was a 
large part of his recreation and it was also the moans of his acqualntancerhip with Stephen Frazer and Helen Raymond.

It was only when she began to talk of books that his tongue untied itself. He discoursed eloquently of his enthusissms. In pootry--Thon sho had auccoodod in drawing him away from biology and othnology--ho howed ingular gaps in hio reading. He had read 211 of Southey and nothing of Keate! Of Shelley, ho liked best the Masque of Anarchy; the Sensitive plant had bored him, and ho had never finished 1t. He disliked Shakespeare. He had a curlous admiration for Byron's Anglish Bards and Sootoh. Reviewers. He hed never heard of I. B. Yeats; yes, he had, too--only he had supposed the name wae pronounced "Yeete."17

His Intimacy with the library goes back to early childhood. It was after his second year at school that he discovered the Iibrary and began visiting it frequently.

Then one day he picked up on the counter a book Whose pictures interested him; he clung to it, and was reiuctant to take the 0117er Optio book which the librarian had ready for him. The librarian glanced at the book, smiled, and said, "You don't want that book--it's too old for you." -A wicked idea came into Helix's head, and swallowing hard, ho asked, "Could I take it for--for my mother?"

"Oh, certainly," sald the librarian, and gave him both books. After that, Felix carried home two books oach time, one of some standard series for children, and one wildis experimentel choice; the strangest of these cholces was a volame of "Burton's Anatom of Melancholy, and the most fascinating of them "Ies Miserables." 18

In summary, socialism was a philosophy of great

17. Ib1d., p. 176.

18. Ibid., p. 44. 
force in Fellx Fay's life and he remained loyal to its principles through adolescence and young manhood. Atheism, which he professed, plays a less important part in the formation of his ideals. The library is the most educative force in his I1fe, while the school offers the means of self-derelopment.

\section{Treatment of Associates}

His trestmont of associates emphasizes the contacts instrumental to his new oducation. Felix'e male assoelates can be classed into two groups: (I) older men to whom he was attracted, and (2) jouths of his own age. Friendship with both groups was based on common interest; with Tom Alden it was literatare and socialiotic theorles; with Pranz Vogelsang it was socialism; with Wheels it was philosophy; and with the youth Stephen Frazer, it was atheism.

Felix's first meeting with Tom Alden, arranged by Helen Raymond, engendered nothing. Their friendehip began when they met again at a Iree thinkers' meeting, Folix as a reporter for the "Hows" and Tom as an auditor. When Felix suggested the "Monist Society" as a name for the organization, it wes heartily applauded by Tom and their friendahip was renewed. They discovered a matual Iriend in Mrs. Miller, who humorously labelled the new 
sooiety "the Mooniat Society" with them as the chief "Mooniste." Th1s pan may help to explein the title, in part at least. In subsequent visite to Tom's garret room they discussed women, literature, and soolalism. Later, when Felix lost his job on the "News," the two escaped to Tom's farm in the country, each with the intention of writing a novel.

Fellx had introduced himself to Vogelsang after overhearing a conversation between him and another man about socialism. The casual acquaintance became more intimate after contacting each other at the meetings. Vogelsang was a leader in the organization and he managed to have Felix nominated to a programme committeo with Comrade Fmily ROEs, in which capacity Pelix engaged in debates and took part on programa. Vogeleang characterized himself as well as Felix when he criticised some of the latter's poetry.

"That is why," parsaed Comrade Vogelsang, "you have come to me--to be told the truth. Yoa have been mooning about writing verses about ilfe, instead of living. You have been afraid to ilve. Most people are. Something tands betweon them and 11fe. Not only economic conditions: something else-a hadow, a foar. Perhapa it is safer not to try, thoy think. So do you. These poems are your consolations for not living. Thet is why I celled you an old maids' poet. If this young man is oontont with nothing, why shouldn't I be? That is what they think when they read your poems. That is why they like your poems. You have a future--a great future--as a consoler of weak souls. If you just go ahead, you will become famous. But I don't think you will. I don't think you want to be a--n 
"'A pet lamb is a sontimental larce,' " quoted Felix. "Ho, by God, I believe you're right! Go on! 19

Theels, whom Felix had also met by chance, ph1losophises on most subjects and on most occssions. askea.

"I failure also only a mood?" he [Felix]

"There you have it! That is the cheoring ospect or pessimism. Yes, failure is also an illusion... Toll me, what has happened to you?"

"I am under the depressing illusion that I have lost job," gaid Feilx.

Wheols laughed. "A particulariy absurd illusion," he said. "It is imposible to $108 \theta$ your job. You only seom to do so. The fect is that whet we flatteringly call society insists upon our working. It may appear for a moment to relax that demand, but never fear, it will be at yon again. Bven if you try to unfit yourself for work by drink and arugs, it infinite paing to put you in working shape again, and insist upon your performing some of the idiotic motions which conduce to its sense of collective self-respect. I shouldn't wonder if presently society decided to abolish drink altogether, becanse it interferes with work. Hot that $I$ shoula mind! "80

With Stephen Frazer, a fellow high-sohool student one year older than Felix, the common ground for friendship was atheism. They attracted each other'g attention when they found thomelres in a line bofore the library wicket corrying respectively the firgt and second rolumes

$$
\begin{aligned}
& \text { 19. Ib10., p. } 218 . \\
& \text { 20. Ib1d., p. } 262 .
\end{aligned}
$$


of Haeckel's "History of Creation." They found they woro kindred souls. They did not believe in God. They confided how they had come to arrive at thoir views; Stephen recommended Robert G. Ingersoll's books, and those of Maurice Heterlinck, who also ald not believe in God. Felix commended "The Octopus" which deslt effectively with labor and capital. Frequent meotinge in Joe's place followed and manj subjects were discussed; this friendship was interrupted by Felix's remoral to Port Rojal.

Associates offered two ralues to Felix Fay; (I) oducative, and (2) socialistic. Tom Alden proffered his knowledge of literature and scope of reading; stephen Frazer offered his opinions of religion and his reading experience. Franz Vogelsang's contribution was chiefly socialistic but he provided a means of selfdevelopment by being a critic of his poetry and encouraging his participation on programs; Theols' contribution was also of a socialistic nature in the form of conversation and companionshlp. All the men were frank and firm in their views and offered the opportanity for argamentative discussion and encouraged resesrch and self-development.

4. Treatment of sex 
The treatment of sex turns on (1) motherdependence and consequent ferr of momen; (2) his adjastment to conventional marriage.

Felix pay is extremoly interestod in women; ho is making contaots at all stages of his life: The emphatic phases of his attitude toward sox are (I) women 88 a problem to him that he has affeiculty in solving; (2) the return to conventionality of his attitudes toward love and marriage; (3) his interest in women as friend and lover, and the extension of the mother-attrection.

The outstending problem of Felix is to find a girl to whom he can make light lore and who is near enough his own intellectual level to enjoy the sabtle wit of a good play. He tells Tom Alden that his demands would be met if he could find a girl "that can be talked to and that can be kissed. And I want it to be the same girl." He complained that he felt freer with the latter type but that he despised them when they laughed at silly jokes and missed the subtle wit. He adit that he is afraid of girle.

"It's true," he said, thinking aloud. "W attitude is juvenile. Perhapg I am-really--afrald of girls. Of course, erery joung man pretends to be very wioked. So do $I$, when I am with them. I don't know whother they are lying or not. But I am. Porhaps I'm really a Puritan. But I can't holp 
taking those things very seriously. I want real 10ve, and I want a real girl to be in love with." $2 I$

This fear and shyness of women might be traced to h1s oarlier school life when he felt that girls were "a race apart." At the school he attended the girls and boys had separate playgrounds and the "two tribes seldom mixed."

It wight aloo be traced to the family teasinge ho experienced when ho walked home occasionally from sohool with little girl-Iriend. Brolemations Iike, "We1l, Felix 18 growing up. He's got a sweetheart already. I suppose ho'll be staying out late at night, next!" terrifled him. He felt that something more was expected of him; being undecidod what that soming was, he coased his attentions and arolded his would-be companion. Or, it might be traced to an ombarrassing situation when Felix had to sit with a little girl when there was a shortage of seating space in the school. One exception to this fear of women was an attachment to Rose Henderson; perheps this was dre to the unconventionality of their meeting and to the Irank advances made by the girl. She came upon him reading in a garret of a house inhabited by the two families and asked him to

$$
\text { 21. Ibid., p. 294. }
$$


read to her. His embarrassment disappeared, and they became Iriends. Iater they went into the open and into the woods; Felix told stories and she recited for him apeeches from a play taught to her by her mother. Her praise of his story-telling flattered him greatly, and her beautiful play-acting intoxicated him. They discovered they were two people who conld give to esch other things they ralued without being laughed at. His standards for love and marriage were put to a test when be met Joyoe tennant and a mutual love affair reaulted. Joyce enjoged the play--one of his standerds for women--end ho was plessed; her clevermess, however, at aroiding a discusgion of Shaw overshedowed any prejudices he might concoiro against her, and the love affair progressed. That she was above the average intellectually justifies his identification of her with his ideal.

But he refured to be decelved by her enthusiastic enjoyment of the play into regarding her as a fellow adept in the Sharian mysteries. He realized for the Iirst tim how moh heor unintellectual fan there was in a Shan play--and how much plain hearty common sense such as anybody ought to onjoy. He perceived and liked, the spiritual robustness which rose to the call of Shan's humour; but that did not mean that ohe necesserily realized or epproved the ultimate significance ot his ideas. Not that it made any difterenoe:

"Do you think," ho asked, as they lett the theater, "that Shaw overdoes this ider of the man-hanting woman?" 
She laughed lightly. "I suppose not," she gaid and took his arm. "Tet's walk home, if you don't mind. I'd rather." 22

He was not aware of a discrepancy between the live object of his affections and the blurred ideal of his imagination which grew dim and pale in the presence of the "warm reality of the girl."

Fundamentally Felix Fay has very conventional Ideas about love and marriage, although at his first metings with Jojce ho thinks he does not beliere in marriage; he took pains to explain to her his views against marriage. But after their love had reached its climax and they hod surrendered themselves to each other, Felix found his thoory unsatisfactory; he had "secrot qualms of conscience," he felt himself to be "liar and a cheat," and he about-faoed on his own theory in faror of plans for a conventional marriage.

As he stood there in the telephone booth waiting for his number, he realized suddenly that onoe he talked to Joyce, it was all orer but the sotual coremony of marriage; and that they would oommence to plan tonight! He realized it with a rast relief. Of course! What was the use of pretending? They were already married, and their talk tonight would be merely to arrange for a public and coremonial acknowledgment of the fact . . .23

H1 adherence to convention is also rellected in

$$
\begin{aligned}
& \text { 2E. Ibia., p. } 311 . \\
& \text { 23. Ibid., p. } 355 .
\end{aligned}
$$


his Irritation at Jojce's deliberatenese in calling valgarities by their common-place rather than by their scientific name. This tendency goes back to his childhood when at school he resented cosrse telk about girle and aroided sex talk with hauteur. The author tells as that he knew a great deal about sex scientifioally--more than the other children--from an old doctor-book which the femily ormod.

His sex attraction as lover has already been mentioned. His capacity for friendship with women is illustrated in his comradeship with Emily, o cosocialist. Felix thought her agresable and congenial and even at times felt a need for her company. Sometimes he thought he was in love with her, but when ho compared this emotion with the one he had felt in Margaret's presence, he realized it was not love.

The mother-attraction was extended to Helen Reymond, librarian at Port Royal, and to a less degree, in Nr8. Utller, whom he had mot at the home of a Rabbi whom he had interviewed for the "Ners." Helon's interest inspired him to write poetry--he liked to visit her, yet did not dare to do so unless he had something to show her--and gained for him introductions to two Iiterary mon of her aoquaintance--Tom Alden, novelist, and Doyle Clavering, a poet. Clavering helped him to 
complote a poom which was sold to a magazine for twonty dollars while still an adolescent in Port Royal; Tom 4ldon's acqualntano was renowed later.

Mrs. Miler, mor of a flirtatious person than Helen Raymond, attracted and held Felix's interest for a time, but she proved to be more of a casual acqualntance than vital or influential friend.

Women had always constituted an onigma for Felix; he had not solved this problem until he had made ap his quarrel with Rose-Ann, alroady his wife, in Briary-Bush. Bellering himself an unconventional person in regard to Love and marriage, he discovered when put to the test, that he was as conventional as any and beliered in conventional marriage as others did.

\section{SUMMARY}

In conclasion: (1) while Moon-calf is fictional It is heavily autobiographical; (2) it shows the forces that shaped a gifted youth of the lower middle class in the Mid-west before the war: (a) the religious and social outlook of his parents was inadequate for him; ho drifted toward the metropolitan centers; (b) he sought for modern oducation among freo thinkers and socialists; (0) social pressure developed psychological conflicts; (3) the conception of the young radical Bohemian as a moon-calf Indicates the detachment the author had achiered. 


\section{CHAPTRR II}

\section{FRANCIS SCOTT KEY FITZGERAID'S}

THIS SIDE OF PARADISE 
FRANCIS SCOTT KEY FITZGERALD'S THIS SIDE OF PARADIGE

Adolescence in an Bastern Prep School and College

Th1o S1de of Paradise, 1920, by Francis Scott Key Fitzgerald, is aingular treatment of adolescence; it interprets adolescence from the point of view of a mid-Wostern small-town ariatocrat developing into more democratio youth and coming to look on his adolescence as a period of reshaping both in prep sohool and in college.

I. THE AUTHOR

The studies of Fitzgerald by his college companIons John Peale Bishop and Bdmand Wilson and an anonymore article appeared during his lifetime; articles by Malcolm Cowley and John O'Hara after death.l

1. John Peale Blshop, "The Misging II," VIrginie Quarterly Reviow, January, 1937, pp. 107-21.

Bdmund W11son, "Imaginary Convergations, Mr. Van Dyoke Brooks and Mr. Scott Fitzgereld," The Ner Republio, April 30, 1924, pp. 249-254.

Anonymous article, "F. Scott Fitzgerald," American Bookman, March, 1922, pp. 20-25.

Maloolm Cowley, "Of Clocks and Calendars," The Ier Republio, Maroh 17, 1941, p. 376.

John O'Hara, "In Memory of soott Fitzgerald II," The New Republic, March 3, 1941, p. 311. 
Prancis Scott Key Fitzgerald was an exceptionally vain person especially about his age, according to John Poale Blshop. He was fair and blond, anxions to give the impression of being an extensive reader--he was even willing to misrepresent to achieve this impression--with a habit of scribbling, drowsing, and stalling in elass. Acoording to Mr. O'Hara, who wrote of Fitzgerald after he had become an author, ho was not a lorable man but a friendy one. But if you sam him too long at a time he consclously embarrassed you by making jou aware of your ordinarinese. He was an aloot person and Dorothy Parker referred to this characteristic thas--his private hell was so enormous that he really would have gotten little relief from sharing a little of it. 2 He was consclous of passing time and Mr. Cowley characterizes his works as being distinguished by a sense of passing time.

He was haunted by time, as if he wrote in a room lull of clocks and calendars. He liked to begin his paragraphs by stating, "this was the yoar whon..." after which he would tell what everybody wore and said, and sang and how everybody made love in that particular year. He worked hard and patiently to find the exact color of a season that would never be reperted.3

Fitzgerald left Princeton without a degree and bocame second lieutenant in the army during the first

$$
\begin{aligned}
& \text { 2. John O'Hara, op. cit., p. 311. } \\
& \text { 3. Malcolm Cowley, op. cit., p. } 376 .
\end{aligned}
$$


Forld Far. He wrote the Romantic Egoist on week-ends at the officers' club at Fort Leavenworth, Kansas. The revised edition of this novel, This side of paradise, was called the collected works of F. Scott Pitzgerald by T. K. Whipple, a former Princetonian fellow-8 tudent, because not a line of the poems scribbled in lecture halle by the author had been wasted; they had all been included in this novel. 4

Pitzgerald and Hemingway belong to what the press called the Younger Generation; the ones who had seen service in the army. When they returned, it was in revolt against Puritanism. Both Fitzgerald and Hemingway succoeded in commonicating the ir revolutionary attitudes to their contemporaries.

Bdmand Vilson, another schoolmete, presents on imaginary conversation between Van Wycke Brooks and $\mathrm{Mr}$. scott Fitzgerald, in which the latter reads the former letter written by the Younger Generation. It is farcical in content; it starts off congratulating $M$. Brooks on the occasion of the Dial award, then proceede to criticise his various attitudes. It is humorous in that it takes adventage of the occasion to present the views of the Younger Generation to him rather than to get his 
criticism. It is also in keoping with Pitzgerald'a habit of reverting all conversations to himself.

Fitzgerald's novels stress wealth. Bishop

รag6:

Though love is elways in the foreground in the sentimental words of Fitzgerald, no allure is so potent 88 money.

"The rich are not as wo are." So he began one of his early stories. "Ho," Hemingray once said to him, "they have moro money."

This bellef, continualiy destrojed, constantly reasserted, underlies all thet Fitzgerald hes mitten. It mado him peculiarly apt to be the historian of the period.5

This Side of Paradise, 1920, wes the first novel pablished by Fitzgerald. Between 1920 and his death in 1940 he published four novels, five short stories, one plag, and collaborated with Fimund Wilson and John Sohmfalk on two masical comedies.

Summary: (1) Fitzgerald's chief characteristics were egotism and ambition; (2) he developed from snobbishness to a more broadly haman attitude; (3) his education was received at prep school and at college.

II. COMPARISON OF FICTIONAL CHARACTER WITH THE AUTHOR This side of Paradise is obviousig autobiographical. The central character, Amory Blaine spends his early 
childhood in the mid-west, goes east to proparatory school, thonce to Princeton. He leaves college to foin the army where he serres as second lieutenent. After the war ho holds a job as advertising agent, but gives it up and goes beck to Princeton. The author, Scott Fitzgereld, spends his early childhood in the midwost, goes east to preparatory school, thence to Princeton, serres in the army as a second lieutenant, works as an advertising agent after the war, and gives up his job to rewrite his novel. Amory Blaine, the hero of this side of paradise, was born near Lake Geneva, Wisconsin, in the spring of 1896, thus granting him the mid-western background of Fitzgerald himself. He was also of Irish descent, his mother being Beatrice O'Hara; at five he was alroady an agreeable travelling companion for her, a glorious creature beset with real and imeginary frailtios, and whom he addressed by her given name. He attended st. Regis's private school in Connecticut, because some acquaintances he had made in Minnesota were going away to ochool, and the 1dea appealed to him. After finishing St. Regis' he went on to Princeton.

Prancis Scott Key Fitzgerald, the author, was born in st. Paul, Mnnesota, of Irish and Maryland Fnglish 
stock, September 24, 1894. He travelled during his early years with his family, and, due to his inclinations to write rather than to study he was sent to the Howman School in Hackensack, Hew Jersey, in the hope that he would put more time on his studies. Here he became intereated in musical comedy, and it was due largely to this interest that Fitzgerald entered Princeton.

Amory Blaine, the fictional character, attained a prominent place at Princeton, getting a part in the masical comody, "Ha-Ha-Hortonse," which travellod for two weeks at Christmas time, making one of 1 ts stops at Louisfille. He acquired a place on the Princetonian Board, contributed articles to the Nassau Ifterary Magazine, and made a fraternity. The hero failed to make a mathematics credit, and lost his place on the Princetonian board and his chance to be on the senior counail.

. Fitzgerald, the author, entered Princeton in 1913. In his Ireshman year he met John Peale B1shop. The latter says that when they first met, Fitzgerald was about seventeen, although he had lied so often about his age that he would have to refer to his nurse to find ont his exact birth date. Bishop accused Fitzgerald of 
taking eorenteen for his norm; Fitzgerald agreed, excopt that he thought fifteen would be preferable. Blehop said of him that "even then he was determined to bo a genius and since the most obvious characteristic of genins was precocity, he must prodace from an early age. He did, but wanted through vanity to make it even earlier."

Bishop described their first moeting which took place in the Peacook Inn; they talked of books--those Bishop had read, whioh he says were not many, and those Fitzgerald had read, which were even less, and those he said he had read, which were even more. This meoting 18 identical with the fictional meeting botweon Amory Blaine and Tom D'Invilifers:

"Ha! Great stuff!"

The other freshman looked up and Amory registered artificial embarrassment.

"Are you referring to your bacon buns?" H1s cracked, kindly rolce went well with the large spectacles and the impression of a voluminous keenness that he gave.

"Ho," Amory answered. "I war referring to Bernard Shaw." He turned the book around in explanation.

"I've never read any Shaw. I've always meant to." The boy pansed and then continued: "Did you over read Stephen Phillips, or do you like pootry?"

"Yes, indeed," Amory affirmed eqgerly. "I've nover read much of Phililips, though." (He had never hoard of any Phillips excopt the lete David Greham.)

"It's pretty feir, I think. Of course, he's a Viotorian." They sailied into a discassion of pootry, in the course of which they introduced themselves, 
and Amory'a companion proved to be none other than that awful high-brow," Thomas Parke D'Invilliers who signed the passionate 10ve-poems in the lit. - They didn't seem to be noticing, so he Tet himself go, discussed books by the dosens--books he hed read, read about, books he had never heard of, rattling off lists of titles with the facility of'a Brentano's clerk. . .

"Erer read any osoar illde?" ho asked.

"Ho. Who wrote 1 t?"

"It'g a man--don't you know?"

"Oh, surely." A falnt ohord was struok in Amory's momory. "Fann't the comio opera, 'Patience,' written about himp"

"Yes, thet's the fella. I've just finished a book of his, 'The Pleture of Dorian Gray,' and I certainly wish you'd read it. You'd like it. You can borrow it if you want to."

"Why, I'd Iike it a lot--thanks." 6

The author, like the fietional character, was

aropped from class in his Ireshman year; es Bishop puts 1t, "Iike so many preooclous literary talents, he, I

belleve, had a tendency tomard tuberculosis."7 Fitsgerald got into things in Princeton. He had a hand in threo productions of the Triangle Club, collaborating on a Iibretto with Edmund Wilson, and once acting as a chorus girl in show. He contributed stories and poems to the Princetonian Tiger and to the Nassen Iiterary Magazine,

6. Mrancis Scott Key fitagerald, This Side of
Paradise (New York: Charles Scribner's Sone, 1920), p. 55. 7. Bishop, op. e1t., p. 109 . 
and was a nember of the editorial board of each. Heither hero nor anthor graduated. Both left college to join the armo, and both became lieutenants. Fitzgerald did not go abroad. He spent his weok-onds writing novel, The Romantic Egolst, which featured some of the Princetonian group, but which did not succeed In being pablishod. After the war was orer both the character and the author held poorly peid jobs as advertising writers. Fitzgerald left his job in 1920 whon he had sold a story for thirty dollars, and went home to rewrite his novel. In two monthe ho had finished lihis side of Paradise, which was highly successful. With the enccess of this novel, his deys of struggle were orer. Blaine, the hero, Ilkew1se gave up his fob as advertising writer, and the novel leaves him, hitch-hiking towerd Princeton from New York, with only twenty-four dollars in his pocket.

From this comparison the following concluaiona can be drawn: (1) This S1do of paradise is largely antobiographical; (2) that it is a romantic account of a midwestern Princetonian; (3) that romanticiom is viewed largely as a tendenoy to project himself into the vealthy class. 
III. TRRATMRENT OP MAJOR PROBIEUS OF ADOLESCENCE

1. Treatment of Family

In contrast to the other authors, Pitzgersld's

treatment of family is limited to mother and son. This treatment differs from that of the other authors discussed in that their treatment is of the youth in relation to other members of the family as well. The mother-son relationship is presented from threo points of View: (1) characteriatics of the mother; (2) the mother' 1 influence on the son; (3) the emancipation of the son.

Amory Blaine's mother was a very wealthy, selfindulgent, pampered women. The author tells us that as a young lady she was of an exceptionally weal thy family, had delicate features, and showed good taste in aress. She had obtained a brilliant education abroad, was known in high social ana religious Roman circles as fabulously weal thy Americen girl, had travelled in Europe, viaiting Fngland and Anstria and had obtained a rast knowledge of arts and traditions "barren of all 1deas." She was critical of ex-western American romen, complaining to Amory that "they had accente--not southern nor Boston, nor accents attached to any particular locality; just acconts." 
She boasted to Amory that doctors had told her that if any man had done the conglstent drinking that she had, he would be completely shattered and long since dead. In regard to religi on she professed Catholleism, bat having discorered that prieste were more attentive to and interested in those who were in process of losing Paith, she posed as the latter type.

Though she thought of her body as a mass of frailties, she considered her soul quite as ill, and theretiore important in ber 1ife. She had once been a Catholic, but discovering that priesta were infinitely more attentive when she was in process of losing or regaining faith in Mother Church, she maintained an enchantingly wavering attitude. Often she deplored the bourgeois quality of the American Catholic clergy, and was quite sure that had she lived in the shadow of the great Continental cathedrals her soul would still be a thin flame on the mighty altar of Rome. Still, next to doctora, priests were her farorite sport. 8

The author tells as that at IIfe Amory was already

a delightiul companion for her. Some ot her selt-

indulgence is bestoved apon her son.

"Dear, don't think of getting out of bed yet. I've always suspected that early rising in lite makes one nerrous. Clothilde is having jour breakIast brought up."

"All right."

"I'm feeling very old to-dey, Amory," she would eigh, her face a rare cameo of pathos, her voice exquisitely modulated, her hands as facile as Bernhardt's. "My nerves are on edge--on edge. We 
must leave this terrifying place tomorror and go soarching for sunshine."

Amory's penetrating green ejes would look out through tangled hair at his mother. Bven at this age he had no illusions about her.

"Amory."

"Oh, yes."

"I want you to take a red-hot bath--as hot as you can bear it, and just relax your nerves. You can read in the tub if you wish." 9

Hor egotism, posing, and flare for forelgn airs

is reflected in the son when he rehearses his entrance into the parlor of Myra st. Claire, who has invited him on a bobbing perty, while he is in Minneapolis visiting

his uncle. He would be late, of course, since he thought

his mother would favor it.

He would cross the floor, not too hastily, to Mrs. St. Claire, and say with exactly the correct modulation:

"My dear Mrs. St. Claire, I'm Irightfuliy sorry to be late, but my mald--he paused here and realized he would be quoting--but my uncle and I had to see fella--Yes, I've met jour enchenting danghter at dancing-sohool."

Then he rould shake hands, using that slight, half-foreign bow, with all the starohy little females, and nod to fellas who would bo standing 'round, paralyzed into rigid groups for mutual protection. 10

His egotism and consciousness of clothes are

9. Ibid., p. 5 .

10. Ib1d., p. 10. 
desoribed as he returns home from Minneapolis. He was wearing his first pair of long trousers, set off by a purple accordion tie, parple socks, and a handkerchief, edged with purple, protruding from his pocket. The strikingness of their appearance caused his mother to speak of them as a "get" and ask if his underwear Tere purple also.

The emanoipation of Amory is effected in part by St. Regis's preparatory school, and completed by Princeton Univeraity. Then Amory entered st. Regis's ho is explained as being a composite of Amory plus Beatrice. Again he did a great deal of posing and was not well I1ked; but by the time he left st. Regis's, the author tells us, Beatrice had been drilled out of him, and he had become St. Regis plus Amory.

From the scoffing superiority of sixth-form year and success Amory looked back with cynicol wonder on his stetus of the year betiore. He was changed as completely as Amory Blalne could over be changed. Amory plus Beatrice plus two years In Minneapolis--these had been his ingredients when he entered st. Regis'. But the Minneapolis jears were not a thick enough overlay to conceal the "Amory plus Beatrice" from the ferreting eyes of a boarding-school, so St. Regis' had very painfully drilled Beatrice out of him, and begun to lay down new and more conventional planking on the fundamental Amory. But both St. Ragis' and Amory were unconscious of the fact that this fundamental Amory had not in himself changed.1I 
By the time he had entered Princeton, he had become completely emanclpatod from his mother. Hia egotism, nevertheless, persisted, and as ho mast be in the limelight, ho set about to accomplish this; ho decided to be one of the gods of his class.

During his college career, Monsignor D'Arey,

Iriond of his mother's had replaoed Beatrice and his influence eroked self-criticism in the youth. Confidences were exchanged between the two, and the older man holped the younger in self-analysis.

Amory talked; he went thoroughly into the destruction of his egotistic highways, and in a half-hour the listless quality had left his voloe.

"What would you do if you left college?" asked Monsignor.

"Don't know. I'd like to travel, but of course this tiresome wer prevents that. Anyways, mother would hate not having mo graduato. I'm just at sea. Kerry Holiday wants me to go over -ith him and join the Lafayette Isquadrilie."

"You know you wouldn't like to go."

"Sometimes I would--to-night I'a go in a second."

"Well, you'd have to be very mach more tired of life than I think you are. I know jou."

"I'm afraid you do," agread Amory reluotantly. "It just seemed an easy way out of everything when I think of another nseless draggy year."ile 
The mother had passed on her snobbishness, impatience, posing, egocentricity to her son, to the extent that he was generally intolerable among other youths. His associations at sohool had stripped him of his undosirable characteristics and had fashioned him into a person more apt to make friends at college. At college, family had dropped completely into the beokground and had boon replaced by the influonoe of the school, the assoc1stes, and of the Catholic olergyman, Monsignor D'Aroy.

2. Treatment of Insti tutions

The treatment of institutions is limited to the two sohoole, St. Regig' Preparatory ochool and Prinooton Colloge. Religlous adherence, al though only elightly alluded to, is omphasiad by the friendehlp between Amory and the Cathol1c prelate, Monsignor D'Aroy. The importanoe of the influence of St. Regis' school is that it made him aware of his defocta and bogan the emancipation from his mothor. Amory's attitude toward St. Regis' was lackadaisical and he took only superficial interost in his mork. This fact is borne out by the small amount of space given to ita discuseton in comparison with the number of pages many timos as great devoted to the 
discussion of progress at Princeton.

The Influence of St. Regis' can be summed up

best by the author's statement at the time of his

ontrance to this sohool.

Amory'g two years at st. Regis', though in turn painful and triumphant, had as little real significance in hls own life as the Amerioan "prep" school, crushed as it is under the heel of the universities, has to American 11 fe in general. We have no Eton to create the self-consciousness of a gorerning olass; we have instead, clean, flacola and innoonous preparatory schools.13

And again:

Yoars afterward, whon he went back to st. Regig', he seemed to have forgotten the successes of sixthform year, and to be able to ploture himself only as the unadjustable boy who had hurried down corridors, jeered at by his rabid contemporaries med with common sense.14

In contrast to this, his years at princoton are filled with activity, companionshlp, succosses and failures. In his freshmen year he decides that he mugt be among the leaders. Calculating shrowdness, egotism, and ambition are reflected in his evaluating the organizations to which he preferred to belong. He decided that writing for the Nassau Iiterary Magazine would get him nothing but being on the Deily Prinoetonion would get any one a great deal. He submerged his desire to 13. IbIa., p. 29. 14. Ibid., p. 40 . 
set with the English Dramatic Association when he found that ingenaity and talent concentrated in the Triangle Club, an organization which took an extensive Christmas trip each Jear. His attitude toward the student body is summarized here:

"Wo'ro the dermod midalo class, thet's whet!" ho complainod to Kerry ono day as he lay otretchod out on the sofa, consuming a family of Fatimas with contemplative preciaion.

Well, why not? We came to Princeton 80 we covld feel that way toward the amall collegea-here it on 'om, more self-confidence, dress better, cut a swathe--n

"Oh, it isn't that I mind the glittering caste system," admitted Amory. "I like a bunch of hot oats on top, but gosh, Eerry, I've got to be one of them."

"But jast now, Amory, jou're only a sweaty bourge018."

Amory lay for a moment without sporking.

"I won't be--long," he said finally. "But I hate to get anywhere by working for it. I'll show the marks, don't you know." 15

Amory's ogotism and vanity wore gratified whon he obtained a plece on the Prinoetonian during his sophomore yoar and fell into the ceste of "Ha-He-Hortense!" as Bolling 0il, a private lieutenant. He thought afterward of sophomore spring as the happiest time of his lifo. His social life was enviable with his Iriendships, with 
occasional auto trips to New York and other near-by places, and with participation in Iraternity activities. These successes suddenly reversed and his inflation collapsed when he falled to make a mathematics crodit and lost some of the places of honor he had won.

"No--I'm through--as far as ever being a power in college is concernod."

"But, Amory, honestly, what makes me the angriest isn't the fact that you won't be chairman of the Prince and on the Senlor Counc1l, but jast that you didn't get down and pass that exam!"

"Not me," said Amory slowly; "I'm mad at the concrete thing. My ow idleness was quite in accord with system, but the lack broke."

"Your system broke, you mean."

"Maybe."

"Well, what are you going to do? Get a better one quick, or just bum around for two more years as a has-be日n?"

"I don't know yet. . . "16

That he was not devoid of religious attachment or sentiment is evidenced by his friendship with Monsignor D'Arcy. Humerous visits to the older clergyman, frequent and lengthy correspondence, exchanges of confidences and ideas, 211 hint at a fundamental religious tendency. Their close relation is expressed in a letter dated January, 1918, and written by the Honsignor to the youth, 
then second lieutenant in the 17lst Infantry, Port of mbarkation, Camp Wil16, Long Island.

Amory, I've discovered suddenly that I'm an old mBn. Like all old men, I've had dreams sometimes and I'm going to teli you of them. I've onfoyed imagining that jou were my son, that perhaps when I was joung I went into a state of coma and begat you, and when I came to, had no recollection of it. . . it's the patermal instinct, Ampry--celibacy goos deeper than the

The priest's death made Amory aware of the clergyman's importance to poople--their trust in his falth, in his chooriulnoss, in his attitude toward religion, and in his dependability. This contemplation made him aware of his own grest desire which he had hitherto not recognized-to be necessary to people.

Amory's sojoum at St. Regis' made him more likeable and prepared him for a more satisfactory and successIul career at Princeton. At Princeton his ambition and talents won him enviable pleces of honor; but in common With the frivolous youth of the "Younger Generation," with which the author is identifled, he throw away these honora rather than apply himself to study to remove the mathematics condition negligence had brought upon him. The self-indulgence of the mother still persists with him; as long as honors are won with little or no 
effort, he accepts them and becomes a part of the glittering world; but as soon as an obstacle is encountered that requires perseverance to overcome, he swerves and suffers defert and finds it necoseary to change the course of his life. The problem here encountered is a direot result of his early pampering and indulgence.

\section{Trastment of Associates}

Apart from Monalgnor, Amory Blaine's associatos are school associates; those of St. Regis' and those of Princeton. Amory Blaine had few or no associates during his early years. His mother was his closest companion, with the exception of a fow acquaintances mede in Minneapolis when he visited his uncle; these contacts were only superficial.

At. St. Regie' he again mede fow friends. His approaches were not such as to conduce friendship.

He went all wrong at the start, was genersily considered both conceited and arrogant, and aniversally deteated. He played football intensely, alternating a reckless briliency with a tendency to keop himself as safe from hazard as decenoy wovld permit. In a wild panic he backed out of a Iight with a boy his own size, to a chorus of scorn, and a week later, in desperation, picked battle with another boy very muoh bigeer, from which he emerged badly beaten, but rather proud of himself.18

\section{Ibid., p. 30 .}


His unpopularity was emphasized by a conference to which Mr. Margotson, a professor, summoned him on the last night of his first term. The professor was about to explain the cause of his unpopularity whon Amory interrupted:

"I know--oh, don't you a'pose I know." His voloe rose. "I know what they think: do you s'pose you have to tell me!" He paused. "I'm--I've got to go back now--hope I'm not rude--"

He left the room hurriedly. In the cool air outeide, 88 he walked to his house, he exulted in his refusal to be helped.

"That dam old fool!" ho cried wildly. "As if I didn't know!"lg

The schooling at st. Regis' presented Amory's IIrst close contacts outside his own family. It was to be expected that he would have trouble; but the drilling having been thorough, he was botter prepared for new start at Princeton. At Princeton his difficulties with Iriendship disappoared, and he began making friends immediately. His associates at Princeton are discussed as to (1) their identities; (2) their activities; their influence. His first friends at Princeton were the Holiday brothers, Burne and Kerry. They often expressed their innermost thoughts to each other. 
"I can't drift--I want to be interested. I want to pull strings, even for somebody else, or be Prinoetonian chairman or Triangle president. I want to be admirod, Kerrg!"

"You're thinking too mach about yourself."

Amory sat up at this. "Ho. I'm thinking about you, too. We've got to get out and $m i x$ around the class right nov, when it's fun to be snob. I'd like to bring a sardine to the prom in June, for instance, but I wouldn't do it anless I could be dam debonaire about it--introduce her to all the prize parlor-gnakes, and the footbali captain, and all that simple stafi."

"Amory," said Korry impatiently, "you'ro just going around in a oircle. If you want to be prominent, get out and try for something; if you don't, just take it easy." He yamed. "Come on, let's let the smoke drift off'. Wo'll go down and watch football practice."20

Amory'g introduction into the higher and more exclusive circles bogan with his friendship with Tom D'Invililers. It wes during the second half of his first year that he met "that awful highbrow, Thomas Parke D'Invilliers," who wrote passionate love pooms for the "Lit."

Tom D'Invilifiers became at first an oocasion rather than a friend. Amory sat him about once a week, and together they gilded the coiling of Tom's room and docorated the walls with imitation tapestry, bought at an auction; tall candlesticks and Iigared curtains. Amory liked him for being clever and literary without effeminacy or affectation. In fact, Amory did most of the strutting and tried painfuliy to make every remark an epigram than which, if one is content with ostensible opigrams, there are many leats harder.21

20. IbIa., p. 52.

21. Ibid., p. 57 . 
Another frlend of no little import was attracted at this time, Alex Connage. Alex was a friend of both Tom and Amory. These three shered an apartment after the war, and 1t was while he was with them that he had his serious love affair with Roselind, Alec's sister; worked an advertising writer, and began his careor as a writer.

The activities of these college sesociates were those common to any college; fraternity danoes, weok-end trips, discussions on various oubjects, and participation in various clubs. On one trip, taken with all of them pemiless, it was remarkable how they manoeurred to eat, cloep, and attend mories, without paying. On another woek-ond trip to Nor York an eccident occurred in whioh one of their companions, Dick Humbert, was killed.

Their activitios wore variod:

Mostly there were parties--to Orange or the shore, more rarely to New York and Philadelphia, though one night they marshallod fourteon waitresses out of Childs' and took them to ride down Fifth stenue on top of an auto bus. They all cut more olasses than wore allowed, which moant an additional course the following yoar, but apring was too rare to lot anything interfere with their colorful ramblings. In May Amory was oleoted to the Sophomore Prom Cormittee, and when after a long ovoning's discussion with they made out tentative $118 t$ of class probabilities for the Senior Council, they placed themselves among the surest.22 
Their discuseions were sometimes personel, and sometimes on such subjects as snobbery of fraternities, religion, 11terature, or writers.

Iate hours and gambling proved to be Amory"s downfall; they were the cause of his failure at the end of his sophomore gear.

Tom D'Invililers and Amory walked late in those days. A gambling fever swapt through the sophomore class and they bent over the bones till three $0^{\prime}$ clock many a sultry night. After one session they came out of Sloane's room to find the dew falion and the stars old in the sky.

"Iet's borrow bicjeles and take a ride," Amory suggested.

"All right. I'm not a bit tired and this is olmost the last night of the year, really, because the prom stuff otarts Monday."

They found two unlocked bicjcles in Holder court and rode out obout half-past three along the Iewrencevilite Road.2z

At Princeton his associates are more numerous and more exclusive; they belong to the leaders and to the wealthiest families. With their backing and his own talents he is swopt to high offices; also through them and their indiacretion in gambling late hours he 10808 his prestige and must noeds revise his course of progress.

When the 1s over, the three friends, Alex Connage, Tom D'Invilliers, and Amory share an apartmont 
in Hew York. After his disappointing love affalr, when he has thrown over his job, is prectically penni108s, and is undocided about his future, the friends break apart--for various superficial roasons-and Amory, alone, leaves Hew York Ior Princeton.

\section{Treatment of Sex}

Amory saw girls doing things that oren in his memory would heve been impossible: eating threeo'clock, after-dance sappers in impossible cafes, talking of every side of life with an air half of earnestness, half of mockery, jet with a furtive excitement that Amory considered stood for a real moral let-down. But he never realized how widesproed it was until he sew the citles between Her York and Chicago as one vast jurenile intrigre.24

The sex experiences of Amory Blaine ere discussed with reserve. H1s associations with women range from the superlative degree of sublime love through Priendshipe to drunken brawls with women companions.

His most serious lore affair was inspired by Rosalind Connage, sister of Alex Connage. Iore was immedate and mutual; it lasted about five weeks. In apite of the passionate declarations between the lovers, Rosalind was persuaded by her mother to look at the marial side of marriage. She finally agreed with her mother that Dewson Ryder, wealthier than Amory, would make her the better husband. Amory engaged in a throe 
Feoks' alcoholic spres which wore him out emotionally. The author tells us that Amory had subsequent love affaire, bat none of them had the vehemence and pasaion of this one.

His relations with Isabelle Borge, Clara Page, and Eloanor Ramily are in the nature of more serions friendships. Isabelle, a buttertly type, had fired Amorg's Imagination to the extent that he stayed over a day longer on his Christma vecation to renew his. acqualntance with her. Their frlendehip grow into young 10ve. This emotion was intensifled by Isabello's attending a dance at Princoton as Amory's gaest. The thunderbolt came whon Amory's stud made red place on Isabelle's neok while he was kiseing her--on a visit to her home. This started a series of quarrels that ended in Amory's departare the next morning before the Borge framily had risen.

Clare Page, a third cousin and a widow living in Philadelphia, was an exact opposite to Irabelle. Sho was domestically inclined, settled, and more matare. Amory proposed to her; she retused him, declaring she wanted to gave herselt wholly for her two children. She assured him that he did not love her, and he agreod that the ceuse of his emotion was the moonlight.

With Eleanor Ramilly the reaction was responsive 
Iriendship rather than 10ve. Amory met Eleanor dramatiosly, taking shelter from a storm in load of hay, while he was visiting his ant. They swam, rode, conversed, and played together during aumer. Thelr last night was punctuated by a dramatic climax when Eleanor deolared she was going to jump her horse over a cliff, turned, rode madly for it, then tumbled off as the beast leapt over the brink, deatroying itself.

A soandal occurred in connection with 1 lex. Connage involving Amory. In this episode he played the oacrifloing friend, taking the rap that Alec was ontitled to teike. Amory, Alex, and Jill, friend of Aleo's, took rooms at a hotel in Atlantic City. Faced with a surprise visit of the house detectives, Amory made slex pose as beling dead drunk, assumed the responsibility of having Jill as his companion and admitted the detectives. He got off without suffering any of the consequenoes of the Mann Lot but with a promise of unpleseant publicity. True to promise, atatement of his disgrece appeared in the newspaper simultaneously with the announcement that Rosalind Connage was to be married to $\mathrm{Mr}$. J. Dawson Ryder, of Hartford, Connecticut. In comparigon with the experiences of Vridar Hunter or of Stude Lonigan, Amory Blaine's sex experiences are presented with propriety and reserve. 
IV. SUMMARY

Fitzgerald's This S1de of Paradise (1) is largoly autobiographical; (2) it shows the forces that shaped gifted youth of the wealthier class in the midrest before, during, and after the war; (a) there is less interest in religion then in sociel and educational accomplishmont and in association with influential people; (b) tho more wholesome goal of adolescence is a democratic attitude. 


\section{CHAPTER III}

THOKAS WOLFE'S IOOK HOMETARD ANGEL 
THOMAS WOLFE'S LOOK HOMRHARD ANGET Adolosoence in s Southorn Mountain Town

The problem of this chapter is to discuss the adolescent problems portrajed by Thomas Clayton wolfe in his novel, Look Homeward Angel, 1929. The sequel to this novel, of Time and the River, 1935, 8000 on from the problems of ohildhood and youth to those of young manhood and is therefore omitted.

Among the writers of the late 1920'8 Thomas Wolfe offers a significant treatment of adolescenoe. It is a romantic treatment of jouth in violent reaction against life in a boarding-house in a southern mountain town.

The prinoipal materials available for the life of the author are number of articlesl and his own

I. Hamiton Basso, "Thomas Wolle, a Portralt," The New Republic, June 24, 1936, pp. 199-202.

Jorienathen Daniels, "Thoma Wolfo," Saturday Reriow of Iiteratare, September 24, 1938, p. 8 . March 9, 1935, pp. $68-70$. Clifton Fadiman, "Thomes Wolfe," New Yarker,

Camille J. MoCole, "Thomas Wolfe Embraces IIfo," Cathol10 Worla, April 1936, pp. 42-48.

Thurston Mocauley, "Thoma Wolfe, Triter's Problems, Publisher's Woekly, Decomber 24, 1938, pp. 2150-2158. 
antobiographioal account of his writing of his first norel and of 1 ts reception. 2

The section on the author is omitted in this chapter because (1) the materiala are more concernod with the anthor's works than with his 1ife; (2) in contrast to the writers whose fiction omits mach that is known about their lives, Wolfe's Iook Homeward Angel nearly covers his. For this reason it does not seem necessary to present the outline of his life separately.

I. COMPARISON OF IICTIONAI CHARACTER VITH THE AUTHOR

The preface "To the Reader" of Iook Homeward Angel establishes it as autobiographioal:

This is a first book, and in it the author has writton of experience which is now far and lost. but wich was once part of the fabric of his 11 fo.

Robert Ponn warren, "A lote on the Hamet ot Thomas Wolfe," American Review, Hay 1935, pp. 191-208. John Donald Fede, "Prodigal," Southern Revion, July 1985. pp. 198-198.

George Stephens, "Always Looking Homeward," Saturdar Revier of Iiterature, June 24, 1939, pp. 5-6.

Ann Preston Bridgers, "Thomar Folfe, Legends of a Man's Hunger in his Youth," Saturday Review of Iiterature, Apri1 6, 1935, pp. 599-609.

Brmest Sutherland Bates, "Thomas Wolfe," Inglish Jonrnal. September 1937, pp. 519-527.

2. See infra, p. 65 . 
If any reader, therefore, should sey that the book is "autoblographical," the writer has no anewer for him; it seoms to him that all serious work in fiction is autobiographical--that, for instance, more autoblographioal work than "Gulliver's Travelo" oannot easily be imagined. 3

But Look Homeward Angel is more directig autobiographlcal than Gulliver's Travels, as Wolfo saw at the time he wrote You Can't Go Home Again. Hugeno Gant, fictional horo, grows up in Altamont, Catamba, attends state university, graduates, attends Harrard, teashes at the New York University, visits Europe, returns to his position and publishes his first.novel. Thomas Wolfe, the author, grows up in Asherille, North Carolina, attends the state unirersity, thon Harvard, teaches at the Univeraity of New York, visits Europe, writes his first novel, and returns to the United States and pablishes it.

Inagene Gant, the hero, was born in Altamont, Catamba. He is the son of W. 0. Gant, a native pennoglvanian and a wanderer for many jears. He is none other than Folfe's Iather; and El1za, from the native pentlands family is none other than the mother.

Thomas Clayton wolfe was born on october 3, 1900 , at Ashorilie, North Carolina. His father was William

3. Thomas Wolfe, Look Homeward Angel (Now York: The Hodern Ilbrary, 1929T. 
Oliver Holfe, a native Pennsylranian, who had learned the craft of stone-outter in Baltimore. He had roamed restlessly over the country for many jears, drifting finally to lahevilie, where he set up a shop. He was a man of great physical strength and of extravagant appetites. In time he married JuIia Elizaboth Wostall of a family native to that section for several generations.

Thugene Gent, the central character, spent his childhood and youth at Altamont, which is nono other than Ashorilie. The child and youth, though uncomplaining, did not show signs of happiness. He had some companions with whom he played, but this aspect of his Iffe was negligible. The friendly separation of his parents, Gant staying at home and Eliza taking over Dixieland, constituted a problem for him. Being the youngest he was taken to Dixieland with Bliza, although he preferred his Iather's home and spent much time there. Belng Forced to sell the Saturday Evening Post, because of Iuke's ambition and saccess, was distasteful to him and hurt his pride.

Thomas Wolfe, the author, grew up at Asherille. H1s jouth was not a happy one; incessent atruggle between his strong-willed parents made his home-life unsettled, and his brothers and sisters hod littlo use for him. 
Hamilton Basso states in his articlo:

"I guess the only real sympathy and understanding I had during this period of my life," he said one evening, "came from my brother Ben." Thia brother, of course, is the Ben Gent of the novels; the Benjamin Harrison Wolfe to whose memory is dedicated the book of shorter pieces, "From Death to Morning." 4

In the novel, Mrs. Gant conducted a boardinghouse at Dixieland for tourists. She often oxhorted Eugene "to drum up trade," which he resented. The boarders here answered most every description--insane people, tuberculars, drinkers, adventuresses, and a pregnant woman sesting escape from her own communtty; this motley crowd caused Helen to wonder where her mother got them all.

Mrs. Wolfe aleo opened a boarding-house for tourists of more moderate means; these guests were drab, futile, and empty. Tom ran errands betore and atter school and helped around the house. School offered him no more escape than his home. His school-mates thought him queer, as did his brothers and sisters. Hemilton Basso says :

They find it difficult today to find he has become an important American writer. I met one of his sohool-mates in Asheville. "We all thought Tom was cuckog," he said. "I can't get over h1s oncoess." "I5"
4. Bas80, ㅇ․ c1t., p. 199 .
5. Basso, 10c. eit. 
Tom Wolfo found his escape in books, in the world of pootry and Ideas. His father had a tas to for literature and passed this heritage on to his son.

Fugene Gant, the hero was ready for college before he was alxteen; he ontered State University. Here he read a great deal; he kept up his required reading in Englioh, but outside of thet, he read what he pleased. He held himself aloof to a great extent from essociates, but during his last yoar he gained some prominence. He received his A. B. degree, W. 0 . and Eliza attending his graduation. At the ond of the suoceding summer he announoed his intention of attendIng Harvard. After an unpleasant home scene, he bade his mother good-bye and left for the east. Tom, the author, was also ready for college when he was fifteen. He ontered the University of North Caroline, where, after four years, he obtained his A. B. degree. At college he was editor of the University paper, and the college magazine; in his last two years he was a member of a play-writing clase. During this period of his interest in drama at Chapel Hill, he wrote three plays: The Return of Buak Gevin: The Pragedy of a Mountain Outlaw (in the production of this play Tom played the title rolo); Deferred Payment, and The Third N1ght--2 ghost play of the 
Caroline Mountains. His opinion is thet none of those were worth angthing as literature. After graduation, Thomes Wolfe also went to Harvard.

At the University of North Carolina Thomas Wolfe was implicated in a hazing that resulted in the death of one of his fellow-students. He, along with the other participents, was auspended from the University for a time, but was later reinstated. This event is omitted in Look Homeward Angel, probably because the horror was yet too much imprinted on his memory. But he mentions this erent in You Can't Go Home Again in a fictional letter written to h1s publisher. The purport of the letter is an explanation as to why he must change pablishers; one phase of it is the expressed desire to dispel any feeling that he was a bitter young man becanse of this catastrophe.

He says:

It was recalled how five of us (and God have mercy on the souls of those otherg who kept silent at the timel had taken our classmate Bell out to the playing field one night, blind-folded him, and compellod him to dance upon a barrel. It $\mathbf{7 a s}$ recalled how he stumbled and toppled from the barrel, fell on a broken bottle-neck, severed his jugular, and bled to death within five minutes. It was recalled, then, how the five of us--myself and Randy Shepperton, John Brackett, Stowell Anderson, and Dick Carr-were expelied, brought up for trial, relessed in the custody of our parents or nearest relatives, and deprived of the rights of citizenship by legislative act. 
AlI this was true. But the construction which pooplo put upon it when the book appeared was fal Bo. Mone of us, I think, was "ruined" and "ombittered"-and our later record proves that we wore not.6

His autobiography, The Story of a Novel recounts his reactions to writing. In decrying the ilterainess of his first novel, Wolfe says:

For although book was not true to fact, 1t was true to the general experience of the town I came from, and I hope, of course, to the general experience of all man living.t

This autoblography pictures the anguish, torture, defection, and obsessiveness he experienced in writing Of Time and the River, and pays tribute to the trust, patience and encouragement given by his editor, maxwell Perkins.

H1s desth on September 10, 1938, brought his writing to an abrupt end.

Following the pablication of Look Homeward Angel, 1929, three other novels, short story and an autoblographical sketch followed.

Summary: (1) Wolfe' fiction is more directly autobiographical than that of any of the other writers except Fisher; (2) it is an unusually full analysis of

6. Thomes Wolfe, You Can't Go HOme Again ToW York and Iondon: Harper and Brothers, 1934), D. 712.

7. Thoms Wolfe, The Story of a Norel (New York: Scribner and Sone, 1936), p. 22. 
the author-hero's mind; (3) it shows violent reaction against his confining background; (4) it tends to romanticize his father's family; (5) a very important incident, the hazing episode, is not mentioned.

\section{TREATMENT OF MAJOR PROBLEMS OF ADOLESCENCE}

\section{Treatment of Family}

In Look Homeward Angel the treatment of family turna on (1) emphasio upon lineage; (2) the strong cheracteristics and primitive impulses of the individual charactera.

The Gant family was very strongly divided by the two parental sides of the house, those showing Gant tendencies and identities on the one side, and those ghowing Pentland characteristios on the other. The Gants are W. 0. Gant, the father; Helen, Luke and Ben, Eugene's sister and brothers. The Pentlends are Eliza, the mother; Daisy and stephen, Eugene's sister and brother, and Eugene. Helen Gant, in a rage, reminded Eugene of his likeness to the Pentlands, Eliza's gide of the house:

"You Iittle Ireak. You nasty little Ireak. You don't even know who you are--you little bastard. You're not a Gant. Any one can see that. You haven't a drop of papa's blood in you. Queer one! Queer one! You're Greely Pentland all over again."

She elways returned to this--she was fanatically partiaan, her hysterical superstition had already 
Iined the familg in embattled groups of those who were Gant and those who were Pentland. On the Pentland side she placod Stere, Daisy, and Eugene-- they were, he thought, the noold and selfish ones," and the implication of the older e1ster and younger brothor with the criminal member of the family gave her an added pleasure. Her union with Iuke was now inseperable. It had beon ineritable. They were the Gants--those who were generous, fine, and honorable.8

The outstanding characteristice of the Gant alde of the house were boisterousness, unbounded vitality, ambition, licentiousness, and primitive appetites. Gant was a men of strong appetites, bolsterougly good-humored at times, enjoyed abundance in everything, disliked avarice, liked the theater, had some knowledge of literature, and enjoyed the respect of his fellow-townemen in spite of his drunken debeuches. He held no bitternese against Eliza for leaving him, although he occasionally referred to her as hoving deserted his "bod and board." He frequently visited among the bosrders at Dixieland, discussing politics and topics of the day.

Helen possessed feverish energy, hold an inexhaustible store of self-pity, imagining herself 1mposed upon by her family bat becoming enraged if not inoluded in ororything that concernod it. She was tho solfappointed nurse and housekeoper for her sick father, and when Eliza moved to Dixieland, she automatioally 
remained behind with Gant. She was the keeper of his health and welfare, and she considered herself a victim of any misfortune that assailed him. She was tolerant of her mother's caprices, harbored unconsciously a rivalry for Gant's esteem, and held a hamorous contempt for Eliza's bosrding-house.

Iuke was a stutterer, a most pereistent salesman, and a possessor of the characteristic qualities of the Gants.

On the side of the Pentlende were Elize, Daisy, Stephon, and Eugene. Eliza had a menia for the acquisition of property, and her foresight and intuition for good bugs in realty eventualig made her large profits. Her avarice and continued reference to herself and her famfly 28 poor, irritated Ben, who was the embodiment of generosity. She was not overly scrupulous about the boarders she harbored at Dixieland, but on occasions showed generosity toward unfortunates. In the cese of the pregnant woman without funds, she boarded her and paid her doctor bill.

Daigy married early in the novel and went to Birmingham to live, thus dropping into the background. Stephen was a licentious, drinking, cursing, no'er-dowell, who eventually married an older woman, one of Eliza's boarders, and went to Indians to live. Ben was 
a silent, steady plodder, working in a norspaper office. He was the soul of generosity and considered the fifts ho made to those ho liked as favors to himeelf rather than to thom. He blushod at their expressed apprecistion; answers and comments to most opinions were Will, what do you know about that!" Eugene was very much like Ben, and there wes a comradeship between the two that Engene did not feel toward any of the other family. W. 0 . Gant's attitude toward Engene was kindly, and interested. He took him to shows, to visit Deisy, gave him money for ice-cream sodas, and encouraged his education, seeing in him his last hope to make the name prominent, as he hoped, politically. Helen wes at times affectionate and at times abusive toward him. It amued her and fed her egotism when he would desert Dixieland and come to the Gants, and she enjoyed to the utmost her arguments with Eliza when the latter eventualig called, demanding his return. Iuke considered his younger brother lazy, and exhorted him to eell more Saturday Erening Posts, for which he was an agent. He routed him erom the public library, when he found him resting or loltering there; he instructed him in his own salesmanship tactics; his measure for Engene was his seles ability.

Eliza had on inaifferent affection for Eugene a 
her youngest child. She took him with her to Dixieland, and occasionally reminded him of being her baby. She saw however, no reason why he should not work and earn his keep; consequently she encouraged him in the agles of the magazines, berated him when his earnings did not measure up to expectations, exhorted him at all times under all conditione to "drum up trade" for her boarding house, and "to throw his shoulders back and make poople think he was somebody."

He was more attached to Ben than to any other member of his family. They were more nearly alike in feelings and attitudes, and the brothers felt this closeness.

Both Ben and Eagene were by nature aristocrats. Eugene had just begun to feel his social status-or rather his lack of one; Ben had lelt it for years. The feeling at bottom might have resolved itself simply into a desire for the companionship of elegant and lovely women: neither was able nor would have dared, to contess this, and Eugene was susceptible to the social snub, or the pain of caste inferiority: any suggestion that the companIonship of elegant people was preferable to the fellowship of a world of Tarkingtons, and its blousy daughters, would have been hailed wi th heavy ridicule by the family, as another indication of false and undemocratic pride. He would have been ceiled "Mr. Vanderbilt" or "the Prince of Wales."

Ben had an affection for and understanding of his younger brother that the others lacked. Eugene oherished

$$
\text { 9. Ibid., p. 123. }
$$


for years the watch given a birthday present by the older brother. Neoting him on the street, Ben often cuffed him affectionately, then took him into a restanant for something to eat. He criticised the family's negligence of the youth, and later, when Eugene was ready for college, advised him to take his perent's money for expenses rather than work his way through.

Bugene's attitude toward his family was alternating toleration and bitterness. He resented Ellza's mannerlams.

He writhed as ho saw himself a toughened pachyderm in Elize's world--sprucing up contidently, throwing his shoulders back proudly, making people "think he was somebody" as he cordially acknowledged an introduction by producing a oard setting forth the joys of Iife in AItamont and at Dixielond, and seized every opening in social relations for the purpose of "druming up trede." He hated the jargon of the protession, which she had picked up somewhere long before, and which she used constantly with such satisfaction--smacking her lipe as she spoke of "transients," or of "druming up trade." In him, as in Gant, there was a silent horror of selling for money the bread of one's table, the shelter of one's walls to the guest, the tranger, the unknown friend from out the world; to the gick, the weary, the lonely, the broke, the knave, the harlot, and the fool.10

He lacked Luke's enthusiasm for selling and disapproved of his tactics. He liked to hoor the jingle of coins in his pooket, but the thought of walking along the streot 
carrying a pack on his back was unbearable.

Iater, when Eugene was approeching young man-

hood he expressed the long suppressed bitterness toward his family which had boen accumalating sinoe childhood.

"I'm sorry I jumped on you, Ben. You," he said to the excited sallor, "fumped on my beck like a coward. But I'm sorry for what'g happened. I'm sorry for whet I did the other night and now. I said so and you wouldn't leave me alone. You've tried to drive me exacy with your talk. And I didn't," he choked, "I didn't think Jou'd turn against me as you have. I know what the others are like--they hate mo!n

"Hete you!" oried luke exoitediy. "For G-G-God's oake! You talk like a fool. We're only trying to help you, for your own good. Why ghould wo hate you!"

"Yos, gou hate me," Eugene said, "and you're ashamed to admit it. I don't know why you should, but you do. You wouldn't over admit anything like that, but it's the truth. You're afraid of the right words. But 1t's different with you," ho soid, turnlng to Ben. WO've been Ilke brothers--and now, jou've gone over against me."II

There was no unity of love or common interest in the Gant family; it was divided into groups based on Iikenesses or differences. Toleration of each other was the only basis of unity. The one group, the Gents, werie atrong in their omotions, in their appetites, and in their ambitions. The other group, the Pentlands, were, on the whole, less expressive, and more suppressive of omotions and appotites. A notable characteristic of the 
brothers, 88 a whole, was the lack of harboring bitterness after fist fights, of which there were several. Most of thom ended in acknowledgement of error and apology for cansing the eruption.

2. Ireatment of Institutions

The Institutions in Iook Homeward Angel aro odpoational, religlous, and social; that ir, the schools, the church, and the theoter. Eugene's most effective school training was received with the Ieonards and at the state university. The Ieonarda gave him the Impetus for developing his inherent telents, and the means for enlarging his knowledge and indulging his interest in ilterature. When he was selected as a prospective pupil of Mr. Leonard's private school, the Gant family snorted, identifying him with $\mathrm{Kr}$. Vanderbilt and assuring him he would be ruined. The Ieonards took the interest in him that they would have taken in an own child, watchful of his hoalth, his habits, sometimes indulgent; they were the blazers, opening up the way for him to the great classics and to the inspiring body of Iiterature they themelves knew and 10ved. Frgene learned easily, sometimes entengling Ieonard himself with clever questions, and he read ravenously, 
guided by Margaret Ieonard herself. of Margaret Ieonard, the author saye:

The wine of the grape had never atained her mouth, but the wine of poetry was inextinguishably mixed with her blood, entombed in her flesh. 12

His aniversity experience hinges on his eccentricities and the peculiarities of his conduct. During his first year he had a rebellious attitude; when the English professor interviewed him about outside reading and required a report on Barrie, Eugene agreed outwardly but resolved inwardy that he would read anything he plessed. His latin profossor accused him of using pony; he had not done this, but he resolved now to do so.

During his second year he engaged in series of javenile prenks. He delighted in ringing door-bells, announcing himself as Thoms, Chatterton looking for Mr. Samel T. Coleridge, and then enjoying the constermation produced. Sometimes other equally ridiculous impersonations were assumed. He was called queer and criticised for not taking baths, and for not changing his underwear more often, but he sneered at these attitudes; he thought of himself as a genius. He took walks at night, sometimes lotting out weird animal 
J०118.

He progressed from erasion in his flrst year to sociability in his last. He joined overything, and being of a noutral group ho was welcomed. At the commencement exercises which Fliza and W.0. attended, he gave the valodictorian oration. He was sad at learing the unirersity.

During one of his years he took part in hazing in which a fellow-student was killed; this incident worriod him, although ho did not mention it in Look Homeward Angel nor in of Time and the Rivex. It was not until the last rolume, You Can't Go Home Again was published that he summoned courage to put it in print.

His attitude toward church during his early years is described in the novel, but dolescent and meture attitudes are not expressed. As a child ho 11ked the romantic espects of the Presbyterian Church that he had attended for several jears and was awed by the solidarity and solemity of it. In the sunday school he liked the singing of the mixed roices of such songs as "Throw out the Iifeline," "Shall We Gather at the River," and "Onward Christion Soldiers." The author subtly roices his own attitude 
toward the various churches in the following:

Harry Tarkinton and Hax Isaacs were Baptists, as were most of the poople, the scotch excepted, in Gant's neighborhood. In the social scele the Baptists were the most populous and were considered the most common; their minister was a large plump man with a red face and a white vest, who reachod great oratorical effects, roaring at them like a lion, cooing at them like a dove, introducing his wife into the sermon frequently for purposes of intimacy and leughter, in a programme which the Episcopalians, who held the highest social eminence, and the presbyterians, less fashionable, but solidly decent, felt was hardly chaste. The Nethodists occapipd the middle ground between vulgarity and decornm.13

Eugene's particlpation in this Sundeg devotion was shadowed by his isolation from it. He was deeply attracted and mored by its gloom, the music, the prayers, and the pictures of Christian mythology which he collected as a child. From these forms he felt there was something deeper and greater than exterior decency.

The theater impressed Eugene immensely. His first visit to a theater was in Augusta while on visit with his father to his sister, Daisy. The play was founded on the story of Saul and Jonathan. He whispered to Gant from scene to scene the trend of coming events; this sophistication and enthusiasm pleased hil father greatiy. 
The sohool experiences of Engene Gant are marked by attainment rather than by enjoyment or sociability. His college experiences, in addition to at tainment, emphesized eccentricities that probably caused him to be considered as queer and peculiar. These singularities were certainly the basis of problems, as they were probably responstble for his Iack of associates and for the loneliness that is an ever recurrent allusion throughout his novels.

The church experiences emphasize his sensitivity to criticism, and a romantic tendency to admire and appland the boautiful in the service and in the church organism.

\section{Preatment of Associates}

The associates of Engene Gant in Look Homeward Angel hinge on his isolation in college and on his lack of associates as a child. In college, before his first yoar had ended, he had changed his lodging four or fire times. His last room was large, bare, and carpetless. Here began an isolation thet was hard to bear at first, but which became necessary to him later both physically and mentally.

His Closest associate was Jim Trivett, son of a rich tobacco farmer in the eastern part of the state. 
Jim"s nickname for Eugene was "Ieg8," and it was he Who was Eragene's companion when he had his first sex experience. This attachment, however, was neither strong nor lasting.

In h1s second year he was congenial with his roommates and popular in general, jet again he had no close associates.

He was happlex than ho had ever boen in his Iife, and more careless. His physical loneliness was more complete and more delightful. His escape from the bleak horror of disease and hyeteria and death impending, that hung above his crouched family, left him with a sense of aerial buoyency, drunken freedom. He had come to the place alone without companions. He had no connections. He had, even now, not one olose friend. And this isolation was in his favor. Everyone knew him by alght; everyono called him by name, and spoke to him kindly. He was not disliked. He was full of expansive joy, he greeted everyone with enthusiastic gusto.14

In his final jear, though still popular, his

aloofness was still predominant; he was considered queer.

Further, it annoyed and rounded him to be con- . sidered "queer." He exulted in his popularity among the stadents, his heart pounded with pride under all the pins and emblems, but he resented being considered en eccentric, and he envied those of his fellows who were elected to office for their solid golden mediocrity. He wanted to obey the laws and be respected; he believed himeelf to be sincerely conventional person--but, somone would see him after midnight, bounding along a campus path, with goat-cries beneath the moon. His auits were baggy, his shirts and drawers got dirty, his 
shoes wore through--he stuffed them with cardboard strips--his hate grew shapeless and rore through at the creases. But he did not mean to go unkemt--the thought of goffg for repaire filled him with weary horror. 15

This isolation is morely a repetition of his experiences as a child. He had only a fow associates ag a child. Max Iraacs and the Tarkintons are about the only ones mentioned as his childhood playmater. Ixcopt for a few boyish pranks such as chasing Jews and negroes, or exchanging wild west books, very little is ald of his early play lifo. The meagerness of his play life is striking; he is portraged as a brooding child rather than a a frolicking boy participating in games and sports.

Thas, pent in his dark soul, Eugene sat brooding on a fire-1it book, a stranger in a noisy inn. The gates of his life were closing him in from their knowledge, a vast cerial world of phantasy was erecting its fuming and insubstantial fabric. He steoped his soul in streaming imagery, rifling the book-ghelves for pictures and finding there such tressures as "With stanley in Africa,". rich in the mystery of the jungle, alive with combat, black battie, the hurled spear, vast anake-rooted forests, thatchod villages, gold and I vory; or Stoddard' "Ioctures" on whose glick heary pages were stamped the most-visited scenes of Europe and $A 812$; . .16

When he mored to Dixieland, he lost connection with his former friends and had only a few sporedic

$$
\begin{aligned}
& \text { 15. Ibia., p. } 589 . \\
& \text { 16. Ib1a., p. } 83 .
\end{aligned}
$$


associates who bored and wearled him. only children of boarders of Dixieland, or TIm O'Doyle, whose mother ran the Brungwick, or children here and there who held his interest for a short time were his playmetes. Dull children rexed him, and ho was more ennoyed with tedium in the I1ves of others than in his own. It angered him to observe them satisfied with monotony and tedinm.

He played games badly but was nevertheless interested in them. He admired Hex, even after their friendship had coolod, for his oxcollence in baseball, for catching gracefully what seemed to be impossible balls, and for his preciaion as hitter. Bagene tried to imitate his chum but falled boceuse of his olumsiness.

At the Ieonards, although ho is congenial with the other pupils, casual associations rather than intimate friendships onsue.

The boye he met at Sundey School were mere contacts; their lives did not touch his during the week; they living on Nontgomery street--the more fashionable part of town. At times they jibed him, saying, "Do you want to buy a saturay Evening Post, mister?n

Aseociates in Iook Homeward Angel are noticeable 
by their lack rather than by thoir presence. Ionolinoss, brooding, and isolation characterize his social 1ife, although these attributes do not prevent him from being popular and woll-liked. They are self-invited rather than enforced.

\section{Treatment of Sex}

Wolfe's treatment of sex tarns on (1) mental conflicts; (2) solution of the sex problem. The sex experiences in Look Homoward Angel were more of sensual intoxication than of fleshly pleasure. As Bugene ordered the negress in Niggertown to strip and dance before him, he looked on fascinated.

Her skirt fell in ring about her feot. She took off her starched waist. In a moment, save for her hose, sho stood naked before him.

Her breath came quickly, her full tongue licked across her mouth.

"Dance!" he cried. "Dance!"17

He looked on until the negress approached too close, then selzed with fear he managed his escape.

H1s next major sex experience was as nearly mental 88 the first and came to as inefiectual an end. It occurred while he and the little waitress, Louise, along with others, were on trip to charleston. The 
two had remeined behind in the hotel desiring to sleep, while the others had gone to visit the Navy Yards. Ioulse had gone to Eugene's room to wake him. A conversation onsued in which Loulse asked Fugene what kind of build he liked in girl and won a confession from him that he adired her build. Breaking down the reserve gradually and becoming more familiar, an impassioned love scone ensued, but ended as Ilatly as did the experience with the negress. The jouth's emotion dissolved itself in tears.

"Why, you're all excited, dear. There. Why, you're shaking like a leaf. You're high strung, honey. That's what it is. You're a bunde of nerves."

He wept soundressly into her arm. 18

A third experience ended in like manner. With Jim Mrivett, who had taken him to see prostitute, Iily Jones, he was seized with 1 liness and forced to retch in the gutter.

A determination to conquer this fear, or revulsion, ended more successfully in a fourth at tempt when ho visited Ifly Jones' house alone and asked for the other prostitute, Thelma. Dire results flollowed; he contracted a venereal disease which frightened him until he went 
home Christmas; through Ben's aid he sought a doctor's help and recovered.

He had one serious love affair with Iaur James, a boarder at Dixieland, which approached sex experience, but never progressed beyond the love stage. climbing into her room through window at night, they made love ecstatically. He relieved Laura's foars by tucking her in bed.

He stooped, thrusting his arm under her knees, and Iifted her up exultantly. She looked at him frightened, holding him more tightly.

"What are you doing?" she whispered. "Don't hurt me."

"I won't hurt you, dear," he said. "I'm going to put you to bed. Yes. I'm going to put you to bed. Do you hear?" He felt he must cry out in his throat for joy.

He carried her over and laid her on the bed. Then he knelt beside her, putting his arm beneath her and gathering her to him.

"Good-night, dear. K1ss mo good-night. Do you love me?"

"Yes." She kissed him. "Good-night, darling: Don't go back by the window, you may Ia11."19

Their lore still remeined unsuliled by sex fultillment, as they lay on the ground enveloped by impassioned emotion--they were on picnic alone. A drametic and

19. Ibid., p. 443 . 
tragic ond befell their romance when Iaura left at the end of June and wrote him a little later, announcing her marriage to another man.

\section{SUMAARY}

In conclusion: (1) Look Homeward Angel is a violent reaction against the small town; (2) a conspicuous tendency to romanticizo the hero, his father, and his father's family is shown: (3) the institutional influences it presente are these: (a) the religious outlook is neglegible; (b) educational equipment is necessary for achievement; (c) family and social maladfustment develop psychological conflicts; (3) the romantic attitude toward the family combined with the isolation of the gouth indicate the exaggerated perspective the author has attainod. 
CHAPTER IV

VARDIS FISHRR'S IN TRAGIC IIPE 


\section{CHAPTER IV}

\section{VARDIS FISHER'S IN TRAGIC IIFE \\ Adolescence in the Western Frontier}

The problem of this chapter is to discuss the attitudes toward adolescence as portrayod by vardis Fisher in his In Tragic Iife, 1932, the first rolumo of a tetralogy consisting of In Tragic Iife, 1932; Passions Spin the Plot, 1934; We are Betrayed, 1935; and Ho V1liain Heed Be, 1936. The latter throe novels were omitted from this discussion because they go on from adolescence to young manhood and then to adulthood.

Tardis Fisher was chosen to represent the late 1920's along with Thomse Wolfe because his treatment of adolescence presents a differont pattern from that of the other authors discussed; that of a western adolescent in conflict with frontier life, who emerges successfully, becomes college professor and author and comes to look back on his adolescent period as a most terrifying experience which influences his whole I1fo.

I. THE AUTHOR

The terials araflable about the author are 
an autoblographical sketoh in Anthors Todar and Yesterday, 1 an article by John Peale Bishop, "The Strange Case of Vardis Figher, 2 and his fiction. The fiotion is docidedy autoblographical.

His autoblographical sketch mentions his preferenoe for certain authors and discusses his private life $8 \mathrm{~s}$ a writer and his attitudes. He states that he takes pleagure in the impetuous headiong rhetoric of Thomas Wolfe, the superb craftsmanship of Willam Faulkner, the whimsioal tenderness of Robert Nathan, and the oblique and ponetrating realism of James Branch Cabell. He writea three or four hours in the morning doing about eight hundred words in the rough, revises them once, twice, or three times, but is still dissatisfied with his effort.

The predominant influences that have shaped his Iife according to his own analysis are the Bible, Purltans, moralists, college teachers of all sorts, and persistent observation of his fellowmen. He stated that he tries to portray life as he sees it,

\footnotetext{
1. Stanley J. KunItz, Authors Today and Yesterdar (Now York: The H. W. Wilson Company, 1933), pp.839241. This contains a statement about himself.

2. John Peale Bishop, "The Strange Case of Vardis Fisher," The Southorn Revier (Joulaiana: The Iouisiana sta to Un17ergity Pres8, 1937-1938), pp. 348-359.
} 
and has seen it, that his books have boen callod brutel and ruthless because he has seen so wuch brutality and believes that all aspects of life belong in a serious novel. He has no vision of a Utopia, hopes he preachos no morality, belleves that the only good book is an honest one, that romance is an adolescent attempt at escape from Iifo, and sees no reason for assuming virtues which we do not possess, or 100k with shame on those impulses which repudiate those imaginary virtues. The titles of his tetralogy are taken from George Meredith' femous lines in "Modern Iove" (Stanza XIII):

In tragic Iife, God wot, No Villain need be! Passions spin the plot; We are betrayed by what is false within.

Fisher states that his tetralogy, not yet completed at this time would "proceod from bowilderment and chaos into negativism, and then to a very positive attitude toward life." 4

John Peale Blshop's article "The strange Case of Vardis Fisher" establishes Fisher's tetralogy as autobiographicel and discusses it from the viewpoint of the frontier. The heroic age of the frontiersman is past,

3. Konitz, op. oit., p. 241.

4. Ibia., p. 241 . 
he saye, but because Fisher observed it honestly, his work has value. He declares that the name "Vridar Hunter" is most transparent disguise for Vardis Pisher and that there are oven more definite indications that the works are strongly autoblographloal in obaracter. His criticism is thet the form of fiction is carefully proserved through the first two rolumes bat broaks down in the last two, bocoming only a documontation of Fisher's opinlons on varioty of topios in the last. He otater:

- the story of Vridar is essentially one of fear and the struggle against a foar of life, whose causes, he would have us bellere, lie back of his birth. It is increased in his porertybitten boyhood by a ploneer up-bringing, at once brutal and idesilstic, undisciplined and roprossed.5

Mr. Fishor show an earnestness in portraying Iffe as he finds 1t, including men, women, and children; his men are the fearless, sensual, willful, love-gtarved type; the women are the lowa, coarse, fearless, superotitiou and puritanical type; hie children are the brutel, sensual, emotional and both fearless and cowardy type. He doea not wince at the brutality and cruelty that Impregnate that 11fe; he portrays the wildness and beanty of nature as a thing that bocoms imbedded in p. 350 .

$$
\text { b. Blahop, "The strange cage of Vardig Figher," }
$$


the people.

Plsher had written two novels and some poems previous to his norel In Tragic Iife; subsequent to this pablication he wrote eeven novels, one short story, an essay, and collaborated with others in a Guide Book and an Idaho Incyclopedia, prepared by the Foderal writers' projects of the Forks Progress Administration.

Summary: (1) the tetralogy is a vivid account of an impressionable jouth who became victim of frontier 11fe; (2) It is a signiflcant account of frontier 11 fo.

II. COMPARISON OF THE FICTIONAT CHARACTHR WIIH THS AUTHOR

Vridar Hunter, the fictional character is born, reared, and attends school in Ideho, attends rasatch University in Utah, serves in the army, graduates, gets his A. B. degree, then h1s Ph.d., teaches in the University of New York, then resigns to become a writer. He marries Neloa Doole while still in college, they have two children, and she commits anicide when she is sure Vrider intends leaving her to go with thene Marvel, an instructress at Fasatoh College.

Vardis Fisher, the author, 18 born, reared, and receites his early educetion in Iaho, attends the 
University of Utah, serves in the army, marries, and his wife dies. He remarries, tesches in the Univereity of Utah, then in the University of Now York; he resigns from this position to return to Idaho to write.

Vridar Hunter, the fictional character, was the son of Joseph and Prudence Hunter, pioneers in the Antelopo hills in Idaho. The wild country at once faccinated and hold him with foar. He foared the river that rushod by their farm, the storms that roared through the trees, and the loneliness of the night. He wrote verse early; it was the one comon purpose of his parents thet their children should be educeted, and toward that ond both parents worked hard and for long hours.

Vardis Fisher, the author, was born in Annis, Idaho, March 31, 1895, the son of Joseph and Temperance Thorton Fisher, ploneers, and also the descendants of pioneers. Kunitz 6 states that he wrote a complete novel while in high school, which he barmed, and enough bad verse for a complete edition. Pacts about his early IIfo and schooling are not avaliable; howerer, except from his fiction.

The hero's and his brother Mertyl's early

6. Kanttz, op. CIt., p. 240. 
sohooling was obtained under adrerse conditions. Due to its remoteness they had to live away from home, spenaing an unpleasant year at Annis with thoir Aunt Agne 8; the following years were spent "batching "in an old shack and in a crudely constructed hut until the high achool course was completed. The following year Vridar entered the University of Utah. After his first year he married Neloe Doole, a childhood schoolmate. She returned with him to Salt Iake city; during his second year he joined the army and was sent to Callfornia. Dissatisfied and foeling the inferiority of his clothes to that of his associstes he asked to be discharged. This was granted, and he returned home, saw h1s new-born son, and was absequently drafted. After the war was over he returned home, became successively garage manager, bootlegger, and taxidriver. He decided to return to college and graduated, and was offered a place on the faculty in the Fnglish department provided he would attend the University of Chicago during the summer.

This sumer marked the beginning of Vridar's and Neloa's quarrels that eventualiy led to her suidido. on the faculty at the college was Athene Marvel who became friendly with Vridar and promisod to leave with him. 
This information was given to Nelos by Vridar, who wished above all things to be honest with her; she apparently accepted the outcome but drank poison and died when he Iinally bolted.

Fioher, the author, cerred in the Unt tod States army in the World War; he was married in 1918 to Ieona Molartry; they had two children, Grant and Wagno. H1s wife died and ho married Margaret Trusler in 1929. He received his A. B. degree from the University of Utah in 1920, h1s M. A. from the University of Chlcago in 1922, and his $\mathrm{Ph}$. d. from the University of Chicago in 1925. After three years as instructor in English at the University of Utah he went as English instructor to the University of New York in 1928.

Vrider resigned his progressorship at the University of Utah and went with Athene to ashington, where he worked in the Iibrary of Congress on his thesis for a $\mathrm{Ph}$. d. degree. Returning to Chioago he submitted his thegis and received his degree. He went back to the University of Utah as English professor and resigned after three years to go to New York, teaching at the University in the same capacity. After several years he resigned here to return to Idaho to write and to choor his aging parents. 
Summary: (1) The novel is heavily autobiographical; (2) both author and character are born and reared in Idaho; both (3) attend the University of Utah; (4) marry, have two children, and their wives die; (5) serve in the army; (6) obtain A. B. degrees, then Ph. d.'s; (7) remarry, teach in the University of Utah and New York, and resign to return to Idaho to write.

III. TREATMENT OF THE MAJOR PROBLEMS OF ADOLESCENCE 1. Preatment of Family The family relations of the novel are three101d: (1) the ancestry; (2) the immediate family; (3) the patornal relatives. The first explains the beginning of the Hunter clan in Idaho, the second presents the family at the time of the writing of the novel, and the peternal relatives give a picture of the frontiersmen.

The Hunter clan descended from the union of Joe Hunter and Rose O'Rourke, an Irish maid of selt Lake Valley, whose parents had gone westward with Brigham Young. The couple settled in Idaho about 1870. The fearlessness which characterized the family wos demonstrated by this ancestor; armed with only anife 
he slow a monstrous boar which was mutileting a man. The oharacteristica of Joe Hunter, the son of the pioneer and the father of the boy, Vridar, were sterness, silence, sensitiveness, and at times cruelty, forrlessness and ruggedness; in contrast to these he had a secret passion for poetry and literature, and, the author tells us, might have been a poet if work had not taken him to the fields. Vridar caught a glimpse of this strange side of him while ho watched h1s father's reaction to a novel whioh Prudenoe read. He felt then what he learned in later years that the father's silence and Bcorn were only masks for a hunger for love and tenderness. His one gosl, the strbborn purpose which was mutual between him and his wife, was to educate his children.

Vridar's attitude toward his father, during the se early years, was a strange alloy of reverence and fear. The man for him was a powerful giant, lost in sllence and work. His scowl was black and terrible; in fits of rage he swopt everything from his path. His stubborn will was as invinoibio as a ledge of stone. Never Within Vridar's mowledge ither now or in later yoars, did Joe admit himself to be defeated or brutal. He met acousation with rage. When foeling too doeply his stupidity or guilt, he would try to curse it out of him, or he would be driven by hame to the abuse of some defenseless ereature."

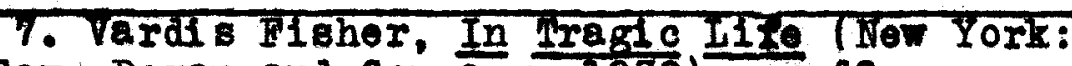
Doubledey, Doran and Company, 1932), p. 68 . 
This picture of Joe Hunter is in direct

contrast to the one Ihomas Wolte gives of W. 0 . Gant

in Look Homeward Angel:

Gant was a great man, and not a singular one, because singularity does not hold lite in unyielding devotion to it.

As he stormed through the house, unleashing his gathered bolts, the children followed him joyously, shrieking exultantly as he told Eliza he had aeen her "wriggling around the corner like a snake on her belly, " or, as coming in from Ireezing weather he had charged her and all the Pentlands with malevolent domination of the elements.

"We will freeze," he yelled, "we will freeze in this hellish, damable, cruel, and God-for saken climate. Does Brother Will care? Does Brother Jim care? Did the old Hog, Jour miserable old father care?

"But they can eat!" he shouted, plunging suddenly at the kdtchen door. "They oan eat-when oomeone else will feod them. I shall never forget the old Hog as long as I live. Cr--unch, cr--unch, cr--unch," --they were 211 exploded with laughter as his face assumed an expression of insane gluttony, and $\mathbf{8 s}$ he continued, in a slow, whining volce intended to represent the speech of the late major: "'Pliza, if you don't mind, I'll have some more of that chicken' when the old gcoundrel had shovelled it down his throat so fast wo had to carry him away from the table."

As his denunciation reached some high extravagance the boys would squeal with laughter, and Gant, inwardiy tickled, would glance around slyly with a faint grin bonding the corners of his thin mouth. Eliza herself would laugh shortly, and then exclaim roughly: "Get out of here! I've had enough of jour goings on for one night. "8

8. W0110, Look Homeward AngeI, pp. 64-65. 
The mother of Vridar Hunter, Prudence Hunter, was of a kindlier disposition than her husband, but sternness, capacity for work, and fearlessness were her chief traits also. Unlike the father, she felt instinctively the fears that beset her son, and to him She was a symbol of security. She was utterly right, the son thought, and to will a thing was to perfect its accomplishmont. Complaint was foreign to her, even though her life was lonely in the dosolate wildernesa where they lired, and though her work was the hard toil of the frontier woman.

The Hunter family, especially Vridar's Aunt Agnes Hunter, his father's sister, were coarse, lowd, profane, prejudiced, and delighted in malicious jokes. It was these tendencies that prompted Agnes to cook only the plainest food for Vridar and Mertyl when they stajed with her, then secretly to rise at midnight and produce rich and spicy foods for her and Borg, her husbend; it was also the basis for her mirth when Vridar suffered from rash contracted by puling up polson ivy around her door at her request; Vridar was bitter because she knew what the weed would do, while he was Ignorant of it. The following quotation gives a characteristic picture of Agnes: 
Agnes rose with roluptuons laziness and jawned. When she approached the halry man he yanked her sprawling to his lap. He pushed her back, broke her over his knees; and Vridar stared at the two mounds of her breast. With a finger then the man probed at the abdomen, and he made a fierce amorons sound full of $z^{\prime} \cdot s$ and b's. She lay prone, abandoned, her arms and hair falling to the floor. plesse!"

"Agnes!" Prudence cried. "I want your help,

She tumbled upward, yawning, crying "oh-oh!"

"You big lazy Swede," said the hairy man, "go make yourself useful. A hell of a wifo you'll

The father, Joe Hunter, inspired Vridar with admiration for his courage, apprehonsion of his wrath, cruelty, and bluntness, and a reverence toward him when his kindlier moods moved him to render tender care to injured or sick animals. His generel attitude toward his father was shyness and silence in his presence, evasion, and forced respect. Toward his mother he felt complete faith in her wisdom, admiration for her capacity for work, and misery and insecurity in her absence. Toward the paternal relatives he felt repugnance, distrust, and dislike, especially for his aunt. Toward Mertyl, his brother, he had assumed the role of guardian. He had early appointed himself as

9. Figher, In Tragic Iife, p. T8. 
his brother's keeper, and their association was the nearest to a congenial companionship that Vridar enjoyed.

Sumary: (1) The fearlessness demonstrated by the first Joe Hunter was characteristic of the whole clan of frontiersmen; (2) the fearlessness of the father, Joe Hunter, inspired in the jouth admiration and fear of the father but contempt of his own fear; (3) his relatires did not arouse his admiration; (4) he was closest to his mother.

2. Preatment of Institutions

The institutions and spiritual influences treated in In Iragic Iife are religlous and educational. The religious influences are the Bible and the church; the educational institutions are the grade schools and high school.

Religioue experiences hinge on sex curlosity, reading the Bible, and expiation for sex-sinning. Passages in the Bible referring to sex eroused sex curiosity; his affiliation with the church caused him to decide to go to the missionary field to atone for his practice of mesturbation. Vridar had early acquired an extensive knowledge of the Bible, and had meditated on its teachings; he often pondered orer 
verses, words, and sexual references. Before he had atarted formally to sohool he had read first the children's, then the adult odition. He confided in his mother that when he grew up he wanted to be a prophet. He imagined himself a prophet and then Jesus himself, and had faith that he could move mountains. He put this ability to a test; the results were doubtful after watching sereral days to see if the mountain moved, but he decided it must have mored because it mould be sinful to distrust the ebility of divine power to manifest itself in him.

He had visions at this time; later he explained these as cataleptic trances. In one vision he sav a great lamb with seren ejes and seren teils against a background of red and white; on an altar sat a great White God surrounded by angels; four horses entered; one red, one black, one green, one blue. They raced around the throne, stars fell, the moon turned black, and the sun became a basketful of blood; the bessts knelt before the throne, and it began to hail arops of blood; trees withered and when the beasts arose they had the heads of wolves.

Iar above ho saw a white splendor welking; when it spoke, plagues fell and devils ran frantic 
through fogland. He heard the volce of sevon thunders. Bodies lay dead upon the earth, and people danced around them; then the bodies rose and went to God. He saw himself borne upward with Mertyl olinging to his feet; then Mertyl loosened his hold and fell to a gravejard of dead things. He went on to the temple's door, angels swarmed around him, and ho was given book which tasted like honey. Then he walked to the throne and knelt, and a crown of gold was placed on his hood.

When he was in Rigby he went to church and was baptized, because most people went to church. His opinion of church-goers, nevertheless, was similar to that of his father--that is, that theg went to church on sunday and sinned the rest of the weok. When he was in high school, he decided to go to spain as a missionary in expiation of his sex-sinning; this resolve, however, dia not materialize.

His passion for truth is illustrated in his Christmas experiences. The first Christmas in h1s wilderness home wes a wondrous occasion; he had recolved a new oap, harmonica, some peenute, licorice, and big red apple. The second Christmas, he found in his mother's tocking--hung up becsuse he had none 
of his own--the old cap and harmonica with some peanuts and candy. Humiliation and disappointment crushod him; he would rather have had only the peanuta than to be led to believe in santa claus and then deceived in this manner.

His school experiences offered more hardshipe and diseppointment then it did pleasure and enjoyment. In addition to the unploseantiness of living away from home, he had to establish his security in erery school he attended by Ifghting--a necessity that sickened him with fear and frenzy.

His attempt at verse-writing in high sohool onded in frustration. The principal had comented favorably on som of his verse; thus enoouraged, for three weeks he hang anonymous verses on the blackboerd; finally the principal advised him to discontinue this practice, because the school was laughing at him; Vridar was wretched at this rebake. Sereral pleasant experiences intervened to make his school days bearable. Once he was viotorious in a spelling-match, in which he out-8pelled Neloa Doole; again he conquered his shyness sufficiently to make frlends and a skating companion of a girl named Helen; a third enjoyable occasion wes Helen's birthday party. 
His inability to present a birthday present threatened embarrassment, but he was saved from this calamity by Helen's quick thinking. Asked by Alvin Kress where his prosent was, sho answered for him that he was having his made to order and would give it later.

Sumary: The reading of the Bible gave his Imaginative mind food. This accomplishment at an early age, his Visions, and his tendency to impersonate prophet and God, mark him es precocious and sensitive rather than rational and normal. H18 baptism and church attendance show desire to be like other people, and his will to go to foreign filelds as a missionary show an orer-dereloped sense of sin. His convulsive fights at school reveal a queerness in his mental complex, probably due to former lack of associates. They open way for future companionshtp and bolster his will to overcome his mental handicaps. His pleasant experiences make the more unpleasant ones endurable. The treatment of institutions emphasizes the meagerness of the youth's opportunity to form pleasant associations.

3. Treatment of AsBociates

The treatment of associates hinges on the hostility of the contacts afforded. Vridar Hunter's associates consist of two groups: (I) his nelghbors 
and his cousin; (2) his school associates.

"Oh, so thet's what you want a-see mo for!" Alvin I anghed. "Sure, I remember. I said he was a little or 08s-0jod son-of-a-bitch!"

This wa what Vridar had wishod for; words that would come like a blow. Suddonly, owiftly, the world lost all moning and ho went mad. He gave or $y$, an insane gurgling $y \cdot 11$; he leapt like a tiger but without knowing the the leapt. Ho knew nothing, indeod, until several moments later, whon he found himself struggilng like a wildoat and soreaming. $0111 \theta$ and Doag and Mike were talking in his ear, pleading with him, and the were trying to hold his violent arms.

A little way off eat Alvin, with blood running from his mouth with blood soaking his white shirt and his hands. 10

This soene is characteriatic one of both

groups. The reasons for his fights were (1) necoseity from having e fight forced upon him; (2) for aronging insults to himself, to his mather, or to Mortyl; (3) disenading attentions of other boys to girls he admired; and (4) bocause of his cousin's oruelty to aumb creatures.

With the children of his own neighborhood, the nocossity for lighting was on acute problem. Hio only neighbors in his widerness home were the Bridwells, and before he started to school he received a threshing from Jod Bridwell. Jed acoused him of 
tattling to Charley Bridwell about the kistreatment of his sister--throwing her down and exposing her body to the boys--and caneing him to get whipped. Jed's revenge bore painful and cowering effects upon Vridar.

Jed did not wait longer. He loapt forth and broke the cowering lad to earth. He knelt on him, pinned his arms in deep soil, and fod soll into his mouth. He stuffed his mouth full, pounded the esrth in with his fists; until ho saw Vridar's faco darken, his yos bulge. Then he sprang up, ran softig to the river's brink, sank under $1 t$, and disappoared. 11

With his cougin, Hanke, al though his association was comparatively peaceful, he fought because of Hanke's orvelty to dumb things. Hanke robbed bird's nosts, cat the legs off frogs and left the mutilated bodies to die, and split a magpie's tongu, declaring that it would thereby talk. This cruelty olckened Vridar's seneltiveness, and they fought, Vridar victorious.

At the first school he attended he avolded fighting for a time by ignoring insults to his mother and most times remaining indoors at recess. Caged and forood to fight, he struck like lightning, routing his foe and winning freedom. Emboldonod by his first fight he engaged in another to make boy desist from paying 
persistent attentions to Heloa Doole, whom Vridar secretly admired. In his second school at Annis, ho Felt he had to proffer fight to ollie Bitt to clear his honor after 0llie had leered at Mertyl's orossed eyes. But ollie took to his heels, reliering Vrider of the necessity of fighting. High school was an excoption to this routine; he was freod from the necessity of fighting to establish himself; ho mede no close Iriends, however. He admired girls secretly, his shyness not permitting spontaneous friendahip. Summary: The treatment of associates is characterized by (I) fights with neighbore and schoolmates; ( 2 ) shynosa in regard to girl associates with one exception.

\section{Treatment of sex}

The treatment of sex is signifioant because of (1) its range and intensity; (2) fear of women; (3) sexual jealousy. The author treats the sex problem as one of the most serious of adolescence. It occupies a prominent place in the first three novels of the tetralogy. The intengity of Vridar's emotions is proportionate to his early interest in sex and his emotional instability is the result of his early training. H1s interest in sex had been aroused by Bible passages; by 
animal birth, by the obscene piotures and inscriptions on school toilets, and by the sensual caresses of the older boys and girla. In his early adolesconoe he had practiced masturbation, schooled in it by his cousin, Hanke. This practice he considered sinful, and he refrained from it until his will-power could no longer resist. Discovering in an old book that such practice led to insanity he subsequently imagined himself becoming insane. Unable to sleop at night, or waking, drenched With perspiration, he frequently spent the remainder of the night wandering aimlessly.

The advice of two people was helpful in freeing him from this fear of dementia; Dr. Gann, to whom Vridar had gone in a state of agitation, had given him understanding:

"Most young men do what jou have done. Maybe you got the idea you were the only person in the world doing such a thing. That's a very silly 1dea. Nearly everybody does it at some time in his life. Didn't you know that?"

Vridar stared at him. He know that denial was useless now.

"You mean--? Oh, but that can't be true! wy God, I know that.ion't true!"

"It is true. But most of them don't get upset. They don't think they're going crazy and all that tomarot. Realize that. You've been listening to silly stories or reading quack books. Haven't you?n12

12. Ibia., p. 452. 
He advised him to work hard, until he was tired enough to go to sleep, and to keep his mind oft himself. The other person was one of his teachers named Turner who had met him one morning after one of his all right jaunts and guessed the reason. Tumer laughed at his intention of becoming a missionary so heartily it became contagious, and Vridar laughed also. His remedial advice was to commune with nature, smell flowers, lie in the grass and $100 \mathrm{k}$ at the $\mathrm{sky}$, and meditate on the beauties of nature. Vridar tried this suggestion and found it helpful.

The basis of Vridar's struggle with sex is the attitude of sex-suppression in his home--the puritanical views of his parents and the misrepresentations made to him in early childhood. From the mother's point of view sex was a thing of shame, not to be discussed. Her method of dealing with sex questions was to give evasive or fabulous answers. Her explanation of animal-birth was that the mother dug the infant out of the ground; failure to discover such holes shook Vridar's faith in his mother's veracity. Happening on a cow giving birth to a calt convinced him of the falseness of her explanations. Fear of her blushing or hesitancy in answering had often caused him to refrain from asking questions. 
H1s association with women was not of an

intimate nature. Opportunitios were rejected often at the crucial moment bocause of his early training. A half-dozen women came within his reach, but none were ever touched. The reason is given in the follow-. ing quotation:

But Vridar berely heard. He was absorbed by the fight going on within. He prayed that something would snep and set him free, so that he could take this girl, so that he could rise to manhood and claim his right. But he was only a fool, terrified by a woman's mouth. When a girl offered herself, he quaked and ran cold, as if his veins were filled not with blood, but with ombalming fluid...13

Some of Vridar's adolescent delinquencies are without doubt closely connected with sex-suppression. His petty thefts, sterling cigarettes and beer during h1s high-school days, his and Mcclintock's dishonest scheme for getting Iree groceries while in college, their plan for getting now clothes under false pretenses, and his participation in drunken debauches are the companions of emotional upheavals and the outlet of sex-impulse in lieu of sex-indulgence.

A nourotic attitude toward sex is shown by his Insane jerlousy of Neloa Doole, his fiancee.

13. Vardis Fisher, Passions Spin the plot (New York: Doubleday, Doran and Company, 1934, p. 333. 
"Neloa, it's not the truth! Darling, say 1t's not the truth!n

"It is the truth," she said.

"No:" He grasped her shoulders and for a moment he intended to choke her. "It isn't, I tell you! It 18n't!" He was Irantic now. He wanted to kill her and he looked round for a club but he could see nothing at all. Screaming at her, he said, "Tell me it isn't!"is

The above quotation is an outbarst of his enraged jeslousy when Neloa confessed to having had sex relations with other mon. His erantic attempt to clear her name of the taint these associations had given it, occupled six weeks of a summer's racation. Frequently their bitter and emotional quarrels reduced Nelos to tears, and in later years he docided that he had three reasons for exciting this emotional upheaval; (1) that their mutual tears stirred and softened his sexual hunger; (2) he believed that tears purged her of sexual sins; and (3) the artist in him demanded that all things be dramatized.

Vridar's struggle with sex problems form the basic struggle of his life. It hinges on the puritanical attitude of his mother, the lack of confidence betweon father and son, forbidding open discussion of sex; the early misrepresentations, forcing the boy to 
meke his own deductions, and upon on over-developed sense of the sin and consequences of masturbation.

\section{SUMMARY}

In conclusion: (1) In Tragic Iife is hesvily autoblographical; (2) it shows a youth in violent conflict with his environment; (a) the influence of the Bible is emphasized rather than that of the church; (b) the alm of education was to avoid the frustration of the parents; (c) sex-maladjustment developed mental conflicts; (d) the brutality and hardship of the frontier were emphasized; (3) the portrayal of the hardahip and brutality of the frontier indicate the bitterness of the author toward his adolescent period. 


\section{CHAPTER V}

JAMESS T. FARRPLI'S

YOUNG LONIGAN AND YLTHER IND SON 


\title{
CHAPqTR V
}

\author{
JAMES T. FARREHI'S \\ YOUIY LONIGAN AND FATHER AND SON \\ Adoleacence in an Iriah Catholic Nelghborhood \\ of Chioago
}

Young Lonigan and Pather and Son are the only two novels by the same author included in this study. Bach is that part of a trilogy that deals specifically with adolesconce; in the former adolesconoe is seen at the boginning of the trilogy, the latter at the end of a Iine of development. Both deal with the adolescence of Irioh Catholic boys in a mid-western metropolis. Studs Lonigan is middle-olass: Danny O'Nelll is lower middle-clas8. Studs affords a study of a type-character portraying some of the tendenoles of the period; Danny O'Ne1ll is more immodiately autoblographical--more the portrait of the author in adolescence.

\section{THE AUTHOR}

Farrell himgelf was born in 1904 and 18 of Irish Cathollo stock of Chicago. He went from St. Anselm Grammer School to St. Cyril High school and on to De Paul University and to the University of Chicago, once a Beptist, now a secular institution, where he developed 
into socialist and a creative writer. Though a Marxist in politics ho does not believe that literature is purely propaganda. The aim is not tracing the economic origins of social and cultural movements, but the assimilation and presentation of life. 1 .

The writing of the stude Lonigan trilogy was the result of studies at the University of Chicago. 2 In the spring of 1929 he took a course in adranced composition from Professor James Weber Iinn at the University of Chioago. He wroto thousands of words--impressions, anecdotes, book-reviews, and essays--most of them relating to death and disintegration. One of these stories was ent1tled studs, a story of a waike told in the first person, which was originally printed in "This Quarter." The corpse was a young man from the FiftyEighth streot noighborhood who died suddenly at the age of twenty-six. The group of mourners recell with nostalgia the past jears and relate details of their current Iffe. Professor Iinn read the story enthusiastioally to the class; Farrell asked Professor Lovett to read and criticise it. The latter suggested that ho

I. Charies I. GIlcksberg, "Contemporary Crit1018m," South Atlontic Querterly, October, 1936, pp. 465-457.

2. James T. Farrell, "A Novelist Begino," Atlant 10 Monthly, September, 1938, pp. 330-334. 
develop it at greater longth. The trilogy with Stude Ionigan as the horo was tho result.

I saw in the character of Stude Ionigan, who was growing in mind, a number of tendencies at work in section of American life which I happened to know because it had boon a part of my own education in living. I began to see studs not only 2. a character in imaginativo fiction but also as a social manifestation. In the early stages of writing this work, I analjzed my character as I considered him in relation to his own world, his own milien. I set as my aim the unfolding of the desting of Studs Ionigan in his own words, his own actions, his own patterns of thought and feoling. I doclded that task was not to state formally what life meant to me, but to try to recreate a sonse of what life meant to studs Ionigan. 3

Studs Ionigan represented to Farrell a type of Irish catholic youth that Farrell saw developing within his own experience. Studs was the son of Irish catholic imigrant parents of the bourgeois class who expected the church and the school to direct the spiritual and educational welfare of their children. With this direction, supplemented by good example at home, they expected the children to attain a higher plane than they had reachod. Studs is also typlcal of the youth of Farreli's experience who are the victims of the prohibition evils. Drinking had become a ritual, a gesture of defiance, and the disasters that befoll studs are

3. Farrell, "A Novelist Begins," op. c1t., p. 33L. 4. Ibid., p. 333. 
akin to those that befell other youth--blindness and impaired health.

The Danny O'Neill series which followed the Studs Ionigan trilogy, represent an effort to look more deeply into himeelf without ceasing to recall objectively and to observe.5 Danny $0^{5}$ Neill represents to Farrell a youth more akin to Farrell himself--one who respond in a degree to the teachings of charch and school, but who finds in the end that they aro insufficiont for his neods.

Charges were brought against him by the Society for the Suppression of $\mathrm{V} 1 \mathrm{ce},{ }^{6}$ which counted seventyfive indecent passages in A World I Never Made, the Iirst of the Denny O'NeIll series, and issued a warrant to have the remaining copies impounded at the publishers and the latter sued. The magistrate threw the case contemptuously out of court, after a roster of outstanding writers had issued an indignant eulogy in Farrell's defense. Ifbraries, nevertheless, were scared into taking his norels off their shelres, and a store selling his books, in Milwaukee, was raided by Socialist police backed by a socialist mayor. Again

\footnotetext{
5. Farle Bierney, "The Fiction of James T. Farre11," Canadian Forum, April, 1939, p. 22.

6. Ibld., p. 23.
} 
Farrell was defended against the Milwauke leadere by a rally of artists. H1s defense against "the bad smell of the world lay in the title, A World I Nerer Made. $" 7$

He received a Guggenheim fellowship award for the purpose of finishing 1 World I Never Made; ${ }^{8}$ and in 1936 the Book-of-the-Month Club gave him one of the $\$ 2500$ prizes presented to authors whose work was both distingaished and insufficlently recognized. The following week the Iow York Times, efter having refused space to advertise Farrell's books, ran a large advertisement for studs Ionigan.

Farrell'a literary worke consist of eight novels, numorous short storios, and a literary critiolom.

Summary: (1) Farrell has developed from an Irish cathol1c background into socialist; (2) he regards Iiterature, howerer, as a means of presenting experience rather than of advancing economic theories; (3) his Irankness has led to prosecution and vindication of hio fiction about adolescence.

II. COMPARISON OF THE FICTIONAI CHARACTER WITH THE AUTHOR

The Danny O'Neill series are autobiographical.

7. IbId., p. 26.

8. Ioc. cit. 
Danny O'Neill, our hero, is born and reared in chlcago, is Interested in sports, especially baseball, attends Catholic schools, and studies at the university. Ho has the experience of working at a service station and at an express office after he graduates from high school. Parrell, the author, was born in chicago, attended parochial school and graduated from a catholic hIgh school, attended De Paul Unirersity and tho University of Chicago, but did not obtain a degree from either. He also had the experience of working as service employee and as clerk in on express office. In the Denny O'Neill trilogy the oetting is in a Cathollo locality in Chloago. Danny 1s interestod in bssoball and football in his grammar school days, and this interest continues into high school. He is especially interested in baseball and later in football. Along with his interest in sports he is also a good atudent, making good grades and hoping to win a scholarship to a Catholic high school. He does not succeed in doing this, but attends high school nevertheless. one is Impressed with the extent and exactness of baseball lmowledge Danny has at an early age, and according to Bierney 9 these facts are produced entirely from Farrell's 
memory.

Two out already in this inning. God was helping sd Walsh. Riggert up. out. oh, you Ed, Walsh. God wouldn't lot him hit Walsh now. He atood on his seat, jelled himself hoarse, olepped his smell hands, and Waleh walked into the benoh, receiving a thunderoub ovation. And it increased a.s he walked out, bat in hand, to start the White Sox half of the inning. He laced out a single, and the bat boy ran around to firgt base carrying a blue sweater for him to weer on the bases so that his arm didn't get cold. Danny watched Ed Walsh, his foot on first base putting on his sweater. With eyes of adoration he followed Walsh's fingers while the big fellow buttoned his sweater. And he clapped his hands whon Plng Bodif with two out, smecked a single, and valsh scored. Io

Danny goes on to high school and becomes an outstanding football pleyer. His work goes down in proportion, he otten copies his assignment from more industrious students, and 18 frequently reprimanded by the brothers for not producing better quality of work.

Farrell, the author, also reared in Chicago, had no 11terary or intellectual interests in his boyhood. His Interesto were chiefly athletic, 11 and he worked hardest at baseball at St. Anselm Grammar sohool. He took letterg in football and basketball at st. Cyril High School.

10. Jame 1. FarreII, A Rorla I Never Waa (Now York: The Vanguard Press, I986), p. 38. 
The college oareer of Danny, the hero, is not disoussed in the fiction. Father and Son leave him after graduation from high school working as clerk In the express offioe, where his father, who had just died, had worked before him. At this point of his Iife there was not much hope of his going on to college, where he had dreamed of winning honors as an athlote. The father's death, leaving a large family whose support depended on the two older boys, B1Il and Danny, left no prospective college careor for Danny to hope for. In addition, Bill's interest in a girl, whom he introduced to Danny as a future sister-in-Iaw, thrust a college oareer atill farther into the background. Yet Danny did attend college, as Ferrell, the author did, because in the "Studs Lonigan" trilogy he 1 s referred to thus:

A disturbing sense of loneliness caused Danny O'Neill to close the copy of Theory and Businese Enterprise which he was studying for one of his courses at the Unirersity. The elation of intellectual discorery and stimalation, the keenness of feeling mental growth within himself, the satisfaction of having uncovered additional proofs to buttress his conviction that the world was all wrong, which he had derived from his reading, suddenly ossed. 12

Farrell, the author, went on to De Paul

12. Farrell, Young Manhood of Stude Ionigan

(Nen York: The Modern IIbrary, 1938), p. 369 . 
University and to the University of Chicago; at the latter he began witing and made up his mind to become a writer. He never obtained degree from elther university, ${ }^{13}$ and his college interest centered chiefly on writing. He enrolled in various classes only to drop out before the term was finished.

Similar experiences in work listed are that of clerk in the express office and service station employeo. The conclusions arawn from this comparison are (1) that the Denny O'Neill series are autoblographical; (2) that this trilogy is an honest effort to portray a more normel side of Irish Catholic adolescence in contrast to that of Studs Lonigan.

III. TREATMENT OF THE MAJOR PROBLEMS OF ADOLESCENCE 1. Treatment of Family

In the Studs Ionigan trilogy, Studs is portrayed as rebellious againgt his family. Emphasis is on the failure of family, both parents and brothers and sisters, to do anything for Studs. In the Danny o'Neill series, Danny is portrayed as a link botween two families at somewhat different spiritual and economic levels. The emphasis is on the normal development of Danny from childhood through adolescence. 
The Ionigan family was of the bourgeois artisan class; his father was the manager of a small paint business. Both parents were of Irish descent, without educational background, deeply religlous, and ambitious for their children. The family onjoyed financial security, a good social standing among their neighbors and other parishioners, and were inclined to be critical of the manneriams of people less fortunete than they. Theg oriticleod Mrs. Rellly a being "common," a "greenhorn," whose English wes "awfully bad." Patrick Lonigan spoke disparagingly of Dinny Gorman for "sticking up his nose and actin' like he was a highbrow, lace-curtain Irloh, born to the purple." He asserted he had known him when he "didn't have a sole on his shoo." Mrs. Ionigan remembered the patronising manner of May Gorman when she invited her to tea but requested her to call first because they had so many engrgements.

Studs' attitude toward his family was rebollious.

A red flush from the slap he got appeared on Stude' left cheok. Uncontrolled tears welled forth. He wanted to hit back. He was afraid of his father. He sniffed without will.

The old man dropped back to his rocker, held his head in his hands. Studs looked at him and imagined himself gmashing the old bastard's face till it bled and swelled. He stood impotently.

"Yon heard me! Tomorrow! Now get the hell out of my sight before I give you the trimming you. 
deserve, you dirty little whelp!n14

Thus the father and son quarreled because studs, Imitating Weary Roilly, had boen insolent. After much buoying of his bravado, he staged a hold-ap with his old rusty pistol, and was mocked by his victim. At two o'clock in the morning he was approached by his father at Fifty-Fighth Street.

\section{"B111?"}

\section{Studs stoppod.}

"Come on home, B1Il," the man sa1d with kindness. studs walked boside him.

"Bill, you don't ever want to be doing a thing like this again. Your mother's heartbroken." stude was glad to be going home.15

Stude felt only contempt and revulsion for his family. Ho soorned his father bocause of his inability to get to the point; boceuse of his habit of intending to do thinge rather than doing them, and because of the attitude he had toward the gouth's future, to go to school and get ahead. He decelved them whenever he deomed it convenient, kept them in the dark about his personal affairs, and tolerated them because of necessity, but kept them in the background. Toward his mother he

14. James 1. FarreII, The Young Manhood of Studs Lonigan (New York: The Modern IIbrary, Random Hous, Inc., 1938). p. 54.

15. Ibid., p. 60 . 
felt an impatience at her wanting him always to pray to see if he had a vocation and to do menial things around the house, dust rags, etc. His impulse was to get away from the house to avoid her nagging. Toward his sisters he felt contempt for their effort to live on a higher level than he, to attend high sohool and fraternity dances; toward his younger brother, Martin, he felt indifference. As an older brother, occasionally he felt it a duty to criticise his sisters' escorts and to warn Martin against drinking.

The daughters were solicitous that they associate with the right people, do the correct things, and that the family make a good appearance. They resented Studs' staging public scandals; Frances deplored a scene in which she and her escort met Studs on Christmas Eve, drunk and profane, and resentful of their offer to assist him home.

"Never as long as I live will I teel towards him again as a sister, or recognize that he is my brother!" Fran said with appropriate melodrama.

"After all I've done for children, and suffered!" the mother excleimed.

Fran went to her bedroom, and returnod with Studs' Christmas present of six pair of silk sto ckings.

"Till my dying dey I'll hate you $\cdot$ you $\cdot \dot{H}_{6}$ you. . brute!" she said, returning the present.i6 
The sisters resented studs' interference with them in any way, inconveniencing them, criticising their friends or anxious about their conduct, they feeling their own juagment to be superior to his. Studs and Fran were most always at odds with each other. 0ccasionally the sisters teased him in a patronizing manner; this exasperated him. Denny O'Neill, with a more detached attitude toward family, shuffled between the two families, the O'Nellls, his immediate family and the O'Flaherty's, his mother's family-making the best of uncontrollable situations and developing normally. Bill shows the influence of his proletarian parents; Danny falls under the more bourgeois influence of the grandmother's family.

Ilzz O'Nell1, Danny's mother, was a slovenly, gossipy, untidy housekeeper. She was over-zealously religious, attending church, going to confession, and praying; this devotion, however, did not lessen the caustic of her tongue. She delighted in attending wakes, remaining with the corpse several days if possible, gossiping with the mourners. She was an enthusiastic defender of her family, her motherhood, and her faith. 
Jim O'Ne1ll, Danny's father, a truck driver, and father of a large family, was proud of his family, resentful toward the O'Flaherty's, critical of hia wife, and inclined to drink; but on the whole was a more wholesome person than his wife. At the time of this third novel, pathex and son, the o'Nelll family enjoye more financial security than in the two preceding norels, due to the fact that Bill, the eldest son, was now working at the express company, also. Jim whipped the boys severely when he caught them swearing or misbeharing; he was bitter agasnst the poverty that made it necessary for Danny and Margaret to live with the O'Flaherty's, and he blamed Dr. Mike liorharty for the death of a son because of his refusel to come when called because of previous unpald bills. He was mildy religlous, given to occasional drunks, when he sought fights and boasted about them later; indignant at his wife's untidiness--he bought her dresses and cleaned the house himeself on numerous occasions; he was critical of her extravagance and exhorted her to save. He was tolerant and oncouraging toward Bill, prompting him to go to night school, now that he was working. The parental attitude of the O'Neill's torard Danny was varied. Iizz's attitude toward him was at 
times indifferent, possessive, protective and bosstful. She was exultant at his decision to study for the priesthood. Jim was contemptuous of the fact that Danny was becoming something of a dude, and cautioned him to get such notions out of his head. He felt that Danny should work during vacation and on Saturdays and givo part of his money to them; he was mildig congratulatory when Danny graduated from St. Patrick's and from St. Stanislaus High School.

Danny's attitude toward his parents was toleration, tinged with shame and evasion. Danny was ashamed of the poverty of the O'Neill family and of the roughness of his father.

Danny walked beside his father, clutching his diplomes. Papa was like some of the fathers of kide in the schools, with rough hands and rough skin on his face, but he was different from Glonn's father, and Roslyn's, and Billie's. They were all more like Uncle Al, business men and not like workingmen. I7

Again wo have this reflection:

Papa looked like a workingman. Many of the fathers of fellows at echool looked and dressed Iike business men. Whenever any one at school asked him what his father did, he always said his father was in charge of wagons and trucks at the express company, speaking of it in a way that made papa's job sound much bigger than it was. 18

17. James T. Farrell, Father and Son (New York: The Modern Library, 1940), p. 135 .

18. Ibid., p. 172 . 
Ho resented having his essociates see printed in the church paper that his father subscribod only one dollar while others gave one hundred dollars. He was cramped and 111 at esse when he was alone with his father or visiting at the O'Neill home. The O'Flaherty's wexe more financlally secure than the O'Neill's, and for that reason, Danng and his sister, Margaret, lived with them. The family was composed of Mother O'Flaherty, Aunt Margaret, Unole Al, Uncle Hed, and the two children.

The grandmother's chief weakness was drinking beer, and getting the crying jags. When Danny was smaller, he areaded these sprees, and was afrald whon we loft him alone to refill her pitcher with beer. She was watchful of other people's usage of things Al paid for; she nagged Margaret about her drunken sprees and about her lack of shame; she was a good housekeoper, Jealous of Danny's appearance and cleanliness, a tireless listener to marder stories in the newspaper and to Iizz's gossip.

Aunt Margaret was a nervous, irritable girl, a paramour of Larry hobinson, and an addict to drink to drown her gloom. She was the mother of an illegitimate Imbecile child by Larry kobinson, she had deserted her 
chureh, did not believe in God, resented Hed's unomployment, feeling that the weight of the family expense was on her shoulders, and sometimes fought With her mother while intoxicated. She was kind to Danny and Margaret, however, and often lavishod money and affection on them.

Unele Nod, living with the O'Plahorty's after the death of his wife, was inclined to be tolerant, but sometimes robuked Danny sharply. His unemploymont was a constant source of bickerings between him and Margaret. He had lagged in his religious faith; he believed that most things could bo accomplished by concentration.

Uncle $\Delta 1$ was a traveling shoo selesman. He was derout Catholic, a deroted supporter of his mother and her household, a peace-maker botween Irritated members of the family, and a jealous guardian of Danny's welfare. He shouldered a great responsibility and ald not shirk from his duty toward 1t. Though his means of self-improvement were meager, he read good ilterature, focusing his attention on words and ideas that would help him. He had plans for Danny's future; he felt toward him as he would toward a son. Ho, together with the others, resented Iiza's untidiness, 
her extravagance, and hor gossiping.

Danny's preference between his two homes was with the. O'Flaherty's. He had made that ohoice while st111 a child, when Jim O'NeIll had been foroed to rise late at night and take him homo to his grandmother, he cried so hard. Danny was ashamed of his Aunt Margaret's drunken oprees, afraid of the flghts botween his grandmother and Aunt Margaret, and fearful of disploasing Unclo Al; aside from this his home lifo was complacent.

Summary: (1) The Stads Lonigan trilogy portraye the disintegration of an immigrant Irish Catholic family under the influence of metropolitan I1fe; (2) the Danny O'No1II series portray botter integrated Irieh Cathol10 immigrant family, on a higher economio and social level, one closer to Farrell's orn family background, though atill dealing with poverty and all Its entaliments.

2. Ireatment of Ingtitutions

The troatment of institutions in the Studs Ionigan trilogy emphasizes aversion toward school, adherence to the church through fear, the predominanoe of the poolroom, and the ineffectiveness of the playground. In the Danny O'Neill trilogy the emphase is 
on Danny's interest in the athletics of sohool with

a more detached devotion to church, superifolal

interest in the poolroom, and a more genuine interest

in the playground.

The school was the least influential of the institutions with which Studs came in contact. Studs looked upon the parochial school a a jail; he made spiteful and sarcastic remarks about the sisters, and folt a cense of relesse when he was graduated. Whon his high school oducation was considered at home, he determined he was not going to high school and sought to extract a promise from his father to employ him in his basiness instead. Fnrolled at Iojola by compulsion, he played truant most of the jear and was subsequently taken in hand by his father and put to work in his buginess.

The church bond was a binding one in spite of the drunken, sex-ridden life Studs lod. It hold him through foar of death and by habit more than by any benefit to be derived in this 11fo. His devotion to the church was most always aroused after he had committed a sin or before a hazardous undertaking.

He thought of himself, out on the football field for tomorr on's gams. The kickoff. Studs Ionigan ranning the firat kickoff back a handred and three yards. He wasn't going to be hurt 
either. But suppose ho was. Well, he was going to confession so he wouldn't be. He'd be afraid to enter that game tomorrow if he didn't, because he had that kind of a feoling. 19

The poolroom wes the most influential fector of Studs Ionfgan'g 11fe. It was the meeting place of his gang, the place where empty and lewd gossip was engaged in, where the fellows got drunk, and primarily it was a place to spend idle time. The limsted moans of Studs' recreation, and his inclination to play the part of the hero and to be admired was the chief reason for his attachment to the poolroom.

He walked on towards the poolroom, wishing he was going out with Incy, a girl. Maybe they'd all go to \& can house. Ho was afrafd to do that; no, he wasn't. He smiled at Semmy Schmsitz the nowspaper man, hoping samm would comment on his now iid and clothes. Sammy was too busy selling papers.

Self-conscious, he joined a gang before the poolroom, and smiled deprecatingly when they kidded that he was all dolled up. Then they went back to kidding paulie Haggerty, the married man they said, who was too young to stand the gaff. 20

The poolroom had supplanted the playground in Stads: life as a meeting place for the gang. During the years previous to seventeen the gang had used the atreet and Washington Park to perpetrate its activities;

p. 110 .

19. Farrell, Young Manhood of Studs Lon1gan,

$$
\text { 20. Ibia., p. } 67 \text {. }
$$


play at sports, chase and fight with Jews and negroes, look for girls, or just walk around lazily, or sit and j1be.

The movie sometimes became a substitute for, or a consequence of the poolroom. It seemed to while the time away; however, it served an aditional purpose, which was to gratify the egotism of the youth. Studs Irequently pictured himself in the role of the hero, and soliloquized as to what he would have done under the same circumstances.

In contrast to studs' aversion to school, Danny O'Neill manifested great interest in school, especially in athletics. His scholarship standing had been lowered in fovor of athletics, and Father Michaol had reprimanded him for it.

"All sports and no study won't make you a bright boy, jou know. It will hamper you from gaining the benefits of schooling for which you are here. You are capable of doing much better in your studies than you have been doing. In your firet two years here your general average ranged between 85 and 90 ; this year it is ranging between 80 and 85. That would be very good for most pupils. But you have already proven you can be a 90 student." 21

This same negligent attitude was present whon he was thwarted in copying samuel Howard's Iatin homework but succeeded in copying Smilga'g. 
School athletics played an important part in Denny's adolescent life. Various attitudes were expressed in his family, and Danny was fearful lest they make him give it up. Jim O'Neill was opposed to it antil he thought there was a possibility of Danny's getting on a professional team and making money; his grandmother worried about the hypothetical doctor bill Al would have to pay if Danny got hurt; his Uncle Hod laughed at his self-deception when he sald he played for his school; and Uncle Al did not approve, although he did not atrenuously object.

The high school fraternity proffered to Danny his major social activities. The dances, al though they left him dejected at his inability to impress girlo, were onthusiastically attended, and the fraternity brothers, al though they were often only casually friendly, offered companionship.

Danny'g attitude toward the church was one of devotion tinged with hero-worship and intermingled with self-oriticism. His devotion and self-criticism are best illustrated by his attitude toward a vocation, after Sister Magdeline had talked to his class about entering the priesthood. When he talked to sister it was easy for him to feel that he had a call to be a. 
priest, bat when he was alone and thought of beooming a priest, a gloom settiod on him at not being able to marry or become a big leaguer; when he finally docided he was not cut out for the priesthood, ho folt a woight lifted off him, the lightness of elation. He liked to moditate on himself, however, as st. Dennis O'Ne111. When his Unclo Nod asked h1m why ho wanted to onter the priesthood, ho had no answer, and readily agreed with him that ho was not sulted to it.

His devotion, too, was often mingled with routine, as illustrated by his promise to God to say a dooade of the rosary for his Uncle Al's reoovery from his operation. His promlso was kopt, but the "hail marg's" were accompanied by thoughts of Roslyn and the perty both had recently attended.

His sincerity was somotimes gelf-convincing, oren though it was colored with personal attitudes.

He had to atop thinking of how ho would feel when he got it over with, and get on with the examination of his consolenoe. He was sorry for his 81ns, But was his sorr ow pure? He ought to be sorry for his ins beoause they offended God. But he was also sorry for his sins because in couple of minutes he had to acknowledge them to a priest; and somo of his sins were intimate and painfol.22

After his confession his falth in his redemption

22. IbId., p. 160 
from sin and in his religion is naive.

Danny ceme out of the confessional box, fooling as if he had actually lost welght. Yes, it was over. His soul was in the state of grace. He wished that he could take wings and tily. 23

His final attitude toward his school oducation

is summed up in the following:

He folt that there was something important in his high school career that was lacking. He did not know what it was, but he felt some lack, something important that was missing. And those four years, they were all gone now. Time was fast. Four years had gone and he had gotten so very little out of them. Porhaps it was his own fault. But he had expected so much more, dreamed of getting so much more, and all he had graduated with was a little faise glory. He had really been a failure in school, a fallure as a student, a fallure as an athlete, too.24

Summary: (1) For Studs Ionigan the important institution is the poolroom. He is a rebel against school and the church means nothing to him. (2) For Danny O'Neill there is a temporary spell of the priesthood. But the strongest influence is the school, particularly in opportunities for athletios and social 11fe.

3. Treatment of Associates

The treatment of associates in the Studs Ionigan trilogy hinges on gang intiluence; in the Danny o'Neill

$$
\begin{aligned}
& \text { 23. Ib1d., p. } 164 . \\
& \text { 24. Ib1d., p. } 570 .
\end{aligned}
$$


serles the emphasis is on school associates. The aspects of the gang influence are (I) its origin; (2) Its influence on studs; (3) his reaction toward it.

The final results of Studs' association with the gang was his doath in Judgment Day, caused from effects of pneumonia, contracted from a New Years' party arranged to bring the old gang together once again. At the close of the drunken, sex-infused celebration, Studs was found lying on the sidewalk in the snow in a drunken stupor and Weary Reills was arrested for assault and battery on his girl companion and later given a prison term; the girl Fictim was left a hopeless invalia.

The gang traces 1ts origin to days precoding and succoeding the graduation from st. Patrick's parochial school. The early amusements of its members were fighting Jews and negroes and each other; gathering some place and talking sex--sometimes including girls in these frank discussions; ongaging in sports in the park; stealing convenient objects auch as swimming suits or bananas; and playing truant from school. Iater these included collecting around the poolroom, shooting pool, drinking, exchanging. 
Instful stories, and making lewd remarks about the gex appeal of passing women.

Studs' association with the gang became so conguming that he became dependent upon them for h1s entertainment and recreation. He had no hobbies or interests with which to occupy himself when he was alone; he was always looking for someone to help him pass the time; most of his activities are presented in company with members of the gang. Under its influence he chewed tobacco, seoing how far he could expectorate, smoked cigarettes, fought for the pleasure of being terma a hero, was initiated in sexual intercourse, and played truant from high school for a whole term. $\mathbb{A}_{8}$ time passed he joined the poolroom crowd in its timewasting enterprise. The attitude of the gang outweighed any home influence; it fed his egoism.

His reaction to the gang was one of imitation, admiration, and desire for its approval of his performances. He was easily led by it; whaterer was suggested he welcomed; to try to join the army, go swimming, play baseball or football, go to a show, arink, go to the park, or just hang around the poolroom and gossip. He admired Weary Reilly's independent manner with hia parente; he applauded Kenny Killarney's witty rejoinders 
to everything he heard, and he liked to listen to the rulgar, obscene remarks de in the poolroom crowd. It was the influence of Weary Reilly and the bravado infused by the gang that caused him to defy his father, quarrel with him, and attempt a hold-up, armed with an old revolver. It was also to win their praise and gratify his own egotism that he fought and Whipped Weary Roilly; this fight remained in Stude' memory as an outstanding accomplishment as long as he lived. Other occasional associates were Danny O'Neill and Davey Cohen. Studs always regarded Danny as a "punk," and a sissy. Davey was a Jew, and was often embittered by being snubbed and reminded of his nationality.

With Danny O'Neill gang influence is negligible; his fraternity brothers and team-mates were more influential than the neighborhood group. The relationship between Denny and his fraternity brothers engendered inconsequential friction; neverthelese it persisted.

He had been reading in the papers about flaming jouth, modern yquth, jazz-age youth, and he was boginning to think he was missing something. He wanted to be flaming youth himself. That was Why yesterday at the basketball game ho'd told Hugh Molleill he wanted to get reinstated in the fraternity. He could learn to wear classy clothes and be as doggy 8 young fellows like Phil Rolfe 
and young Rocky who hung around the Greek poolroom at Fifty-Eighth Street. 25

Danny sometimes felt contemptuous of the boys who snubbed him, as he did for the condescending Glenn while ho was waiting to be reinstated in the fraternity; and sometimes he felt dejected, as when they falled to include him in their groups at the froternity dance. But his relationship with them improved somewhat, as evidenced by his and Natelle's going with Red Keene, and Ike Dugan in Red's old Ford to the second fraternity dance. He chummed with members of the fraternity at various times, but always seemed to be an outsider, or was a butt for their teasing.

In athletics he became a good football player and was captain of his team, but the boys lacked the proper respect for him and paid little heod to his comments or suggestions.

A comprehensive view of his associatione is that he is accepted by other boys, and liked, possibly because he is good at sports, or because he is a good target for their jokes. Proofs of this attitude are his captaincy of his team, his reinstatement in the Iraternity, his picture in the paper because of out-. 
standing athletic performance, and the request for a speech from him at the football banquet.

His attitude toward his fraternity brothers was solicitous--a desire to be approved, to be included in their group, to dance as gracefully as others, and to be popalar. A puerile envy consumed him when these desires were frustrated.

His contact with the neighborhood gang was only occasional. Their treatment of him was ironioally contemptuous.

Danny stood by himself in front of the poolroom, wondering what to do. Studs Ionigan and a fow of the older fellows were grouped together a fow paces away from him.

"Hey, O'Ne1ll, you better let it alone. You don't want to go to the booby hatch, do jou?" $S$ tuds Lonlgan jelled at him.

"Yoh, O'Nelll, gou ain't got them pimples on jour face for nothing," Big SIug Mason said.

Danny walked by them without saying a word, hearing them laugh. The big bastardsi Studs Ionigan used to like him when he was a punk. Now Studs hardly ever spoke to him, except to make some wisecrack at his expense.26

Summary: (1) In Studs wo have in fictional form one of the fullest studies of the influence of gang life upon modern youth. In Danny O'Neill the influence of the fraternity and its associations is studied. (2) Both 
emphasize typical rathor than porsonal associations.

\section{Treatment of Sex}

The treatment of sex in the Studs Ionigan

series hinges on Stude' obsession with sex. In the

Danny O'Neill series it hinges on Danng's fear of girls of his own class accompanied by a freor disposition toward girls of looser morals.

Studs Ionigan is an over-sexed boj and he continues to be so through the trilog, which covers his Iife from about fourteen until his death in his early thirties.

They walked on along the tennis courts on south Park Avenue, talking away. Studs didn't listen to thom. He thought of Iris. He prayed that ho would get her soon. He had to, because he couldn't think of anything else these days; and even that shutter trick woulan't work to get the thought out of his mind.27

This quotation is typiosl of Studs' attitude toward sex throughout the volume.

The enumeration of his thoughts on sex exceed the actual sex experiences. His sex thoughts involve his sister, Frances, when ape appeared before him in a thin chemise; 28 Helen shires, when she tells him of the "can house" about which she had learned and of

27. Farrell, Young Ionigan, p. 178.

28. Ibid., p. 62 . 
Weary Rell2y's advances to her; 29 the "Bhow-party, "30 staged by a group of younger children including Helon Shires' sister; the old woman against wham he was jammed on a crowded $01 ;^{31}$ the "broads" he met in the park or in a restaurant, or saw passing the poolroom. 32

H16 actual sex experienoes involve Iris, a girl about fourteen; ${ }^{33}$ Elizabeth Burns whom he pioked up in Washington Park, whose father followed her and chased Stude with a horse whip; 34 the girls at the Now Year's party. 36 and the married woman ploked up in Phil Rolfe's--now his brother-in-law--bookmaker quarters.36 The early effect of his sex thoughts or acts was feeling of remorse, a feeling that he had committed sin, and he prajed for forgiveness or went

29. IbId., 800. II, p. 15 .

30. Ib1d., p. 106. p. 31 .

31. Farre11, Young Manho od of Studs Ionigan,

32. Ibid., p. 298.

33. Farre11, Young Lonigan, p. 180.

34. Farrell, Young Manhood of Studs Lonigan. p. 81 .

35. Ibla.. p. 406.

36. Farre11, Judgment Der, p. 236. 
to confession. This attitude was repeated as he grew older, although with 1088 frequenoy.

At home, Stude' conscience bothered him, and he still worried lest Iris would snitoh. But there was nothing to do, unless he wanted to be a damn fool and sp1ll the beans. He tried to pray, promising the Blessed Virgin that ho would't neter fall into in like that again, and he'd go to confession, and after this he'd 80 onco anth and make the nine first Fridgye. But he couldn't concontrate on his prayers. 37

The feminine attitude most frequentiy expressed was a willingness to yield but a fear of the consequences.

The results of his unoontrolled sex urge was the 108s of Irey Scanlan, 38 wi th whom he had been in love sinoe early adolescence, and the ruin of catherino, 39 the girl whom he was expecting to marry. Iucy resented and repelied h1s adrances on the way from the fraternity dance, and cleverly escaped him when she reached home, but would nover risk making another ongagement. Catherine, jielding herself to him in a moment of tenderness fter a quarrel, was left pregnant at the time of his death, to bear the fate of an unmarried mother with an illegal child.

\footnotetext{
37. rarre11, Young Lonigan, p. 189. p. 298 .

38. Farrel1, Young Manhood of Studs Ionlgan,

39. Farre11, Judgment Day, p. 417.
} 
In contrast to studa' obsession with sex and his Ireodom with girls, Danny found girls an enigme and was only casually interested in sex. This interest was two-8ided: (I) he wos concernod chlefly with the impressions he made on girls of his own group; (2) he showed the usual interest in "pick-ups" in the park.

He was not a success with girls socially; he found it diffioult to secure a second engegement. He was at a loss for conversation when talking to them and was unable to express the things he wanted to say. Most of his remarks consisted of the platitudinous queation and answer arrangement. Being a poor dancer, he stepped on girls' toes at fraternity dences and thus falled to reap the benefits due an adept at thi social diversion.

"Would you like to dance?" Danny asked, sitting beside Anne.

"No, thanks, I'm tirod."

Some couples were dancing, and others, including Mike Flood and harty, were standing a fow feet awey in a gay and laughing group. None of then turned to ask Anna and him to join them. AIl night, most of his fraternity brothers had scarcely paid the slightest attention to him. 40

His attempt to impress Natalie at another

40. Farrell, Pather and Son, p. 247. 
fraternity dance ended as futilely. His 1magination built beautiful romantic dreams around the girle he liked, but he was never able to express these thoughts aloud.

The park wes quiet. Eron the wind soemed romantic. Here he was, doing what he had hoped and dreamed of doing, going to parties, taking a girl home in a cab, and tomorrow getting his chance to be a lootball hero. And still it wasn't like he had hoped it would bo.

\section{he said. \\ "Tommy Collins was to Ireland this sumer,"}

"Yes, I heard ho was. It must be fun to

If only he could say to her, wouldn't it be fun if he and she were married and could travel to Ireland and all around the world on honeymoon, and make love in the moonlight on a sip in the midale of the ocean. 41

With the girls he met in the park he felt froer, and although the affair turnod out to be only a lark, he was able to express himself better. After roughly kissing his "piok-up" and boing repulsed in more intimate advances they joined the other couple, sitting on bench. The following scene dereloped.

Danny led his pick-ap into the Japanese house, and stood in a corner with her. He embreced her.

$$
\text { "Don't." }
$$

41. Ibia., p. 870. 
"Why?" he asked, his voice a trifle husky.

"We'll be seen."

He roughly pulled her to him and kissed her. It was his first kiss since he had been in the eighth grade. The contact emboldened him, drove him on, excited him with desire . . . . . .

"Iet's go back," he said, walking beside hér on the path away from the Japanese house.

"No."

"Why?"

She dian't answer him. He linked his arm in hers and they strolled on ...........

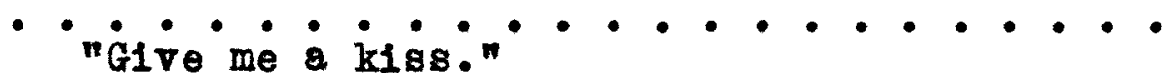

"Not in pablic."

"There's no one around."

"It's not nice. I don't even know your name."

"Sam. Just call mo Sam."

"I don't believe it's sam."

He grabbed her and tried to kiss hor.

- "You're rough," she said, laughing and freeing herself from him.

"Iet's go in the bushes," he seid.

She giggled.

"Come on," he said, grabbing her again.

She pushed him away. 42 
Sumary: (1) Stude is obsessed with thoughts of sex-indulgence; Danny is more interested in the social side of sex and in friondship with girls; (2) Stude is intiated early into sex-experience; (3) studs recognizes no barriers to sex advances; Danny refrains from making advances to girls of his own social strata but is freer with girls of a lower social level; (4) Danny has the adolescent fiear of women emphasized by the other authors.

\section{CONCLUSION}

In view of the foregoing the following conelu- Lons can be drawn: (1) Young Lonigan is not autoblographical; it is a tragic character-type study of the author's generation; (2) it is historical in that it shows some of the vicious tendencies of his ers; (a) the extensive arinking that characterized the prohibition era; (b) the moral let-down in regard to sex; (c) the break-down of the school, the church, and the pleyground; (3) the portreyal of the dissipation of youth Indicates the anthor's detached observance of the social sceno; (4) the Danny O'Neill serles are autobiographical; the author's attitude toward adolescence is that normal response to church, school and family influence produce a wholesome adolescent. 
CONCIUSIONS

The analysis presented in these chapters points to the following conclusions:

(1) Five of the novels disonssed are autobiographical, and the sixth one is biographical. The five are portraits of the artists as youths. This tendency toward autobiography in fiction is a characteristic of the period following the World war--a rebellion against the repression of individualism that has characterized the machine age.

(2) In contrast to Mark Twain or Booth Tarkington these younger writers are interested in those forces that shape the artist in his yoath: famliy, institutions, essociates, and sex.

(3) The treatment of family brings out (a) emphasis on hereditary strains, (b) reaction against the family 2.8 more of a hindrance than an aid to the Jouthful artist: exceptions to this general pattem are the attempts of Dell, Wolfe, and Fisher to herolze the father, and of Fitzgerald to romanticize the mother. (4) The treatment of institutions emphesized the influence of schools in contrast to that of the church. Vardis Fisher is influenced by the tradition of Biblereading and Fitzgerald by a churchman rather than by 
the church. All the authors with the exception of Dell have lald emphasis on schools as a means of achiering their goale, and even he pays tribute to their influence to a large extent. In the tragio case of stade Lonigan the most potent institution was the poolroom.

5. Associates are treated in terms of their aid to the personal and artistic derelopment of the heroes. There are authors, journalists, and socialists with De11; schoolmates and a churchman with Fitzgerald; and sohoolmates with Farrell in Danny O'Neill. Wolfe, however, emphasizes the aloofness of his hero and Fisher the scarcity and hostility of associates on the frontier. In the tragic case of Farrell's Stude Ionigan, it is the gang.

6. The most striking now problem for these writers is that of sex. All of them deal with it, Fitzgerald more reticently, the rest very outepokenly. A recurring theme is adolescent fear of women with variations in individual experience. There is great omphasis on mental preoccupation with sex and a strong tendency to present realistically sexual experienoe. All in all these fictional treatments of outstanding youths give a great deal of insight into the minds of 
modern youth.

The trend of fiction, after the Forld Var, as 1llustrated by these authors, is toward a more realistic and naturalistic portrayal of adolescence. Mark Twain wrote about adrenture in Huokleberry Finn and in Tom Sawror, giving the atmosphere a romantic and heroic color. Booth Tarkington showed the same romentic tendency in Seventeen even though his novel described in a Indicrous and humorous manner the struggles of adolescence; his attitude was sympathetic even though amused. The post-war authors portray life out of their own experiences without attempting to soften the outline. 
BIBLIOGRAPHY

,

,

1 


\section{BIBLIOGRAPHY}

\section{A. BOOKs}

Anderson, Sherwood, Tar. How York: Albert and Charles Bon1, 1926. 346 Pp.

Benet, Stephen Vinoent, The Beginning of Fisdom. Hew York: Holt Company, Ist2. $359 \mathrm{pp}$.

Young People's pride. How York: Henry Holt and company, I9k2. 500 pp.

Bishop, John Pealo, Act of Darkness. Hew York: Charles soribner's Sons, $1985.668 \mathrm{pP}$.

Bronson, F. N., Spring Running, Hew York: George H. Doran Company, 1926. 306 pp.

Brown, Rollo Welter, Toward Romance. Now York: CowardMovann Company, 1932. 379 pp.

Carr, Robert S., Rampant Age. Now York: Doubleday, Doran and Compang, I9t8. $880 \mathrm{pp}$.

Craven, J. V., The Leaf is Green. New York: Alfred A. Knopl company, I98I. 236 pp.

Coffin, Robert Tristram, Fost Paradise. Hew York:

The Haomilan company, 1984. 284 pp.

Rea Sky in the Morming. New York: The Iromitisn Company, $1985.288 \mathrm{pp}$.

Dell, Floyd, Moon-Calf. How York: Alfred A. Knopl Company, 1920. 394 pp.

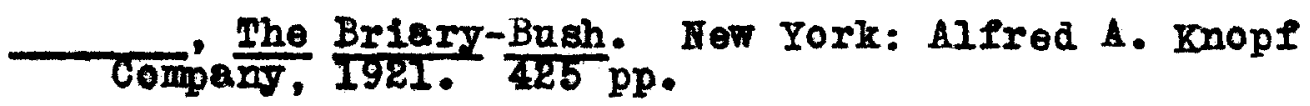

I985. $\frac{\text { Homecoming. Hew York: Farrar and Rinehart, }}{368 \text { pp. }}$

Draiser, Theodore, An American Tragedy. Now York: Bonl and Iiveright, 1926. 2 v018.409, $431 \mathrm{pp}$.

Perre11, Jams T., Young Ion 1gan. New York: The Hodern

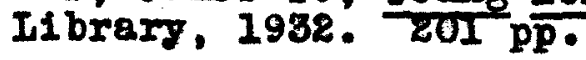


Young Manhood of Studs Lon1gan. Hor York:

The vodorn Hibrary, I934. 4II Pp.

I935: Judgment Dar, New York: The Hodern Ifbrary,

, A Forld I Never Wede. Hew York: The Vanguard

PYQ88, 1936. 516 pp.

I938. ${ }_{63} \frac{\text { Star }}{3 \%}$ 18 Lost. Hew York: The Vanguard Pres,

Tgzó Father and Son. Hew York: The Vanguard Press,

Ploher, Varaie, In Tregic Iffe. Caldwell, Idaho: Tho

certon Printers, 1962. 464 pp.

- Parsions Spin the Plot. Iew York: Doubleday, Doran and Company, 1934. $428 \mathrm{pp.}$

- We are Betrezed. New York: Doubleday, Doran and company, 1935. 369 pp.

- Ho Fillain Hoed Be. HeV York: Doubleday, Doran क्वd' company, 1936. 881 pp.

F1tzgerald, Francig S. K. This S1de of paradise. Now York: Charlos Scribner'

- The Beautital and the Demned. Hew York:

Cheries Scribner's Song, 192\%. $49 \mathrm{pp}$.

Poote, J. T., Change of Idols. New York: D. AppletonContury Company, 1936. 52 pp.

Friesen, Gordon, Flamethrowers. Caldwell, Idaho: The Caxton Brinter8, 1936. 490 pp.

Granberry, Bdwin, Erl King. How York: The Macaulay Company, $1930.285 \mathrm{pp}$.

H111, Fowler, Plundered Host. New York: E. P. Dutton Company, 1929. $270 \mathrm{pp}$.

Horgan, Paul, A Iamp on the Plains. New York and London: Harper and brothe ro Company, 1937. 373 pp. 
Johnson, Alvin Seunders, Springstorm. New York: Alfred A. Knope Company, 1986. 35I pp.

Johnson, 0. M., Sklppr Bedel1. Boston: Iittle, Brown and Company, 1922. $616 \mathrm{pp}$.

Joseph, Donald, Oetober's Child. Now York: Froderick $A$. Stokes Company, 1929. 344 pp.

Eiretern, Linooln, Flesh is Holr. New York: Brewer Warren and Putnam Company, I932. 311 pp.

Iunitz, Stanley J., Authors Ioday and Yeaterday. New York: The H. T. WIIson compeng, I933. pp. 239-241.

Ialng, Alexander Kinnon, Frad of Roaming. How York: Farrax and Rinohart, 1930. $384 \mathrm{pp}$.

Ioe, Harry, pox in the Cloak. How Jork: The Macmilian Company, 1938. 66r pp.

Low1s, Flannery, Abel Dayton. New York: The Nacmilian Company, $1939.304 \mathrm{pp}$.

Iindsay, Hormen, Every Mother's Son. INoF York:

Cosmopoliten Book Corporation, 1930. $352 \mathrm{pp.}$

Meolullan, Hugh, Louder than Words. Iow York: Loring and Mussey Company, 1985. $288 \mathrm{pp}$.

Marks, Percy, A Mree Grown straight. New York: Frederiok A. Stokब Company, 1936. 339 pp.

Masters, Edgar Lee, Mitch Miller. Hew York: The Maomilian Company, 1920. 262 pp.

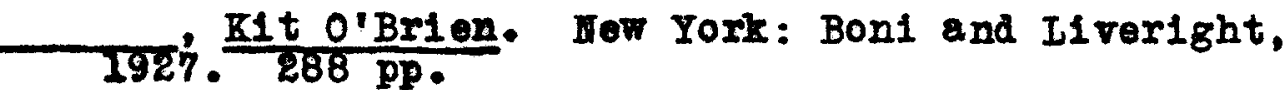

MAllett, Fred B., Contemporary American Authore. New Yorix: Harcourt Brace and Company, 1940. TI6 pp.

Price, Bmerson, Inn of thet Journey. Caldwell, Idaho: The caxton Printers, 1939. $266 \mathrm{pp}$.

Rolline, William, The Obeligk. New York: Brewer and Varren Company, 1980. $419 \mathrm{pp}$. 
Samue 10, Charles, Frantio Young Man. Hew York: CowardMocann Company, 1989. 289 p.

Stephonson, Philip, The Gospel According to St. Luke'g. Iow York: Iongmañ, Greon and Company, $1981.388 \mathrm{pp}$.

Stong, Phtlip, The Fong Iane. Hew York: Farrar and Rinehart, 1989.308 pp.

Toohey, John Poter, Growing Paing. New York: The Dial Pres8, 1929. 312 pp.

Vlertel, Poter, the Canyon. Hew York: Hareourt, Brace, and Company, 1940. $299 \mathrm{pp}$.

Ware, E., Rider in the Sun. Boston: Lothrop, Iee and shopard Company, 1936. 197 pp.

Webster, Henry Kitchell, The Innocente. Indienapolis: The Bobbs-Merrill Company, 1924. 346 pp.

Wickenden, Dan, The Running of the Deer. New York:

Wiliiam korrow and Company, 193\%. $343 \mathrm{pp}$.

, Fell Iike a Mortal. How York: Will1am Morrow and company, $1970.530 \mathrm{pp}$.

Winter, J. K., Other Man'g Saucer. Nev York: Doubleday, Doran and company, 1930. 308 pp.

Wolf, Robert I., Springboerd. Now York: Albert and Charles Bon1, 1927. 274 pp.

Wolfe, Thomas Clayton, Look Homeward Angel. WeW York: The Macmilian Compañy, 1929.626 pp.

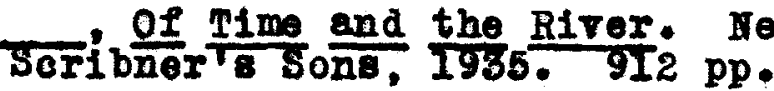

You Can't Go Home Again. Hew York and London: Harper and Brothers, 1934. $743 \mathrm{pp}$.

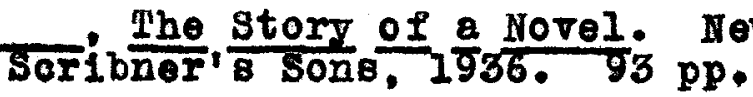




\section{B. PERIODICAI ARTICLES}

Basso, Hamilton, "Thomas Wolfe, a Portrait," HeW Republic (June 24, 1936), 199-202.

Bates, Ernoet S., "Thomes Wolfe," Jnglish Journel (Septomber, 1937), 519-527.

Bierney, Farle, "The fiction of James $\mathrm{T}$. Parrell," Canedian Forum (Apri1, 1939), 21-24.

Bishop, John Peale, "The Missing All," Virginis Quarterly Revier (January, 1937), 107-21.

"The Strange case of Vardis Floher," Southern Eevion (Autumn, 1937), 348-359.

Bridges, Ann P., "Thomas Wolfe, Iegends of a Man's Hunger in his Youth," Saturdar kovier of Iltorature (April 6, 1985), 599, 609.

Cowley, Malcolm, "Of clooks and lalendars," The Ner Ropabl10 (March 17, 1941), 376.

Deniels, Jonathan, "Thomas Wolfe," Daturday Revier of Iiterature (September 24, 1938), 8 .

Fadiman, "lifton, "Thomas Wolfe," New Yorker (March 9, 1985), 68-70.

Farrell, James T., "A Novelist Begins," Atlantic Monthly (September 2938), 330-334.

"Ployd Del1," American Bookman (March 1923), 65-71.

"Francis Scott Key itiggerald," American Bookman (March 1922), 20-25.

Glicksberg, Charles I., "Contemporary Uriticism," South Atlantic Quarterly (Octobor 1936), 455-457.

Iowis, Sinolair, "Floyd Doll," American Bookman (May 1921), 245.

Lovett, Robert M., "James T. Farrell," Mnglish Journal (May 1937), 347-54. 
Macauley, Tharston, "Thomas Wolfe, a Writer'g Problems," Publisher's Weekly (December 24, 1938), 2150-2152.

McCole, Camille J., "Thomas Wolfe Kmbraces Iffe," Catholic Worla (April 1936), 42-48.

O'Hara, John, "In Memory of Soott pitzgerald:II," The Now Republic (March 3, 1941), 311.

Stephens, teorge, "Alway: Looking Homeward," Saturday Rev10w of iiterature (June 24, 1939), 5-6.

Wade, John Donald, "Prodigal," Southern Rovier (July 1935), 192-198.

Warren, Robert Penn, "A Hote on the Hamlet of Thomes Tolfo," Amerioan Revier (May 1935), 191-208.

Vilson, Edmund, "Imaginary Conversations, Mr. Van Fyck Brooks and Mr. Scott Fitzgerald," Hew Yorker (Apr11 30, 1924), 249-254. 
APPERDIX 


\section{APPENDIX}

Analgsis of Horels of Adolescent Iffe 1920-1940

The following list of norels was obtained from the Book Rerlor D1gest, 1920-1940.

DATE TITHE

1920 Noon-Calf

The analysis of this novel is given in Chapter I, page 1 .

1920

Th18 side of Paradise
AUTHOR

Plojd Dell (1887-)

The analysis of this novel is given in Chapter II, page 30 .

1920 Mtoh Mllor

Bdgar Lee Masters (1868-)

3keotg Kirby and Mitch Miller bocame friends and adventurers. They observed a Iight between Jack Plunkett and Rudy Hedgepath to see who was the best man, ther dug for treasure in Montgomerg's woods, discovered Nancy Allen's treasure in the -ollar of the Bender house and they started on a journey to soe Tom sawyer. They mero key witnessea in tho Doc Iyon murder trial and also in the Temple Soott-Joe Rainey muraer trial. The fathers of the two boys took them to seo rom sawyer, a fat butoher in Hannibal; Mitch's disilinsion was unbearable. He was injured fatally hopping frelght care.

Mitoh Miller is a novel of adventure similar to Mark Twa 1 's lom Sarror. It is loss romantio in that it represents Iom Sewyer as an unheroio butcher.

1921 The Beginning of Figdom Stephen Vincent Benet (1898-)

Philip Sollaby, a native of California, spent 
most of his early lifo in boarding ochool. it Yale ho mot killie, daughtor of a shoddy dontist, fell in love with, and married her. She died soon afterward from pneumonis. He tried to join the Royel Air Force in Canade, was refused booanse of tuberculosis, and wont wost to recover. He became involved in an I.T.W. strike and went home to California, whore he quarreled with his father and loft for Los Angeles. He got into the movies, was operated on successfully for his tubercular troubie, joined the army and was about to be sent orer whon the armistice was signed. He returnod to Callfornia and married his cousin, sylvia.

This novel is autobiographical, featuring an I.D.N. etrike in Hevade.

1981 The Briary-Bugh Floya Dell (1887-)

This norel is the sequel to Moon-calf. Felix Fay quit the "Hors" in Port Royal and went to chicago where he got a job on the "Chronicle," met Rose-Ann and married her. To enoourege Follx to write, his wife persuaded him to rent a room apart. Here he mot Phyllis, an acquaintanoe, and thought ho was in love with her. He and Rose-Ann quarreled about hor, and she went home. When ahe returned, the gazino publishing house for which she worked moved to California. Folix had an affair with a Iittio Theater actress, Elva, decided to go to Californis to seo about having his play produoed, mot Rose-Ann and they became roconotied.

Briary-Bush is autobiographical and continues the story of Felix Fay's iffe through young manhood and the carly part of his marriage.

1922 The Beautiful and the Damed Scott Fitrgerald (1896-)

Anthony Patch, grandson of a multi-millionaire, lod $a$ wild and aimiess lifo. At twenty-fire he met and married a beautiful girl. They lod a fest 11fe, and he was disinherited by his grandfather; in the ond the court restored his grandfather' fortuno to him, but he was a physical and montel Trock. 
This notel emphas1zes the extravagances of a woalthy young man immediately precoding and during the early jears of marriage.

1928 Young Peoplo's pride Stephen Vincont Bonet (1898-)

0l1ver Crowe broke his engagement with Nanoy because sho was more successful than he in obtaining satisfactory employment. At a house party at Peter Piper's ho persuaded Elinor, Poter's sister, to marry his friend Tod Biliott and rescued Ted from an ombarrassing situation w1th Wrs. Severance, an attractive w1dow, where Mr. Piper, Poter's and Elinor's fether was inrolved. He beceme reconolled with renoy and after their marriage they sailed for paris whore he was to assume a position with the Amorican Express.

This novel features the quarrel of an engaged couple, Interweaving ano ther romance and the liason between an elderly married man and a young attractive widow.

1928 Sk1ppy Bede11 $\quad$ 0. 1. Johnson (1878-)

Skippy and his roommete, Snorky, survive meny strange inventions, the fruit of the fertile Imagination of Ur. Johnson's youtheal hero; they fall in lore; they wear their first dress-sults, they quarrel and make up and 80 through various other nnfailingly amusing vicissitudes. Mre. Johnson rivals Booth Tarkington at his best in some passages of SkIppy' his tory, and the book belonge pretty olose to serenteen in entertainment.

Skippr Bedell is about the boarding-school opisodes of two youths who jump from one entanglement to another.

An Amorican Tragedy Theodore Dreiser (2871-)

In this novel Theodore Drelser presents the story of a moral coward. The jouth, son of poor mission parents, obtains employment in a hotel. 
In compeny with some other bell-hope he enjoja an excursion in a stolon car, the run down a child, and he has to floe. In another city. omplojed in a hotel, ho moots his moalthy unole, who oventually gires him employment in his factory. At the factory he beoomes infatuated with a girl and soduces hor. In the meantime he has met a girl of his unclo's social oirclo who leads him on. He plans to murder the pregnant girl; her body 18 found, he is tried, found gailty, and electrocuted. The first volume deals With his youth, the second with the crime and its punishment.

The novel is blographical and features youth in orime and 1 ts panishment.

1926 Spring Ruming F. N. Bronson (-.-)

Charles Hammar is attracted to Doborah stirling in chlldhood. When his father dies and his mother remarries he is comforted by irs. Stirling. Deborah considers becoming a nun but changes her mind. As a jouth, stajing with his sister, Regis, in Iow York, ho otudies for college exame but fails to pass. He worked at various jobs, then mot Irone Gilbeg, manager of a book store. After Irequent engagements, they become engaged, and he persuaded her to leate her omplojer, Mr. Drain, with whom she had aditted being familiax. He went to his mother to ask for money to open a book store, and returning, found her with Mr. Drain. At $R_{\theta g}$ s' $^{\prime}$ 'vedaing he mot Doborah again, not courted by a handsome young man. Jim Bireh. Boturning to Halcyon with her; he sponsored a campaign to get a now road built. He worked so hard ho began to cough; Doborah had agreed to marry him, but feeling ho was not being falr to hor to marry in his condition, he rent west without telilng her. She followed him to the Flying-Q Ranoh.

This novel is blographical and features the episodes and 10ve affairs of the youth, onding with his return to his childhood love.

2926 The Iniocents

Henry Kltohell Webster (1875-)

Bdward Patterson was interested in inventing 
an attachment for a phonograph to convert it into a radio. It was sucoessful; through Agathe 1liard ho got an order to attaoh his invention to the rillard phonograph and stayed at the Willard home during the enmmer. Yany other orders followed. Fdward had love affair with the school teroher who wes governess to the Wiliard twins, but in the ond he turned back to Agatha. Harital trouble between the patterson olders was also solred setisfactorily.

The Innocents interweaves a boy's invention, a youthin romanco, and reconciliation of his parents into the space of one summer.

Tar Hoorehead, son of a southerner, was reared in ohio. His father, a harness-maker, had fought in the civil War for the North; he was a great story teller and ontertainer. The family bocame poorer and poorer, and moved from place to place. Tar, through brarado, out-butted the champion butter, vieited the race-horse farm of Tom Whitehead on sundeys, fell in love with sither rarley, was loved in turn by Mary Thompson, and sold papers. His mother died, and with her death he roalized he was leaving his childhood behind and entering adolescence.

Tex is centered around the childhood of Tar Moorehead, is biographical, and portrays tho childhood episodes of a boy in a small ohio town.

1927 Springboard Robert I. Wolf (-.-.)

Brian Hart was the son of a rallroad magnate. The Hart family moved from Chicago to cleveland, ohio. At sohool Brion was bullied and nicknamed "Foirly" because ho hed said he plajed tennis fairly well. His father wanted him to tudy Iaw; he preferred journalism. At Harvard he was snubbed by a man, Ionsdale, whom the boy liked very much; he made Iriends with Eric camden, and they argued all questions at all times. At times his father was appalled at his views. He became enamoured of Doliy MacGean and worked the next sumer on her father' paper; he met Mary Dixon Gillet to the next year; they became engaged and 
married; he was offered a position in the university as instructor and socopted it.

Springboard is blographical and hinges on father-Bon antagonism. The boy's final decialon to become a college instructor instodd of a lewyer, his father's chosen profession for him, is the climax.

1927 Eit O'Brien Bdgar Lee Masters (1868-)

Kit O'Brien is liable to arrest for stealing a pie. He, weorge Heigold, and Charley zing wore on their way to st. Iouis to get work whon the pie was taken. The other two were canght and arrested; IrIt escaped and got to St. Iouls. Ho succeodod in rescuing Mise siddons from her insane hubbend and bringing her beck to Potersburg, her home. George Montgomery, with Hardy K1rby's belp, succeoded in putting Miss Siddon's husband, "Master," in the insene asylum and extricating the boys from their entanglements.

Ilt O'Brien is a sequel to Mitoh Miller and foetries the adventures of Kit O'Brien and the arrest of the three friends of Mitch Miller for stoaling a pio.

1928 Rampent Age , Robert 8. Carr (1909-)

Paul Benton, moving from the small town of Nestileld to a larger town, gets in with the high school's wild set. on a date with ritzie, he runs down an old man on an ley street and does not sop. He really I1kes Doris Bulen, a quiet decorous girl, bat Fritzie holds him through hor knowledge of the accident. Happening on another accident in which Doris was involved, he took her in his car to the doctor in the nearest town. The doctor recognized Paul as the hit-and-run driver whose car had struck him. He had him arrested, but Paul's fathor proved a Iriend in need and extricated him. His first cholce of a college had been a flashy one, Brighton 0 ; his last cholce ander the influence of $\mathrm{Mr}$. Buien was Abbott, a more reserved, soholerly one.

Rampant Age 1s bailt around the adolescent age and group. 
1929 Iook Homeward Angel Thoma Wolfe (19001938)

For the analyeis of this novel seo Chapter III, P. 68 .

1929 Ootober's Child Donald Joseph (-.--)

Ineins Deering spends his chlldhood living with his mother, a widor, and his Uncle lenny, who is wild and unsettled. The edolescent stage is reached at the time of Eleanor Overton's vioit--invited by Mrs. Deering in hopes that she would cepture and marry Uncle Ianny. Iucla onter college, makes Iriends with Julien Danoan, Who becomes his roommate, and with Kay Merrill. His relation with these two is, on the whole, congenial. After the Christmas holldays his mother writes to him that she 18 golng to marry Mr. Pendleton, her attorney. Other letters inform him that the wodding has taken place, that sho has accompanied $\mathrm{Mr}$. Pondleton to Philadelphia for an operation and taken cold. An illness keeps Iucius in a delirium for a woek. Whon he bocomea himself he is informed his mother has died. He leaves college to recuperate with his aunte st IIto Oak Farm.

October's Chila is a blographical novel projecting the reactions of a sensitive youth to the opisodes of his life.

1929 Plundered Host Fowler Hill (-.-)

Poter Brush lived with his aunt Rebeoca Henderson in Hew York. Vacations were spent on the country estate at Stocirton. When Peter was roady for oollege his aut announced thet she had sold stockton, and that peter was to spend his racation working in a ractory at Akron. Ho liked the workers and especially Peggy. At college he foined a fraternity but decided he would rather be with the rough crowd. Tom Wilson introduced him to the undecorous women across the river. Home in Hew York, upon the death ot his Iather, he wandered, in a drunken atupor, through a gate in a quiet street and entered the room of an artist. They ceme to know and to depend on each other and were married. 
This is a biographical novel and consiste chiefly of the impressions made upon peter by all the thinge with which he came in contact.

Frant1c Young Man

Charles Samuels $(-\infty-)$

Arthur Gordon 18 sensitive becanse he is stili virgin. He attempts to cover up this fact if th other boys by posing as a person of numerous sex experiences. He attempts to overcowe this handicap by getting Tess of the Bronx intoxicated, only to find that Tese cen stand more Ilquor than he, and he became intoxicated tirst. He held jobs as clerk, nenspeper reporter, advertiser, and sales promoter. Accoptanoe of a story gave him aspirations to write. In Florida an attempt to make Iriends with sylvia was Iutile, but with her roommate, Mrs. Hricson, ho was more sucoessiul; ho lost his virginity. Returning to Hew York, he intended to flout his acoomplishment betore his ledy triends but found Tess awey on a trip to Europe, Vera married, and Mlldred reconclied with her hasband and expocting a baby.

This novel deels with young manhood and emphesizes the efforts of a young man to lose his virginity.

Wilbur Jones escaped Irom one dilemma, only to Iall into another. His Iirst was a love atiair with an actress Irom which he was extricated by h1s Iether. Then he became a champion exposer ot communist meetings, summoning the chief of police to the boat clab where the members were found innocently dancing. Then he persuaded his mother to sell their car to help him pay a gambling debt of honor, telling the rether that the car had been stolen. The climax came when the tather recognized the car in another town, became involved in an argument and landed in jail. The car was recovered. In the end he begins to show more practicel judgment.

Growing Pains is similar to Booth lerkington's Serenteen in that it presents the episodes in which the jouth becomes involved as ludicrous and humorous. 
The Obelisk is a novel in which a story of the Obellak has 1 mpressed Iouls Rang so much that the impression reaches into adulthood. the grandmo ther tells him of the obelisk in the Forest of rontainblean from which roads load in all directions; he always has a desire to $\mathrm{g}^{\circ}$ there. He meets an artist by chance, visite her regulariy, and they plan to go to surope to visit the obelisk. He deters his plans until it is too late, and marries a girl chosen by his Iamily; one day he recoives a eard without any signature but with a marble slab in the center surrounded by trees from which three roads led away. He recognized the 1mport of the card. After abotraotediy watching the boats in the harbor, he returned to his routine duties.

The Obelisk is a blographical novel that portrays a youth as a dreamer, lacking the urgo to go forth and realize his dreams.

Richard Melveille admired his Uncle Robert, Who had poetic tendenoles without much cesh, and of whom the Iather, Goorge, did not epprove. After a quarrel the uncle lett and was lost at se8. At sohool Richard exploded stink bombs to get the school a hollday to see a football game. About to be expelled, a member of the schoolboard helped him and his chum to have access to a laboratory to expand their experiments in chemistry. At college he pursued chemistry and had an ardent but disappointing love affair with Patriela Chappel; ho was dismised because of too many cuts. He wont to Ruth Buzzini, his former high school art teacher, who wes with an art colony. He was informed of his father's death. He and Futh eventually became intimate; he finally returnod to Hew York, to find his mother had mored to Iong Island. He obtained work with desaltory results. He embarked on a merchant ship; in Iondon he met Doris Montagne, a writer. Baok in Hew York, an editor, Mr. Malcolm, interviewed him about his Uncle Robert with the intention of 
publishing his works. He married Doris, and gave up painting for chemistry.

Ind of Rosming is biographical and emphasizes the ohoice of a profession, the youth shifting from interest in chemistry to art and back again to chomiatry.

Robert Piper embarrassed his family becanse he drank and associated with the town rowdies. He read Don Juan in church and seduced the parson's deughter; he is steered straight by his instructor and friend, Mr. Bandparts. Bthel, hiø sedate and secretive sister, has a romance with a married man, but suceeeds in winning Dr. Niven from hor sister, Hetty, and marrying him.

Brery Mother'B Son emphasizes the escapades of Robert Piper and oI his sedate sister, Ethel.

Other Man's Saucer

J. K. Winter (-.--)

Shaw Latimer is shocked at his sister Sadie' misconduet, saddoned by his brother Mec's death, and is lonely at college. He accepted Priendship without giving it. He enslared Tony, hindering him from his work and was criticised by John, another student, for his bad handling of Tony; he won Tony's girl secretly. Orm Iind, an athlete, got on his nerves at college, followed him home, and mot Yolande, whom Shaw wished to marry. Sham saw him kiss her, became infuriated, and tried to drown him, but barely oscaped drowning himself.

Other Man's Saucor is blographical and omphasizes the domination of a jouth orer his companions at school and at home.

Over John IIttlepage, scion of an aristocratio sonthorm family, a mysterious doom hangs from his birth. The ghost of the mythological ErI KIng haunts him, and follows him when he takes his sweetheart, Ellen clyde, over the reefo in a sail boat. The story ends with the tragic death of 
hero and heroine. Its sotting is the southern part of Florida.

Brl KAng is partly blographical and portrays the IeeIrigg of being haunted by the Brl King and the tragic end of the youth.

1931 Leaf te Groen J. V. Cravon (1889-)

Dan was expecting Iols for the game. She came, and announced that she was going to be merried. Dan drank and was expolled from Prinoeton for drinking and teling a lie to shield his companion. On his way hom he ploked up Vickie and took her to Ner York for a fer days. At home, he told his uncle he did not want to go to work but wanted to spend the sumer at Fawn Lake. There he mot a girl who looked like Lo1s, and courted her; he hod a light love affair with Ellon, then with Catherine. All the time he was hoping to ser Iois. At the ond of the summer sho came, acoompanied by her husband; their meeting was brief; after she left he told his ancle he was ready to return to 80 to mork.

Ieaf is Green foatures the fruatrated love aftair o a young man and his change of attitude-a desire to go to work--after meeting the girl as the wife of another man.

1931 Gospel Aocording to St. Luke's Ph1lip Sterenson (1896-)

Fthelbert Speed wos afflicted with an inferiority complex and with on impodiment in speech whon be was sent away to St. Iuke's boording sohool alone. On the train he met lony Stone and his father, who took him in charge. At the school he was nicknamed "Ethel," but by degrees he won the friendship of his group; "Spoed" was substituted for "Bthel, "and he played well in athletics. His most outstanding accomplishment was to participate in a ohapel debate on student government. Then he graduated he received a reward for outstanding achlevement. He entered college; his mother remarried, his gister became engaged, and he decided to join the army. 
Th1e norel omphesizes the onfolding and successful accomplishments of youth in a boarding school.

1938

In Pragio Iife

Vardis Fishor (1895-)

For the analysis of this novel see Chapter IV, p. 85.

1932 Young Iond 8 an James T. Farrel1 (1904-)

For the analysis of this novel seo Chapter V, p. III.

1932 Flogh is Heix Iincoln Kirgtern (1907-)

This novel 18 made up of a serles of opisodes In the life of $a$ boy and young man during the 1920's. The first opisode deals with lifo in a boJ's boarding school, the others with experienoes in Paris, and Venice, as a worker in a stained glass shop and at collogo. Roger baum is an sffluent Jow, sensitive, shy, and very impressionable.

This norel is blographical, recording the reactions of a Jowish boy to the opisodes of his 1110.

1932. Tomard Romance Rollo Falter Brown (1880-)

The youth of this novel dreams of a more romantic world than he finds in an Ohio mining district. He eventualig realizes the beauty of living oven in sordid surroundings. Ho finaliy set out to discorer what the world 18 like outside.

Toward Romance records the reactions of a youth to his mining town onvironment, resulting in a desire to explore the ontside world.

1934 Young Manhood of Studs Ionigan James T. Parrell (1904-)

This norel is a sequel to Young Lonigen and continues the biography of Studs Loñgan. Studs, Red Kelley and Kenny eat bananas to increase their wolght so that they would be accopted in the marines, 
but are rejected. Studs envisions himself as a daring captain; he joins the crowd in colobrating when the armistice is signed. Other opisodes are that he stages an amateurish holdup, g0es to work for his father, meets Elizabeth Burns in the park and 18 chased by the girl's father. Paulie Haggerty dies, and Studs, foaring dath, goes to confession. The gang visited a dence hall of 111 fame and teased vince curley, who was girl ghy. Studs at tonds Frances' - orority dance, taking lucy Scanlan and is rebuffed by lucy because of his adrances. The Ionlgans move becanse the negroes are taking the neighborhood. On New Years the gang gets together to celobrate; drinking, 11ghting, and sex indulgence ensus; studs is found next morning on the siderelk in the snow and 18 taken to the hospital, where it is discovered be has proumonia.

This notel continues the blography of Studs Lonigan dealing with the joars of young manhood.

1934 Yon Can't Go Home Again Thomas Volfo (1900-1938)

George Weber records his love effalr with Esthor Jack, a scenery designer. He publishes his first novel, Home to our Mountains, and rocords the bitter reaction or his home town. When he breaks with Esther he goes to the Brooklyn and 11 res in seclusion far sereral years, writing another novel. To avold the unpleasantness that might accompany its publication he goes abroad again. The book meots with pablic approval and has a good sale. In fingland he records his exporiences with his housekeoper, Daisy Purvis, and with the anthor, Iloyd MoHarg. At the ond he writes to his oditor, oxplaining the necessity of a change of oditors. In his commentary he explains that his firat novel was not the work of an embittered young writer, 8s mang supposed, bitter because of his experiences at college, where he was implicated in the death of a follow student by hazing, and suspended, but later reinstated.

You Can't Go Home Again continueg the antobiography of Thom wolte after his return to 
Amorloa from Europe, featuring his love affairs and the pabilications of his first two novels.

1934 Paseions Spin the Plot Vardis Pisher (1895-)

This novel is a sequel to In Pragic Iifo and is autoblographical. Vridar goe to asatch College in selt Iake city and rooms with stanloy Trout. They quarrel and he makes friends with A. 11. McClintock, who seduces most of his girl friends. Vridar discovers his fear of womon. He works as clerk in a grocery store, and is fired becanse his honesty incurs the dislike of the other clerks. During his vacation he confessed his love for Noloe, became engeged to her and spent the sumer quarreling with her. The next year, he, Mortyl, and Mccilntock ongaged in drunken brawls and triakery. Vridar leamed to dance, and enlarged his experfence with women. During h1s second vacation he married Neloa.

Passions Spln the Plot continues the antobiography of vardis Fisher during his first two jears of college, emphesizing his young manhood, his ongagement, and marriago.

1934 Iost Paradise Robert Pristram Coffin $(1892-)$

Poter Finship goes to school in town. H1s visit home delajed a reek, ho lives in his imagination every detall of life on the belored farm. When he again visits the farm, he realizes the pieture is connected with his childhood, and that now it has changed; ho has loft his chlidhood behind him.

Lost paradise portrays a boy's dream of the beauties of his farm home and life.

This novel is the third of the Studs Lonigen trilogy. The gang are on the train returning Irom Indiane whore they have attended shrimp Haggerty's Iunerel. Stude has to watch his hoalth; he proposes to Catherine when he reaches home. He secretig bugs stock with his sevings and is 
discouraged whon it falle. Iorette hes marriod Ph1l Rolpho, who is a book-maker; Frances has also married. The depression is on, and the stock continues to fall. The father tolls studs he may noed a loan; Stude does not tell him of the stock. Studs joing the order of Chrieties so as to get insurance; his father asks for the loan and first learns of the stock; he is disappointed. Studs has a hemhorrhage on the beach with Catherine, now pregmant. The doctor tells him he most give up painting; ho trampe in the roin all day looking for work; in the orening he stumbles home 1il, and dies.

Judgment Day continues the biography of Studs Ionigan Into adulthood until his death, featuring the disastrons results of his libertine life.

1935 Of T1me and the R1ver Thome Wolfo (1900-1938)

Fugene Gant attends Harvard, renows his acquaintance with his Unole Bascom and his Ant Loulse, two eccentric, interesting characters. He moots and makes friends with Philip Strrwick, an intellectagl, and 1nstructor at Harvard. He accepts a position teaching at the University of Iow York, but finds it tedious. Ho vieite a wealthy co-student at Hervard and records his impressions of the vastly wealthy. Getting leave of absence from the university, he goes to Europe, atags for a time in Bngland, bat does not make friends; in paris he meets Starwick with his two women companions and makes nightly rounds of cafes with them. The four are plaming a trip When quarrels ensue. He returns to paris, and thence home.

Of Time and the River, the autoblographical sequel to Look Homewerd Angel, continues the story of Eugene Gant through Hervard University and to the ond of a trip to Europe.

1935 We ere Betrayed Vardis pisher (1895-)

This is the sequel to Passions Spin the plot. Vridar Hunter and Neloa go to SaIt Lake CIty, where Vrider attends the university. He goos out for football and makes the team. During the jear ho enlists in the ariation division of the army 
and is sent to California. Feeling his inferlority in ability to bay uniforms and grasp the meaning of mechanies, he asks for $a$ discharge and receives one. Iater he is drafted; Mertyl enlists with him, and they again are sent to California; the armistice is signed before they go across. Back home, he helps manage his father's garage, ran a taxi, ana bootleg. He decides to return to salt Iako city and finioh college. After craduation he is offered a position teaching in the college if he attends summer school at Chicago. Quarrels ensue between him and Neloa, he meets Athene Marvel, becomes infatuated with her, and plans to leave Nelos. The latter, aware of his intention, comits sulcide.

Te are Betrayed, the third of Vardis Fisher's tetralogy, 18 antobiographical and continues the story of Vridar Hunter through college till the death of his first wife.

The youth in this novel suffered under educationsl theories of two men, his father and his uncle, after his mother's death. He rss almost incapable of making his own way when he reached prep school, but finally gained his independenco.

Louder than words is biographical and hinges on the queer edpoational theorles of an uncle.

John, a growing boy, reflects the experiences of his Uncle charlio, a handsome man married to a delicate wife. One of his uncle's experiences was the seduction of a joung girl, Ardista, working for his wife. The girl diod, and charlio settled with her father for money. Another, more difficult to handle, was the rapo of Virginia Crannock, a mature spinster. To mave her reputation, although she had kept calmly silent about it, she had Charlio prosecuted. charlio troated the case lightly at first, but it ended in a penitentiary sentence for him; however, he hoped to be pardoned by the governor. 
John left for school; he was leeving his adolescence behind, and he knew thet when he returned, he would be a different pereon.

Lot of Darkness fertures the sensetional rapo of 8 mature woman and the trial of the aggressor, with the youth es observer.

Chenge of Idore J. T. Foote (1881-)

The youth is taken to the coast to Pish with his father and uncle. The girl at the lodge allows him to caress her. He prefers to 8 taj around the lodge, hoping for a fer minates with the girl, to fishing. one day, when the weather is favorable for fishing his father makes him go out. It is the day the girl hes promised to walk through the wood with him. He catches a large fish and 18 so completely absorbed in his adventure he forgets the girl completely.

Chave of Idols 1llustrates diversion of an adolescent's Interest in sex by replacing it with interest in fishing.

1935 Rod sky in tho Morning R. P. Coffin (1892-)

The novel is the story of will prinoe whose ancestor had been sea captains for generations. His boyhood was spent on a barren 1siand, to which his father had moved because of needless jealousy of his wife. When David, his father's ferorite son, died, Eill went with his mother to the malniand to live in the old Prinoe home. He became his mother's guardian. When his father's cousin epparently became enamoured with Ure. Prince, and she seemed to return the affection, Will took the relatire out to sea on a windy dey: the bost was capsized and they were both arowned.

Red Sky in the Morning is biographioal and features youth Joalous guardianshlp over his mothor, onding in a tragedy.

1936 World I Never Hade James T. Farrell (1904-)

This is the first norel of the Danny o' reill series. Danny starts to school, but does not 
Iike it. Mrs. O'Plahorty, on a visit to sec I1zz O'Ne1II's new baby, Catherine, Informs her thet Iarry Robinson, Margaret O'Plehorty's married saitor, is in town. Margaret meets Iarry at a hotel, tolls him of her shortage of one hundre twenty-fire dollars at the hotel, and receives some money with a promise to get more. At the O'Flsherty's, Bill steals Margaret's emerald ring and cigarettes, skips sohool the next day, sells the ring, and meets with an accident. Margaret accuses Bill and fights with her mothor. The O'Neills roceive three hundred fifty doliars from the accident and plan a big Christmas colebration.

This is an autoblographioal novel and treats the early years of Danny $0^{\prime}$ Nolll until ho is roady to start to school, emphasizing the famlly baokground.

No Villain Nood Be

Vardis Fisher (1895-)

This is the last of Fisher's tetrelogy, atarting with In Tragic Iife. Neloa had committod uiolde. Vridar and Athono left Chicago for Washington. Vridar approachod insanity because of Heloa's death, but ovaded it. In wahington ho finiahod his thesis for $\mathrm{Ph}$.d., returnod to Chloago and obtained his degree. He obtainod a position at Wesatch College, but later resigmed bocause his freodom of speech was hampered. Ho went to Now York and taught in the univergity there. He and Athene were married, he resigned his position, and returned to Idaho to write and to be with his aging parente and his sons.

Io Viliain Heed Be is tho fourth autoblographicel novel of verdis Pisher's tetralogy, and portray Vridar Hunter' life after the death of his firet wife, omphesizing his reaction to her death and his experiences as college professor.

1936 Rider in the sun E. Ware (1900-)

Dan ran away Irom his home in pursuit of hia 1deal--a strong men on horse--the rider in the sun. He met the replica of his droam on western ranch but discovered him to be a horse thief. second quest cost him his arm. He returned to his eastern hom satisiled. 
R1der in the Sun portrays a boy's experiences in the west in search of his ideal, the rider in the sun.

$1936 \triangleq$ Tree Grown Straight Poroy Marks (1891-)

In the prologne the anthor introduces Perry Lane, a famous novelist haunted by an undereloped 1dea for a story, and Andrew Ross, a totaliy undistinguished, but very likable joung American business man. In ROBs, lane seos the oharecter ho has long wished to portray and the story that follows is the story of Andrew, his wise and loving parents, and the ways in which they labored that the tree should grow straight. Andy makes a confidant of his parents; his fathor explains $60 x$ to him and his Iriends, and his mother helps him to adust his love affairs.

A Tree Grown Straight is biogrephical and

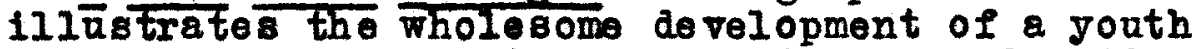
in a home environment of 10re, truet, and guidance.

1936 Flamethrowere Gordon Friosen (1909-)

Poter Franeman came with his mother and father as refagees from Russis. In oscaping, his littlo brother, Joseph, was drowned. The mother alwaya hated poter afterward. In their now home in Kansa, Jacob thrived and becam grasping. Therese, the mother, and old Ilese tried to force Peter into the Henonite church, but he would not be forced. He was alert at school and went to college, attending Fenrow's college at Honerovia City. Here he won the friendehip and understanding of Duan Terrison, history instruotor. Both parents died poverty-stricken; Peter, alone except for his brother, David, wont to Duene Terrison. Throughout the novel the youth is haunted by the terrible oges of the guide who smuggled them out of Russia.

Flamethrowers is biographioal and foetures the dovelopment of a Russian born youth in Kanses in the face of mother and community antagonism. 
1936 Springstorm

Alvin Saunders Johnson

(1894-)

Julian' life had been one of wanderings when they settled in the wost. He learned the elements of farming. He bocame involved with a noighbor's

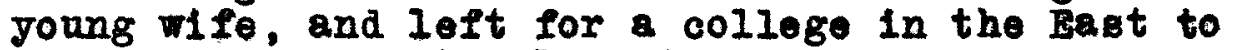
escape worse entanglement.

Springstorm combines the experiences of farming in the wost young married woman and a jouth.

1937 The Running of the Deer Dan Fiokenden (---)

Bvents take place during Christmes woek. Mel's moterious Unole Christopher appears for Christmas; the father $1080 \mathrm{~h}$ hs job. The uncle solves all thoir probleme by arranglng to have his sister, Miriam, buy the house, the parents take a trip abroad, Ada marry him, Mel accompany them to callfornia, and Fred go back to collogo.

This novel ouphesizes the opisodes of a family during Christmes week and the successful solution of the problems encountered.

1937 A Iamp on the Plains Paul Horgan (1903-)

This novel relates the story of Danny Milford'g adolescent years in a littlo san-baked town in How Mexico--Danny's friendship with Newt Jimson, his experiences as protege of the Professor DubyeDubye, and his experiences on the ranch as protege of Mr. McGraw.

A Lamp on the Plaing explo1ts Denny Milford's adolescent experiences in the west.

1938 No Star if Lost James T. Farrell (1904t)

This novel is a sequel to A Morld I Herer Made. Bill had stolen some money from his aūnt largaret. He treated Denny and two other Bchool chums--took them to the penny arcede, bought them refreshments, otc. One of the favorite gamos the Fifty-Bighth Street gang played was to go into an ice cream place, order refreshments, and when served, curse the proprietor and dart out the door. When it 
came Danny's time to go, he Was afreid: B111 called him jellow and a "punk." He went, but on his way out, tripped and fell. The proprietor canght him and B1II and held them antil the grandmother came and paid the bill. The 0'Ne111. contracted ilphtherie, and IIttle Artio died becanse no doetor Fonid come. Danny did not like to stay at tho O'He111's; he wes afraid of his papa, and bed bugs annoyed him.

Ho Star is Iost is the blographioal sequel to A World I Nover IBde and continues the story of Danny o iveliIs IIte from the time he entere gchool antil he is about eleven years old.

Hell1 Giass mores with his mothor, Jenny, to AtIanta, Georgia, to join his father, Alec, who 18 undependable as a support to the family. Jenny, who writes es a hobby without pablishing her work, encourages Neill to keep up his art in the face of adverse circumstances. He studies under Mrs. Mercer, who dies; through her influence he neets the othar artists of the oity. Various accuaintance tell him he w11l have to leave Atianta if he rants to beoom a worthwhile artist; he IInds they are right, broke his engagemant with Gena and left for Now York to work with J. Mone111, a celebrated artist.

Fox in the Cloak portrays the 11 fe of rell1 GIess, Fifted in art, from beginning high wohool unt1l he 18 in his eerly twenties and omphesises the struggles of his family, especially his mother, and his pursuit of art.

Inn of that Joorner

Emerson Price (----)

Mark Culien, son of a supervisor of schools, mover to Scatterfield and becomes the friend of Soepy Dodger Pendleton, town ruffian. Under his influenee he becomes a participant in upsetting human filth on a school-board member's porch and a look-out for Soapy while ho sterls tobacco from John Delaney's store. Soepy Was finally sentenced to reform school, but esceped on a freight. The Cullens left seatterfield; when rark returnod he found a monument erected to soapy for his herolo 
porformance in the war; other members of the gang had met with misfortano.

This novel features the youth's association with a gang of ruffians through his high school yoars.

1939 Abel Darton

Flannory Low1s (1913-)

Abel Dayton lived with his father, John Dayton, and his assistant telographer, Charley, at Slatewater Hollow, near Farley, Lalifornia. As a youth he loved to fly kites; they gave him his theory of rising cerrents in the air, which interosted him later in airplanes. Ho attonded high sohool in Farley, riding a froight in with charley. One day he slipped and foll from the train; an amputation eost him his foot. His father died from hard drink, and Abel docided to become an aviator.

Abel Dayton is the biographloal account of a youth reared by two men in a wostern town, crippled, and left alone at the death of his father to shuffle for himself. He deoided on ariation a fitting and desirable purtait.

The Long Iane

Philip stong (1899-)

Kenneth Brubacker'g mother deserted him and her husband to go to California with Kennoth's uncle, Merritt Brubacker. He lived on at the farm with Ioe and Ariel, caretakers. His father went to Des Molnes where ho establishod a business and made friends with an actress, G1lda Morissey; Kenneth liked hor very muoh and made her his confidant. His mother returned but was disatisfied and did not remain. Gilda persuaded the father to visit the farm to please Kenneth; the couple later married. The long lane was a stretoh of rosd in which Konneth made a great many docisions, going to and from sohool.

The Long Lane is a biographical novel of a boy Who had to adjugt himself to the 1089 of both parente due to the mother's desertion of him and his father. 
1940 Halk Iike a Nortal Dan Hokendon (---)

Gabe'g mother, uargaret, mot an old friend, Charlie Cobalen, at their summer cottage. Bascinated by his vealth, she enjoyed many excursione with hil. Retarning homo she continued this friendehip. A rift betwoen mother and father ocourred; and the mother wont to work. The son had admired her greatly; finally she deserted the boy and the fether, and the $y$ went to 11re with Uncle Henry's family; they orentually were absorbed by this large femily, and contentment reigned. The mother returned, but Gabe's feeling had changed toward her; sho Iinaliy decided to marry Charl10, to the relief of all.

Talk I1ke a Mortel features the mother's desertion oI the Iather and the youth's readjustment of his 11fe, transferring his affection for his mother to his father's relatives.

The canzon

Peter Viertel (1920-)

The canron is a norel told in the first person of the activities of a gang dominated by a cruel Mexican boy. One of the cotivities was to sell splked orange fuice on the side of the rosd until stopped by authorities. One of Keetchejo's oruel acts was to force one of the members to owim until he was about to arown when rescued; enother was to shoot a member in the $10 \mathrm{~g}$. The hero made friends with Perfecto, a Mexican. He worked for Jenkins, a real estate agent, who was bent on getting the Mexicans' property; ho befriended the Mexioans to the extent that they outwitted Jenkins; the rains oame and recked the Mexican viliage; Jenkins obtained the land in epite of their efforts to sate 1 t.

The Canyon features a gang led by a cruel Mexicen and youth's efforts to save a Mexican village from a real eatate exploiter. 